ANNELITA ALMEIDA OLIVEIRA REINERS

\title{
Interação profissional de saúde e usuário hipertenso: contribuição para a não-adesão ao regime terapêutico
}

Tese apresentada ao Programa de Pós-Graduação - Área: Enfermagem Fundamental do Departamento de Enfermagem Geral e Especializada da Escola de Enfermagem de Ribeirão Preto - Universidade de São Paulo, para obtenção do título de Doutor. Linha de Pesquisa: Processo de Cuidar do Adulto com Doenças Agudas e Crônico-Degenerativas.

Orientadora: Profa ${ }^{\text {. Dra }}$. Maria Suely Nogueira

$$
\text { Ribeirão Preto }
$$


Autorizo a reprodução e divulgação total ou parcial deste trabalho, por qualquer meio convencional ou eletrônico, para fins de estudo e pesquisa, desde que citada a fonte.

FICHA CATALOGRÁFICA

Reiners, Annelita Almeida Oliveira.

Interação profissional de saúde e usuário hipertenso: contribuição para a não-adesão ao regime terapêutico./ Annelita Almeida Oliveira Reiners; orientador Maria Suely Nogueira. — Ribeirão Preto, 2005. 156 f.: fig.

Tese (Doutorado - Programa de Pós-Graduação em Enfermagem Fundamental. Área de Concentração: Processo de Cuidar do Adulto com Doenças Agudas e Crônico-Degenerativas) — Escola de Enfermagem de Ribeirão Preto/ USP.

1. Interação profissional de saúde / usuário 2. Hipertensão arterial

3. Adesão ao regime terapêutico 4. Não-adesão ao regime terapêutico 
Tese desenvolvida com apoio do Conselho Nacional de Pesquisa (CNPq) sob a forma de bolsa de estudo 


\section{FOLHA DE APROVAÇÃO}

Annelita Almeida Oliveira Reiners

Interação profissional de saúde e usuário hipertenso: contribuição para a não-adesão ao regime terapêutico.

Tese apresentada à Escola de Enfermagem de Ribeirão Preto - USP para obtenção do título de Doutor.

Área: Enfermagem Fundamental

Linha de Pesquisa: Processo de Cuidar do Adulto com Doenças Agudas e Crônico-Degenerativas.

Aprovado em:

Banca Examinadora

Prof. Dr.

Instituição: Assinatura:

Prof. Dr.

Instituição: Assinatura:

Prof. Dr. Instituição: Assinatura:

Prof. Dr.

Instituição: Assinatura:

Prof. Dr. Instituição: Assinatura: 
Ac Senbar Jesus

A minha mãe è à memória de meu pai

Ao Tinimbo, wo Lucas e wo Mateus 


\section{Agradecimentos}

Aos enfermeiros, médicos, técnicos e auxiliares de enfermagem que participaram desta pesquisa, pela colaboração e boa vontade.

À professora Suely Nogueira pela atenção e ajuda.

Às amigas Luce Marina, Sonia e Anna Lucia pelas importantes contribuições a este trabalho. 


\section{RESUMO}

REINERS, A. A. O. Interação profissional de saúde e usuário hipertenso: contribuição para a não-adesão a o regime terapêutico. 2005. 156 f. Tese (Doutorado) - Escola de Enfermagem de Ribeirão Preto, Universida de de São Paulo, Ribeirão Preto, 2005.

Os objetivos desta pesquisa foram: compreender a perspectiva do profissional de saúde e do usuánio hipertenso sobre a interação que ocorre entre eles no contexto da atenção em unidades públicas de saúde e analisar de que forma essa interação contribui para a não-adesão ao regime terapêutico. A metodologia aplicada para o desenvolvimento do estudo foi a Teoria Fundamentada nos Dados e o referencial teórico utilizado para a a nálise dos dados e interpretação dos resultados foi o Interacionismo Simbólico, além da literatura existente sobre o assunto. Ao todo, quinze profissionais de saúde e dez usuários fizeram parte da pesquisa. Ao final, foram encontradas seis categorias (duas delas, centrais) e outras subcategorias as quais, depois de um processo elaborado de comparações, relações e integração compuseram a proposição teórica que a autora fez sobre a interação entre o usuário e o profissional de saúde e da qual extraiu elementos para analisar a contribuição que essa interação tem para a não-a desão a regime terapêutico. A autora concluiu que a interação, por ser pautada no modelo biomédico, centralizada no profissional de saúde, desigual, assimétrica e distanciada, tem elementos que podem estar contribuindo para a não- adesão do usuário ao regime terapêutico. Concluiu ta mbém que a principal ação que o profissional de saúde utiliza para promover a adesão do usuánio ao regime terapêutico - a conscientização - tem sido ineficaz uma vez que se baseia no modelo tradicional de educação em saúde e no qual o usuário não é considerado como sujeito. Outra conclusão é a de que o usuánio, por estar administrando o regime terapêutico à sua maneira, tem feito indicações ao profissional de saúde sobre sua forma de ver, entender e conviver com a hipertensão arterial e o regime terapêutico que nem sempre é congruente com o que o profissional de saúde quer e espera dele. Esta pesquisa aponta para a necessidade do profissional de saúde e outras instâncias políticas de decisão repensarem a interação profissional / usuário nos moldes que tem acontecido atualmente e para a necessidade de mudanças no modo de pensar e agir em relação ao usuário e com ele.

Palavras-chave: Interação profissional de saúde / usuário, hipertensão arterial, adesão ao regime terapêutico, não-adesão ao regime terapêutico 


\section{ABSTRACT}

REINERS, A. A. O. Health professional and hypertensive health senvice user interaction: contribution to the non-adherence to the therapeutic regime. 2005. 156 f. Thesis (Doctoral) - Escola de Enfermagem de Ribeirão Preto, Universidade de São Pa ulo, Ribeirão Preto, 2005.

The aims of this research were to understand the perspective of the health professional and the hypertensive user about the interaction that occurs between them in the context of the service in health units and to a nalyze how this interaction contributes to the non-adherence to the therapeutic regime. The methodology applied for the development of the study was the Grounded Theory and the theoretical reference used for the analysis of the data and interpretation of the results was the Symbolic Interacionism, as well as existing literature on the subject. In all, fifteen health professionals and ten users were involved in the research. At the end, six categories were found (two of which were central) and other subcategories which, after an elaborated process of comparisons, relations and integration composed the theoretical proposal that the author made about the interaction between the user and the health professional and from which some elements were extracted in order to analyze the contribution that this interaction makes to the nonadherence to the therapeutic regime. The author concluded that the interaction, being based in the biomedical model, was centered in the health professional, was unequal, asymmetric and distant, and has elements that could be contributing to the user non-adherence to the therapeutic regime. It was also concluded that the main action that the health professional uses to make the user adhere to the thera peutic regime - making the user a ware of it - has been ineffective because it is based on the traditional model of health education in which the user is not considered individually. Another conclusion is that the user since he is managing the therapeutic regime in his own way has made indic ations to the health professional of his way of seeing, understanding and dealing with the arterial hypertension and the therapeutic regime that is not always congruent with what the health professional wants and expects of him. This research points to the necessity of the health professional and other policy-making forums to rethink the health professional/user interaction in the molds that have happened currently, and for the necessity of change in the way of thinking and of acting in relation to and with the user.

Key words: Health professional/user interaction, arterial hypertension, adherence to therapeutic regime, non-adherence to therapeutic regime 


\section{RESUMEN}

REINERS, A. A. O. Interacción profesional de salud y usuario hipertenso: c ontribución para la falta de adhesión al régimen terapéutico. 2005. 156 f. Tesis (Doctorado) Esc ola de Enfermagem de Ribeirão Preto, Universida de de São Paulo, Ribeirão Preto, 2005.

Los objetivos de esta investigación fueron: comprender la perspectiva del profesional de salud y del usuario hipertenso sobre la interacción que ocurre entre ejes en el contexto de la atención en unidades de salud y analizar de que modo esta interacción contribuye para la falta de adhesión al régimen terapéutico. La metodología aplicada en el desarrollo del estudio fue la Grounded Theory y la referencia teórica usada para el análisis de los datos y la interpretación de los resultados fue el Interaccionismo Simbólico, además de la literatura existente sobre el asunto. Al todo, quince profesionales de salud y diez usuarios hicieron parte de la investigación. Finalmente, fueron encontradas seis categorías (dos de ellas, centrales) y otras subcategorías las cuales, después de un proceso elaborado de comparaciones, relaciones e integración compusieron la proposición teórica que la autora hizo sobre la interacción entre el usuario y el profesional de salud y de la cual extrajo elementos para analizar la contribución que esa interacción tiene para la falta de adhesión al régimen terapéutico. La autora concluyó que la interacción, por ser pautada en el modelo biomédico, centralizada en el profesional de salud, desigual, asimétrica y distanciada, tiene elementos que pueden estar contribuyendo para que el usuario no adhiera al régimen terapéutico. Concluyó también que la principal acción que el profesional salud utiliza para hacer que el usuario adhiera al régimen terapéutico - hacer con que el usuario tome conciencia - ha sido ineficaz una vez que se basa en el modelo tradicional de educación en salud y en la cual el usuario no es considerado como sujeto. Otra conclusión es la de que el usuario por estar administrando el régimen terapéutico a su manera, ha hecho indicaciones al profesional de salud de su forma de ver, entender y convivir con la hipertensión arterial y el régimen terapéutico que ni siempre es congruente con lo que el profesional de salud quiere y espera de él. Esta investigación apunta hacia la necesidad de que el profesional de salud y otras instancias políticas de decisión repiensen la interacción profesional / usuario en los moldes que viene sucediendo actualmente, y para la necesidad de cambios en el modo de pensary reaccionaren la relación al usuario y con él.

Palabras-clave: Interacción profesional de salud / usuario, hipertensión arterial, adhesión al régimen terapéutico, falta de adhesión al régimen terapéutico 


\section{USTA DE SIGLAS}

AVC Acidente VascularCerebral

AVE Acidente Vascular Encefálico

CEP.....Comitê de Ética em Pesquisa

CNS Conselho Nacional de Saúde

CBHA Consenso Brasileiro de Hipertensão Arterial

DBHA Diretrizes Bra sileira s de Hipertensão Arterial

HA Hipertensã o Arteria I

IAM Infarto Agudo do Miocárdio

INSS Instituto Nacional de Seguridade Social

JNC J oint National Committee

MS Ministério da Saúde

OMS Organização Mundial da Saúde

PA Pressão Arterial

PAD Pressão Arterial Diastólica

PAS Pressão Arterial Sistólic a

RT Regime Terapêutico

WHO World Health Organization 


\section{SUMÁRIO}

PARTE 1 - O PROBLEMA DE PESQ UISA 13

1.1 Hipertensã o Arterial 13

1.2 Adesão / Não-Adesão ao Regime Terapêutico 22

1.3 Interação Profissional de Saúde / Cliente 28

PARTE 2 - OBJ ETIVOSDA PESQ UISA

PARTE 3 - METODOLOG IA DA PESQUISA

3.1 Interacionismo Simbólico $\quad 35$

3.2 Teoria Fundamentada nosDados 41

3.2.1 Obtenção dos dados 42

3.2.1.1 Local de obtenção dos dados $\quad 42$

3.2. 1.2 Instrumento de coleta de dados 44

3.2. 1.3 Proced imentos éticos 45

3.2. 1.4 Estudo piloto 45

3.2. 1.5 Participantes da pesquisa 46

3.2. 1.6 Coleta dos dados 48

3.2.2 Tratamento e análise dos dados 48

PARTE 4 - PROPOSIÇÃO TEÓRICA

4.10 contexto da interação 57

4.1.1 Perspec tiva do usuário sobre a interação com o profissional de saúde $\quad 57$

4.1.20 vínculo 60

4.1.3 O profissional de saúde na perspectiva do usuário 63

4.1.4 Ações do profissional de saúde na interação 67

4.1.5 Ações do usuário na interação 70

4.1.6 O manejo da hipertensão arterial 74

4.1.6.1 Más condições de trabalho 74

4.1.6.2 Tipologia do usuário 76 
4.1.6.3 A percepção do problema $\quad 80$

4.2 Razõespara conscientizar 82

4.2.1.A concepção de regime terapêutico 82

4.2.2 A concepção sobre a adesão ao regime terapêutico 84

4.2.3 Responsabilidade com a adesão ao regime terapêutico 85

4.2.4 Usuário que não adere - paciente de risco 87

4.3 Conscientiza ção 90

4.3.1 Tarefa difícil 90

4.3.2 A concepção 95

4.3.3 Formas de comunic ação 96

4.3.4 Sempre, sempre, sempre 97

$\begin{array}{ll}4.40 \text { usuário na interação e fora dela } & 100\end{array}$

4.4.1 A hipertensão arterial e o regime terapêutico: conhecimento e $\begin{array}{ll}\text { aprendizado } & 100\end{array}$

4.4.2 Signific ado do regime terapêutico e da adesão 104

$\begin{array}{ll}\text { 4.4.3 Percepção de risco e cura } & 108\end{array}$

$\begin{array}{ll}\text { 4.4.4 Espectro do risco } & 109\end{array}$

4.4.5 Responsabilidade com a adesão a o regime terapêutic o 111

4.5 Administrando o regime terapêutico à sua maneira 112

$\begin{array}{ll}\text { 4.6 Efeitos } & 115\end{array}$

4.6.1 Reações do profissional de saúde $\quad 115$

4.6.2 Caracterização do usuário 119

$\begin{array}{ll}\text { 4.6.3 Responsabilidade pela não-adesão } & 121\end{array}$

$\begin{array}{ll}\text { PARTE } 5 \text { - DISC USSÃO } & 126\end{array}$

PARTE 6 - CONSIDERAÇÕES FINAIS 141

$\begin{array}{ll}\text { REFERÊNCIAS } & 143\end{array}$

$\begin{array}{ll}\text { APÊNDICES } & 153\end{array}$

$\begin{array}{ll}\text { ANEXO } & 156\end{array}$ 


\section{PARIE 1 - O PROBIEMA DE PESQUISA}

\subsection{HIPERIENSÃO ARIERIAL}

Desde a metade do século $X X$ até os dias de hoje, quando entramos em um novo século, intensas transformações econômicas, políticas, sociais e cultura is têm ocomido no Brasil a ponto de modificar as caracteństicas da população e o seu perfil epidemiológico. Constatou-se aumento demográfico, particularmente da população idosa, devido à redução dastaxas de mortalidade infantil e matema, à diminuição do número de mortes por doenças infecciosas e à queda das taxas de fecundidade e natalidade. Além disso, as condições de vida e saúde da população, de um modo geral, melhoraram. No entanto,

[...] as graves disparidades macro e micro regiona is, no interior do país, o crescimento de problemas como a violência e as doenças e agravos à saúde de origem ambiental e ocupacional, o reaparecimento de velhos problemas como o dengue e a cólera, a persistência das grandes endemias (doença de Chagas, esquistossomose, malária, etc.), o envelhecimento populacional, etc., ao lado de uma crise generalizada do sistema de assistência à saúde, com uma demanda crescente e insa tisfeita, evidenciam os contrastes com as melhorias alcançadas[...] (BARRETO; CARMO, 1994, p. 7).

Neste contexto, as taxas de morbidade e mortalidade por problemas crônicos de saúde têm aumentado, o que vem acarretando importantes conseqüências na qualidade de vida e saúde da população adulta brasileira.

Problemas crônicos de saúde, denominados por Lessa (1994, p. 269-270) de doenç as crônic a s não-tra nsmissíveis, são:

[...] um grupo de doenças com história natural prolongada, caracterizada por: multiplicidade de fatores de risco complexos; interação de fatores etiológicos desconhecidos; longo período de latência; longo curso 
assintomático; manifestações clínicas, em geral de curso crônico, com períodos de remissão e exacerbação e evolução para incapacidades.

Estão neste grupo, os problemas cardiovasculares, o diabetes, os cânceres, dentre outros. São problemas de saúde que, durante algum tempo, pensou-se acometiam somente as pessoas de idade avançada e que eram mais freqüentes em ricos e sociedades mais desenvolvidas. Sabe-se hoje, no entanto, que estes problemas podem ocorrer em qualquer etapa da vida e suas taxas estão presentes numa proporção significativa em sociedades subdesenvolvidas e em desenvolvimento, principalmente entre os pobres (WORLD BANK, 1989).

Tais problemas de saúde têm provocado impacto social importante na medida em que são responsáveis por alto índice de incapacidades e/ou invalidez demandando cuidados específicos cuja responsabilidade recai não somente sobre a pessoa e a família, mas também sobre o país, devido aos gastos públicos com intemações, tratamentos especializados, reabilitação, licenças médicas, aposentadorias precocese pensões.

De outro modo, a situação das doenças crônicas é preocupante ao constatamos que muitas das suas conseqüências, tanto de ordem física quanto social, podem ser amenizadas com medidas de promoção e prevenção da saúde que, infelizmente, no Brasil, até recentemente não eram prioritárias nas políticas de saúde. Segundo Lessa et al. (1996), alguns dos programas nacionais criados para reduzir a morbidade e a mortalidade por hipertensão, diabetes e câncer, na sua maioria, não foram implementados pelos gestores da saúde nos estados.

Diversas são as razões que se tem para explicar o aumento dos problemas crônic os. Black e Matassarin-J a cobs (1996), por exemplo, a pontam que os avanços nos campos da bacteriologia, imunologia, saúde pública e farmacologia levaram a uma rápida redução da mortalidade por doenças anteriormente fatais o que fez com que houvesse aumento da longevidade e maior risco de acidentes e doenças que podem transformar-se em condições crônicas. As autoras ainda afimam que, durante os últimos 40 anos, avanços no conhecimento sobre a função fisiológica e nas técnicas e equipamentos para avaliação e diagnóstico de alterações da função física, suporte e manutenção da vida, combate à infecção, manutenção e restabelecimento da função física, reparo e substituição da função física perdida, 
contribuíram para a umentar a sobrevida das pessoas. Esses a vanços favoreceram o surgimento de problemas crônicos de saúde.

Lessa (1999), por sua vez, aponta a falta de disponibilidade quantitativa e qualitativa e a não abrangência da assistência médica preventiva, curativa e de reabilitação a toda a população, frutos do modelo de organização do sistema de saúde, como fatores que contribuem para o aumento das doenças crônicas, considerando-os co-responsáveis pela sua deteminação e co-participantes na deteminação das complic ações e mortes evitá veis.

Q uaisquer que sejam as explic ações, o fato é que os problemas crônic os estão aí e têm gerado um impacto muito grande na vida e na saúde de muitas pessoas, de suas famílias, bem como, na sociedade e no país. É fundamental que sejam conhecidos estes problemas, quem os tem, as conseqüências que eles acarretam aos indivíduos, à sociedade e o ao país, e que sejam implementadas intervenções adequadas e efic ientes que minimizem o problema no Brasil.

Dentre as doenças crônicas não-transmissíveis, destaca-se a hipertensão arterial (HA), um problema de saúde universal que, como entidade isolada, é a mais ou encontra-se entre as mais freqüentes morbidades do adulto em todo o mundo industrializado e na maioria dos países em fase de desenvolvimento, sobretudo nos grandes centros urbanos, acometendo todas as classes socioeconômicas (LESSA, 1998a).

Definições são importantes. O VI J oint National Committee (J NC) (1997, p. 11) define hipertensão como "pressão a rterial sistólica (PAS) maior ou igual a 140mmHg, pressão arterial diastólica (PAD) maior ou igual a $90 \mathrm{mmHg}$, ou necessidade de utilização de medicação anti-hipertensiva". Segundo o VII J NC (CHOBANIAN et al., 2003), níveis de PAS entre 140 e 159 mmHg e PAD entre 90 e 99 mmHg ou ma is, são considerados valores de hipertensão.

O III Consenso Brasileiro de Hipertensão Arterial (CBHA) (1998, p. VI), considera que a hipertensão arterial é "uma entidade clínica multifa torial, conceitua da como síndrome caracterizada pela presença de níveis tensionais elevados, associados a alterações metabólicas e homona is e a fenômenos tróficos (hipertrofias cardíaca e vascular)". De acordo com as IV Diretrizes Brasileiras de Hipertensão Arterial (Diretrizes Brasileiras de Hipertensão Arterial, IV, 2002), os valores que permitem 
classificar os indivíduos adultos a cima de 18 anos com hipertensão são: PAS entre 140 e $159 \mathrm{mmHg}$ e PAD entre 90 e $99 \mathrm{mmHg}$ ou mais.

Para a Organização Mundial da Saúde (OMS), "hipertensão é definida como PAS de $140 \mathrm{mmHg}$ ou ma is e/ou uma PAD de $90 \mathrm{mmHg}$ ou mais, em sujeitos que não estão tomando medicação anti-hipertensiva“ (WORLD HEALTH ORGANIZATION (WHO), 1999, p. 62).

São definições da hipertensão arterial que, por si só, não abarcam sua magnitude. Mesmo que esta magnitude varie amplamente, dependendo das caracteństicas biológicas e demográficas das populações, do estilo de vida de cada uma delas, do ambiente físico e psicossocial e até das caracteństicas da organização dos serviços de saúde e das respectivas interações entre eles (LESSA, 1998), a HA permanece como um sério problema de saúde pública que afeta grande número de pessoas em muitas sociedades.

A OMS afirma que vem ocorrendo um crescente e rápido desenvolvimento das doenças cardiovasculares da segunda metade do século XX em diante. A elevação da pressão arterial tem um papel central na patogênese das doenças coronárias e do acidente vascular cerebral o que concorre para que as autoridades de saúde pública e os profissionais de saúde tenham como um dos maiores desafios o controle da hipertensão pelo mundo inteiro, tanto em indivíduos quanto em populações (WHO, 1999).

No mundo, cerca de $20 \%$ da população adulta é hipertensa e as freqüências em países em desenvolvimento continuam a aumentar. E o que é pior, tem-se observado crescente aumento do número de crianças e adolescentes que são consideradas hipertensas (STEVENSON, 1999).

No Brasil, é a lta a prevalência da hipertensão a rterial. Estima-se que cerca de 15 a $20 \%$ da população brasileira adulta possa ser rotulada como hipertensa (III CBHA, 1998). Lessa (1998a) declara que dados obtidos recentemente por investigadores demonstram que a prevalência da HA em nosso país é elevada, estando muitas vezes entre 20 e 30\%. Segundo as IV Diretrizes Brasileiras de Hipertensão Arterial (DBHA, 2002, p. 2), “utilizando-se o critério atual de diagnóstico de hipertensão arterial ( $\geq 140 / 90 \mathrm{mmHg}$ ), as taxas de prevalência na população urbana adulta brasileira em estudos seleciona dos variam de $22,3 \%$ a 43,9\%". 
Em Mato Grosso, local de realização deste estudo, em 2002, na campanha realizada pelo govemo do Estado de Mato Grosso para detectar casos suspeitos de hipertensão arterial, em 50,2\% da população alvo (373.264 adultos com idade a cima de 40 anos) constatou-se a presença de 62.922 pessoas $(33,5 \%)$ com pressão arterial elevada (MATO GROSSO, 2002).

Sua importância reside no fato de ser uma doença não só de alta morbidade, mas que também apresenta taxa significativa de mortalidade. A HA é o principal fator de risco para as doenças cardiovasculares que, no Brasil, são a primeira causa de morte na população adulta. Em 1998, essas doenças corresponderam a 32,6\% dos óbitos totais do país (FUNDAÇÃO NACIONAL DE SAÚDE, 2002). Bloch (1998, p. 54) a fimma que “o a umento da pressão a rterial, sistólica ou diastólica, em qualquer idade e sexo, resulta em um substancial aumento da morbimortalidade por vários transtomos cardiovasculares e renais". O Ministério da Saúde (MS) diz que aproximadamente $85 \%$ dos acidentes vasculares cerebrais e $40 \%$ das vítima s de infarto do miocárdio têm hipertensão associa da (BRASIL, 2001).

O quadro da hipertensão toma-se mais sério na medida em que se constata que grande número de pessoas não sabe que são hipertensas e que não é signific ativa a proporção dos que estão sob tratamento e têm a PA controlada. De acordo com o VII J oint National Committee (CHOBANIAN et al., 2003), embora as taxas de controle da PA tenham apresentado um pequeno aumento nos últimos anos, a porcentagem de pessoas que não sabem ser hipertensas ainda é significativa.

No Brasil, em 1988, o MS afirmava que mais da metade dos hipertensos não sabiam que eram hipertensos e, portanto, não eram atendidos pelo sistema de saúde (BRASIL, 1988).

Em 1999, a OMS afimou que "somente metade de todos os hipertensos é ciente de que tem hipertensão, somente metade dos que são cientes está realmente em tratamento, e somente metade dos que estão sob tratamento tem sua pressão sanguínea controlada" (WHO, 1999, p. 177).

Embora a HA atinja todas as classes socioeconômicas, há grupos que sofrem mais com a doença, não só por razões biológicas, mas igualmente pelas psicossociais, socioambientais, socioculturais e socioeconômicas que agem de modo aditivo e sinergístico no conpo e na vida destes grupos. São grupos que têm 
que se empenhar pela sobrevivência em comunidades pobres, que são as maiores vítimas da violência e da discriminação e que têm dificuldades de acesso aos sistemas social, econômico, educacional e de saúde de boa qualidade. Dressler e Santos (2000, p. 305), citando vários autores, colocam que "todos eles encontra ram pressão arterial média e prevalência de hipertensão mais alta entre pessoas com status ocupacional, educacional e de renda, mais baixo".

De acordo com o VIJ NC (1997), a maior prevalência de HA ocorre entre os negros, e quando comparados aos brancos, eles apresentam a doença mais cedo e níveis tensionais muito mais elevados. Isto é acompanhado de taxa de mortalidade por AVC 80\% maior, taxa de mortalidade por doença cardíaca 50\% maior, e taxa de doença renal terminal relacionada à hipertensão 320 vezes maior do que a observada na população em geral.

Da mesma foma, Lopes (1996, p. 158) confima que “os dados dos principais estudos epidemiológic os conduzidos nos Estados Unidos e no Brasil demonstram de forma consistente que os negros têm risco maior do que os brancos para a HA, partic ula mente para asformas mais graves da doença".

Segundo o III CBHA (1998, p. 27), “estudos epidemiológicos brasileiros demonstram que a prevalência de HA entre idosos, à semelhança da observada em todo mundo, é bastante elevada". Estima-se que a porcentagem de idosos hipertensos é de aproximadamente $65 \%$, e entre mulheres com mais de 75 anos a prevalência de HA pode chegara $80 \%$.

A HA não tem causa específica e conhecida, mas possui na sua história, uma série de indicadores de risco que, explicados ou não, têm forte associação com a doença. Dentre eles estão o sexo, a idade, a raça, a história familiar, a obesidade, o álcool em excesso, o sedentarismo, a sensibilidade ao sódio, a baixa ingestão de potássio, o estresse, o colesterol alto e algumas doenças, como o diabetes.

Contribuem também para o seu surgimento, fatores socioeconômicos, culturais e psicossociais, bem como a ausência de programas de promoção e proteção à saúde (Lessa, 1998a).

Devido à sua complexidade, a HA causa impactos muito grandes no âmbito pessoal, familiar e social daqueles que a tem. Segundo o MS, a hipertensão arterial e o diabetes mellitus, "com freqüência levam à invalidez parcial ou total do 
indivíduo, com graves repercussões para o paciente, sua família e a sociedade" (BRASIL, 2001, p. 5).

Reiners et al. (2002), em pesquisa sobre o significado que os clientes hipertensos dão ao fato de estarem com um problema crônico de saúde constataram que o impacto na vida daquelas pessoas era significativo. Elas referiram que depois de saberem que eram hipertensas e que teriam que se submeter às exigências do regime terapêutico, suas vidas mudaram porque passaram obrigatoriamente a ter constante vigilância com a saúde, abdicaram de coisa importantese sentiam-se com sua liberdade limitada.

Embora, na maioria das vezes, a HA seja uma doença assintomática, os sina is e sintomas que surgem em conseqüência das complicações, expressam de forma objetiva que já ocorreram mudanças importantes no funcionamento do corpo, sendo a lgumas delas irreversíveis.

Igualmente impactantes são as manifestações psicoemocionais que assumem formas e graus diversos dependendo da pessoa e do apoio dado a ela, bem como do peńodo no qual se encontra o processo de adoecer. Segundo Black e Matassarin-Jacobs (1996) os períodos nos quais ocorrem modificações das demandas psicológicas costumam ser o início da doença e seu diagnóstico, nas hospitalizações, na exacerbação da doença, no fracasso dostratamentos e perda dascapacidades de autocuidado.

As exigências do regime terapêutico como dieta diferenciada, inclusão de atividades físicas à vida diária e de ingestão regular de medicamentos, em si já se constituem em modific ações nos seus hábitos de vida e no de sua família que passa a tero seu funcionamento efetivo alterado.

As mudanças também ocorrem no trabalho. Em um estudo de 19 anos de follow-up realiza do por Kiiskinen et al. (1998, p. 1106), com o objetivo de estimar os custos da hipertensão e o impacto na expectativa de vida de hipertensos constatou-se que "homens com hipertensão severa perderam 2,6 ma is anos de trabalho do que os homens nomotensos, dos quais 1,6 anos foram devido à mortalidade prematura e 1 ano devido à incapacidade".

Economicamente, as perdas financeiras são significativas tanto para a pessoa doente como para a família. Muitos, obrigadosa reduzir sua capacidade de 
trabalho ou até mesmo afastar-se dele precocemente, a comprar medicamentos ou a té contra tar serviç os espec ia liza dos, vêem suas reservas fina nc eiras ming ua rem.

Ainda do ponto de vista econômico, para o país, a HA e suas complicações implicam em gastos com medicamentos, licenças médicas prolongadas ou freqüentes, a posentadorias precoces, hospitalizações, serviços especializados que demandam alta tecnologia, com cuidados multidisciplinares, entre outros. De acordo com o MS, "na faixa etária de 30 a 60 anos, as doenças cardiovasculares foram responsáveis por $14 \%$ da totalidade de intemações, sendo $17,2 \%$ por AVE ou IAM, resultando em gastos da ordem de 25,7\% do total"; e dados do Instituto Nacional de Seguridade Social (INSS) demonstram que 40\% das aposentadorias precoces decorrem da quelas doenças (BRASIL, 2001).

A importância da HA como problema de saúde pública reside também no seu difícil controle, fato que há muito tempo tem sido um grande desafio para os govemos e profissionais de saúde. De acordo com o VII J NC (CHOBANIAN et al., 2003), as taxas de controle da PA atuais (34\%), embora tenham aumentado, ainda estã o muito abaixo daquelas estabelecidas como meta para o ano de 2010 (50\%).

A OMS (WHO, 1999) diz que a despeito dos benefícios do tratamento da hipertensão estabelecidos em experimentos randomizados controlados, muitos estudos populacionais têm demonstrado que pacientes hipertensos, alguns anos depois de começarem a terapia anti-hipertensiva, continuam a experimentar riscos mais altos de doenças coronarianas, demame e mortalidade em geral do que pessoas nomotensas. O fato da PA permanecer elevada nesta população tem sido apontado como um dos fatores para que esses riscos existam.

As razões para que esta doença não esteja sob domínio, começam por aquelas que estão em uma esfera mais ampla, como a incipiente eficácia e resolutividade das políticas públicas e descaso de alguns govemos. "O Brasil continua praticamente estagnado no que se refere aos níveis de a tenção à saúde, em relação a estas doenças", afirma Lessa (1999, p. 296) ao fazer uma comparação dos resulta dos positivos na mortalidade por doenças cardiovascula res obtidos por países desenvolvidos e em desenvolvimento que adotam programas sistema tiza dos para as doenças c rônicas não tra nsmissíveis.

Curiosamente, quase que como uma resposta a esta observação, em 2001, o govemo federal lançou o Plano de Reorganização da Atenção à Hipertensão 
Arterial e ao Diabetes Mellitus com o propósito de "vincular os portadores desses agravos às unidades de saúde, garantindo-Ihes acompanhamento e tratamento sistemático, mediante ações de capacitação dos profissionais e de reorganização dos serviços" (BRASIL, 2001, p. 5). Entretanto, embora esta medida seja um avanço no controle dessas doenças, ainda carece de resultados positivos concretos, passíveis de serem obtidos somente ao longo de anos, que demonstrem sua eficácia não apenas na detecção dos suspeitos e no seu acompanhamento, mas também na capacidade de manter sua adesão ao regime terapêtico.

Da mesma forma, um dos motivos apontados na literatura pelos qua is a HA ainda não alcançou o controle adequado, tem sido a equipe de saúde que, em muitos casos, têm falhado em dar o suporte necessário ao cliente para que ele prossiga com o regime terapêutico. A OMS afirma que as falhas do médico em esta belec er relações e comunic ações efetiva s com o paciente gera Imente levarão à baixa adesão ao tratamento e a um controle insatisfa tório da PA - “a magnitude deste problema está refletido nas pesquisas populaciona is que demonstram que a HA não é tratada ou é inadequadamente controlada em cerca de $70-75 \%$ dos pacientes no mundo inteiro" (WHO, 1999, p. 171).

Por fim, na outra ponta está o cliente cuja responsabilidade pelo insuficiente controle da HA provém do fato de não aderir ao tratamento. De acordo com o VI JNC (1997, p. 19), “a maioria dos pacientes com hipertensão estabelecida não adota mudanças suficientes no estilo de vida, não toma medicação ou não faz uso de medicação sufic iente para atingir o controle".

Diante do exposto, pode-se concluir que a HA constitui importante problema de saúde pública que exige medidas de ataque para conter sua progressão. Daía importância que se dá à sua detecção, prevenção, tratamento e controle em todas as sociedades. Cremos que são etapas de um processo que não tem fim e que nenhuma é mais importante que a outra.

Entretanto, como enfermeira e docente, há algum tempo temos tido interesse pelo tema adesão / não-adesão ao tratamento, particula mente no que diz respeito à relação que ele tem com a equipe de saúde e o cliente.

Isto posto, passamos a discorrer sobre o assunto que nos motivou a fazer esta pesquisa. 


\subsection{ADESÃO / NÃO-ADESÃO AO REGIME TERAPÊUTCO}

O tratamento da HA, cujo objetivo é a redução da morbimortalidade cardiovascular do cliente hipertenso, constitui-se, basicamente, de duas modalidades: a farmacológica e a não-famacológica. O cliente, a depender do nível de pressão arterial, da estratificação do risco individual e da presença ou não de lesões em órgãosalvo, será submetido a uma ou a ambasas modalidades a fim de a tingir o controle da pressão arterial, mantendo-a em níveis a ceitá veis.

A primeira, como o próprio temo diz, refere-se ao tratamento feito à base de fámacos, que graças ao crescente desenvolvimento tecnológico e das pesquisas, são diversos e de boa qualidade, existindo à disposição da comunidade médica um arsenal de medicamentos de comprovada ação terapêutica. Isto contribui para que, na atualidade, o tratamento famacológico da HA seja um dos mais completos.

As medidas não-famacológicas constituídas pelas adaptações nos hábitos alimentares e no estilo de vida interrompendo ou restringindo comportamentos nocivos à saúde, como parar de fumar e introduzindo outros comportamentos que reduzem os riscos à saúde, como exercitar-se regulamente, e fazer acompanhamentos de saúde periódicos com a equipe multiprofissional, têm sido objeto de investigações. Algumas já a presentam comprovada eficácia na redução da PA, como a perda de peso e a atividade física regular.

Estudos têm evidenciado a eficiência do tratamento da HA. Conforme o VI J NC (1997, p. 23), “a redução da pressão arterial com fá ma cos diminui claramente a morbidade e a mortalidade cardiovasculares". Neste documento, os "experts" afimam que foi demonstrada proteção contra AVC, eventos coronarianos, insuficiência cardíaca, progressão da doença renal, da hipertensão na sua forma mais grave e, ainda mortalidade portodasascausas. O III CBHA (1998) declara que comprovadamente a redução do peso corporal, da ingestão do sal e do consumo de bebidas alcoólicas, bem como a prática de exercícios físicos com regularidade e a não-utilização de drogas hipertensoras, reduzem a pressão a rterial.

A prática também tem evidenciado que o tratamento, quando prescrito corretamente pelo médico, acompanhado adequadamente por profissionais de saúde (médico, enfermeiro, nutricionista, psicólogo, entre outros), e seguido pelos 
hipertensos, contribui para a redução das chances de ocorência de acidente vascular cerebral e para prevenir ou retardar a progressão da insuficiência cardíaca e renal. Em adição, o tratamento promove melhor qualidade de vida ao hipertenso, na medida em que concorre com a modificação de hábitos e comportamentos nocivos à saúde.

Entretanto, teoria e prática também têm mostrado que no cotidiano da assistência à saúde dos hipertensos, nenhum problema é tão ma is freqüente quanto a dificuldade que os clientes têm para seguir o tratamento. A despeito de seus benefícios, o tratamento da HA encontra na sua adesão, um grande e sério problema, cujas conseqüências são a falta de controle da doença e o aumento da morbimortalida de por distúrbios ca rdiovasculares.

Segundo Bittar (1995), mesmo com drogas efetivas que têm mostrado serem capazes de reduzir a morbidade e a mortalidade, a falta de adesão a o tratamento aparece como uma grande barreira para alcançara sua redução.

De acordo com Khalil e Elzubier (1997), a não-adesão a o tratamento pode levar à desnecessária prescrição de drogas ou à mudança de uma medicação para outra, sem que a PA seja controlada; pode levara a amento de intemações evitáveis e ao aumento no custo do cuidado de saúde. Da mesma foma, Caro e Speckman (1998) a firmam que hospitalizações freqüentes têm associação com a não-adesão a o tratamento.

Nos Estados Unidos, estima-se que 40 a $60 \%$ dos clientes com hipertensão deixam de seguir o tratamento prescrito (BLACK; MATASSARIN-JACOBS, 1996). Segundo Kochare Woods (1990, p. 184),

[...] a cada passo do acompanhamento, muitos pacientes desistem. Até 50\%
deixam de seguir os conselhos da primeira consulta, e dos que iniciam o
tratamento, mais de $50 \%$ o interrompem no período de um ano, e somente
dois terços dos que continuam se tratando chegam a o ponto de controle da
sua pressão sanguínea.

Smeltzer e Bare (1994) confimam estes dados dizendo que aproximadamente $50 \%$ dos hipertensos, nos Estados Unidos, interrompem seu tratamento 
medicamentoso no período de um ano depois que o começaram e somente $20 \%$ deles mantém o controle satisfa tório da pressão arterial.

No Brasil, em 1988, o MS divulgava que "ma is da meta de daqueles que sabem apresentar hipertensão arterial abandonam o tratamento por diversos motivos" (Brasil, 1988, p. 11-12). Em 1998, Lessa (1998b, p. 227) declarou que são raros os estudos sobre adesão a o tratamento, entretanto, confima que

[...] há muito tempo os inquéritos epidemiológicos sobre prevalência da hipertensão têm demonstrado que pelo menos $50 \%$ dos hipertensos conhecidos não faz nenhum tipo de tratamento e, dentre os poucos que fazem, uma parcela reduzida tem a pressão arterial controlada.

A não-adesão ao tratamento é mais freqüentemente encontrada em certos grupos: "adesão à terapia é mais baixa em pacientes negros do que em pacientes brancos, particulamente em jovens" (CLARK, 1991, p. 668). "As freqüências de controle são mais baixas entre as minorias e grupos socialmente em desvantagem" (SHEA, 1994, p. 1725).

De acordo com Francis (1991), não-adesão e abandono do tratamento são ma is freqüentes em populações que moram em subúrbios nas qua is ta mbém estão presentes o analfabetismo, a pobreza, altos índices de dependência química, condições ruins de moradia e dificuldade de acesso aos serviços de saúde. Esses fatores cooperam para que essas pessoas sejam menos capazes de seguir o regime prescrito.

A literatura apresenta uma variedade de termos para designar o nãoseguimento do tratamento por parte das pessoas com problemas crônicos de saúde, por exemplo, não-adesão ao tratamento, falta de colaboração com o regime terapêutico, não-comprometimento com o tratamento, falta de aderência ao tratamento, infidelidade ao tratamento, não-obediência ao tratamento, abandono de tratamento, controle ineficaz do regime terapêutico, entre outros; e noncompliance, em inglês (KOCHAR; WOODS, 1990; SMELTZER; BARE, 1994; BLACK; MATASSARIN-J ACOBS, 1996; CARPENITO, 1997; LESSA, 1998b).

$\mathrm{Na}$ verdade são temos usados em oposição à adesão, seguimento, fidelidade, entre outros, cuja definição pode ser "situação na qual o 
comportamento do paciente, avaliado pelo comparecimento às consultas marcadas, pelas tomadas das prescrições ou pelas mudanças de estilo de vida, corresponde a o conselho do médico ou de saúde" (OIGMAN, 2001, p. 38). Também pode ser: "uma perspectiva de abordagem que leva em conta as açõese omissões para certos comportamentos, de interesse médico, de um determinado indivíduo na condição de paciente clínico" (SANTOS, 2000, p. 14).

Mesmo havendo discordância de alguns autores na conotação que o termo possa ter em relação ao papel do cliente no tratamento (FOSTER; KOUSCH, 1988; PIERIN, 2001), pensamos que, em última instância, em todos os casos, as definições se assemelham.

Portanto, por preferência, neste trabalho, será adotado o temo adesão ao regime terapêutico definido como: atitudes e comportamentos do cliente que condizem com o conjunto de medidas terapêuticas prescritas para o controle da doença [medidasfarmacológicase não farmacológicas].

Estamos de a cordo com Santos (2000, p. 14) que a firma:

\footnotetext{
Caracteriza da como processo, a questão não é tão simples como aparenta, pois não se esgota nos gestos e nas atitudes imediatamente observáveis, sendo, pelo contrário, parte de um todo comportamental mais complexo que chega a incluir outros atores sociais. Além disso, apresenta variações significativas de uma cultura para outra e, mesmo dentro de uma mesma cultura, de um segmento cultural para outro.
}

Também em concordância com Porta apud Car (1998, p. 142) que diz que a adesão "é fruto da compreensão da própria situação de saúde e qualidade da integração médico-paciente que mensura a adaptabilidade das intervenções a fatores subjetivos, históric ose a mb ientais".

Do mesmo modo, utilizaremos o termo não-adesão ao regime terapêutico definindo-o como atitudes e comportamentos do cliente que não condizem com o conjunto de medidas terapêuticas prescritas para o controle da doença [medidas fama cológicase não farma cológicas].

Na maioria das vezes, a não-adesão a o regime terapêutico é investigada em relação à ingestão das medicações sendo usados na sua avaliação os métodos de 
contagem dos comprimidos, os exames laboratoriais de urina, a monitorização eletrônica de medicamentose a detecção dos níveis sanguíneos do medicamento ou metabólitos.

Já, no cotidiano das práticas em saúde, a não-adesão a o regime terapêutico, é comumente deteminada por meio da avaliação subjetiva dos profissionais de saúde que consideram que o cliente não está aderindo quando ele lhe fomece informações sobre algumas atitudes e comportamentos, como a falha ou omissão das medicações, a não alteração do modo de vida em função do tratamento, a ausência de monitorização da pressão arterial, ou o comparecimento irregular às consultas.

De acordo com Pierin (2001, p. 25), quando se diz que um cliente não está aderindo ao regime terapêutico é preciso ter cuidado para não rotulá-lo sem uma prévia avaliação, porque existem diferentes graus de adesão. Segundo a a utora,

\footnotetext{
$\mathrm{Na}$ tentativa de avaliar os diferentes graus de adesão, verifica-se que no nível mais elevado estão os aderentes propriamente ditos, aqueles que seguem totalmente o tratamento e, no lado oposto, os desistentes, aqueles que abandonam o tratamento. No grupo dos não-aderentes estão os persistentes que até comparecem às consultas, porém não seguem o trata mento.
}

Esta questão da avaliação é especificamente importante para o enfermeiro que, ao planejar a atenção de enfermagem ao cliente hipertenso, deve, primeiramente, fazer a avaliação de sua saúde, deteminar a existência do diagnóstico de enfemagem Controle Ineficaz do Regime Terapêutico [temo utilizado pela enfermagem para designar a não-adesão ao regime terapêutico], identific ando as suas causas. Sem esta prévia avaliação, o enfermeiro certamente desenvolverá ações que não condizem com o grau de adesão do cliente.

Diversos são os fatores apontados como contribuintes da não-adesão ao regime terapêutico. Segundo Kochar e Woods (1990) as variáveis que afetam a a desão do cliente a o regime terapêutico podem serfatores que estão relacionados a ele, como os sociodemográficos: a idade, o sexo, o estado civil; como suas prioridades, percepções e motivações; seu nível de conhecimento a respeito da 
doença e efeitos colaterais do tratamento. Também podem ser os fatores ambientais: acesso a o tratamento médico, relação paciente-equipe, o custo e a preparação do medicamento e os esquemas tera pêuticos.

Da mesma forma, Smeltzer e Bare (1994) relacionam os fatores que influenciam na não-adesão a o regime terapêutico como a idade, o sexo, a raça, o status socioeconômico, a educação, a gravidade da doença, o a lívio dos sintomas, a complexidade do regime terapêutico, os efeitos colaterais desagradáveis, a inteligência, as atitudes em relação aos profissionais de saúde, a aceitação ou negação da doença, as crenças religiosas ou cultura is e os custos envolvidos na execução do regime.

De acordo com Campenito (1997), tal problema pode estar relacionado ao tratamento como, por exemplo, sua complexidade, o custo financeiro do regime, a complexidade do sistema de atendimento de saúde e os efeitos colaterais da tera pia. Seus deteminantes também podem ser fatores relacionados às pessoas e ao ambiente, como conflitos de decisão, conhecimento insuficiente, conflitos familiares, desconfiança do regime, desconfiança do pessoal de atendimento de saúde, conflitos de crenças de saúde, questionamento sobre a seriedade do problema, a suscetibilidade e os benefícios do regime, apoio social insuficiente, confiabilidade insuficiente, experiências anteriores malsucedidas. Podem ser fatores relacionados a barreiras para a compreensão como défic its cognitivos e auditivos, ansiedade, fadiga, falta de motivação, problemas de memória e fatores maturacionais como o medo de ser diferente que as crianças e os idosos podem sentir.

Lessa (1998b), por sua vez, aponta como razões para que as pessoas tenham dificuldades em seguir o regime terapêtico, a atitude pessoal, os problemas relacionados ao serviço de saúde, ao médico ou à equipe de saúde; as questões socia is e econômicas; as reações adversas ao tratamento; os estágios da própria doença, complicaçõesou presença de co-morbidades.

Pierin (2001) classifica os fatores que interferem na adesão ao tratamento do hipertenso naqueles relativos ao paciente: sexo, idade, etnia, estado civil, escolaridade e nível socioeconômico; a queles relativos à doença: cronicidade, ausência de sintomas e conseqüências tardias; os relativos a crenças, hábitos de vida e culturais: percepção da seriedade do problema, desconhecimento, 
experiência com a doença, contexto familiar, conceito saúde-doença e autoestima; os rela tivos a o tra ta mento: custo, efeitos ind esejá veis, esquemas complexos, qualidade de vida; os referentes à instituição: política de saúde, acesso a o senviço de saúde, distância, tempo de espera e tempo de atendimento; e, por fim, aqueles referentes ao relacionamento com a equipe de saúde: envolvimento e relacionamento inadequado.

Diante de tais fatores podemos perceber a variedade e a complexidade de elementos que contribuem para que a pessoa com um problema crônico de saúde, como a hipertensão, tenha dificuldades com a adesão a o regime terapêutico. Em suma, estão envolvidas as características sociodemográficas dos hipertensos e sua situação de saúde, os fatores políticos, socioeconômic os, culturais e ambientais que fazem parte de seu contexto de vida e saúde, a quantidade e a qualidade dos serviços de saúde ofertados a eles e o tratamento complexo a que a lguns estão submetidos.

Como foi visto, na literatura referente ao tema adesão / não-adesão ao tratamento muitos autores fazem referência à interação entre o profissional de saúde e o cliente como um fator que contribui para que o regime terapêutico seja preterido pelo último.

Como este é o aspecto do problema que nos interessa investigar, discorreremos sobre ele no próximo tópico.

\subsection{INTERAÇÃO PRORSSIONALDE SAÚDE / CUENTE}

Há algum tempo, estudos sobre a não-adesão assumem a questão da interação entre o profissional de saúde e o cliente como um fator que contribui para que ela ocorra.

Embora na maioria dos trabalhos os autores se preocupem com a interação entre o médico e o cliente, nesta pesquisa nosso interesse foi com a interação entre os profissiona is de saúde que interagem com o cliente hipertenso.

Neste sentido, quando nos referimos ao profissional de saúde, incluímos o enfermeiro e os demais integrantes da equipe de enfermagem [pessoal de 
enfermagem] porque, como enfermeira, nos interessa também compreender a interação desses profissionais com o cliente e a natureza dessa interação.

Existe um número considerável de autores afimando e demonstrando que a interação entre o cliente e o profissional de saúde é um fator de impedimento para a eficiente adesão do primeiro ao regime terapêutico. Para Pierin (2001, p. 27), “a relação médico-paciente é um fator altamente interveniente na adesão do hipertenso ao tratamento". Clark (1991) coloca as comunic ações entre o médico e o paciente como uma das principais barreiras para a adesão ao tratamento, a o lado dos custose efeitos cola tera is das medic ações.

Stockwell et al. (1994, p. 1772-3) declaram que a razão mais comum para a ocorência de falha no tratamento é o relacionamento entre o paciente e o médico, juntamente com o custo e os efeitos colaterais da medicação. Os autores acrescentam: "para a maionia das pessoas com pressão alta, visitas periódicas ao consultório médico simplesmente não produzem o resultado esperado". Este fato foi comprovado pelos autores a o realiza rem um estud o com trabalha dores hipertensos no qual compararam, entre aqueles que estavam em tratamento, os que fizeram mais visitas ao consultório médico - sete por ano - com aqueles que foram com menor freqüência ao médico. Os pesquisadores concluíram que $75 \%$ dos trabalhadores que visitavam regulamente o médico não alcançaram maior controle da pressão sanguínea.

Guerra e Araújo (1999, p. 44) em uma pesquisa sobre a adesão a o tratamento da hipertensão arterial relatam que a "significativa incidência de dadosapontados pelos respondentes (10,15\%) revela a inadequação do relacionamento cliente / profissional, caracterizado por consultas superficia is e impessoais, nas qua is faltam orienta ções, estímulo e motivação a o cliente".

Em outra pesquisa sobre o déficit de conhecimento em portadores de hipertensão arterial, Araújo e Batista (2000, p. 153) afirmam que a “barreira que muitas vezes se cria entre o profissional e o cliente, dificulta a terapêutica e pode levá -lo a interromper o tratamento".

A foma como o profissional de saúde tem abordado o cliente e suas necessidades tem sido apontada como um elemento limitante na relação entre os dois. Romano (1999, p. 57), preocupada com a interferência dos fatores psicológicos na adesão ao regime terapêutico, afima que "a ação médica no 
tratamento da hipertensão arterial focalizada primariamente no controle da pressão sanguínea, sem considerar em profundidade outros fatores que contribuem para a doença aterosc lerótic a, tem seus efeitos muito limita dos".

Kjellgren, Ahlner e Säljö (1995) dizem que a questão da baixa adesão dos pacientes pode ser a não percepção do problema pelos médicos. Devido ao fato de a adesão envolver uma complexa variedade de comportamentos, muitos deles os ignoram completamente e não usam as ferramentas que existem à sua disposição para lidarcom o problema.

É certo que a interação entre o profissional de saúde e o cliente se dá, na maioria das vezes, em nível desigual pelo simples fato de o primeiro se considerar "detentor do conhecimento" e o segundo, não. Em um artigo sobre experiências e visões dos pacientes acerca de várias doenças crônicas, o depoimento de um cliente hipertenso deixa esse aspecto muito claro:

\footnotetext{
É realmente difícil acreditar que a pressão alta é uma doença porque não nos sentimos mal. É um peso ter que constantemente tomar medicamentos que, além do mais, nos deixam cansados. Mas nós sempre não nos atrevemos a falar sobre estas coisas porque vocês, os médicos, são tão categóricos. O que vocês nos dizem não necessariamente se aplica a todos os pacientes" (LACROIX; J ACQ UEMENT; ASSAL, 1995a, p. 302).
}

De outro modo, não há como negar que existe por parte dos clientes um contraponto àquilo que os profissionais deteminam a eles. Como refere Sawaia apud Cade (1998, p. 58): “os leigos pensam, imaginam ou têm conceitos, valores e costumes sobre as práticas de saúde que confrontam com os pensamentos dos profissiona is".

Da mesma forma, Strauss apud Kochar e Woods (1990, p. 197) afima que “nem sempre os pacientes ac eitam automatic a mente os esquemas de tratamento propostos julgando-os quanto à eficiência, à legitimidade, ou ambos e, também, segundo padrões sociais, e não médicos. Deste modo, eles serão aceitos e seguidos somente em determinadascondições".

Oigman (2001) descreve que médic ose pacientes freqüentemente discordam quanto à responsabilidade pelo insucesso do tratamento, os primeiros alegando 
que isto se deu porque os pacientes não aderiram ao regime terapêutico e os últimos creditam o mau controle pressóric o a os medic amentos.

Em uma pesquisa sobre o signific a do de se ter um problema crônico de saúde, suas dificuldades e implicações, Reiners et al (2002) obtiveram como um dos resultados a subcategoria Resistindo às Ordens Médicas configurando uma problemática na interação do cliente com o profissional de saúde que implicava em resistência porparte do primeiro em controlaro regime terapêutico.

Da mesma forma, em recente estudo, Wilson et al. (2002, p. 26-9) investigaram a extensão na qual as crenças de negros americanos sobre hipertensão divergem dos recentes conhecimentos médicos, sob o pressuposto de que a discordância entre eles é uma barreira potencial para o controle da doença. Os resultados demonstraram que as crenças predominantes sobre hipertensão divergem acentuadamente dos conhecimentos médic os atuais, em vários aspectos, como a definição de pressão alta, suas causas, conseqüências e tratamento. Os autores alertam que "a falta de apreciação destas crenças de saúde pelos profissionais de saúde pode contribuir para a não-adesão e persistentes baixas freqüências de controle da hipertensão".

Embora, em última instância, a adesão ao regime terapêutico dependa do cliente hipertenso e/ou de sua família; acreditamos que o govemo, os serviços de saúde e os profissionais de saúde também têm responsabilidade de compartilhar com ele(s) essa responsabilidade e garantir o suporte necessário para que estas pessoas participem efetivamente do regime terapêutico. No conjunto das práticas em saúde a enfermeira, o médico e o pessoal de enfermagem são os profissionais que usualmente prestam assistência aos hipertensos, recebendo-os, muitas vezes, em situações críticas de complicações, resultado da não-adesão ao regime terapêutico.

Observamos na prática de ensino e assistência que a interação entre estes profissionais e o cliente hipertenso nem sempre se dá de maneira sustentadora. Interagem com ele de forma inadequada, como, por exemplo, fomecendo somente breves informações, usando vocabulário de difícil compreensão, ou responsabilizando-o pelo insucesso do tratamento.

Entretanto, embora a interação entre o cliente e o profissional de saúde seja apontada na literatura como um determinante da não-adesão ao tratamento, 
para nós, não está clara a sua dimensão como causa e nem em que sentido ela concorre para dificultar o controle do regime terapêutico.

Estas são considera ções sobre as qua is temos refletido há a lgum tempo e que têm nos estimulado a fazer questionamentos sobre a contribuição da interação entre o profissional de saúde e o cliente para a não-adesão a o regime terapêutico. Como tem ocomido a interação entre o cliente hipertenso e o profissional de saúde e em que medida ela tem cooperado para a não-adesão ao tratamento? Será que existem aspectos dessa interação que têm afetado o comportamento dos clientes em relação ao regime terapêutico? Que aspectos dessa interação podem estar levando o cliente à não-adesão a o regime tera pêutico?

Nossos pressupostos são:

- O profissional de saúde age na interação de acordo com suas perspectivas, concepções, significa ções sobre o cliente, a relação que tem com ele, sobre a doença (HA) e o tratamento, bem como sobre a adesão e a não-adesão a regime terapêutico.

- O cliente também age na interação e fora dela, conforme os significados, as percepções, concepções e perspectivas que tem sobre a hipertensão, o tratamento, o profissional de saúde e a sua relação com ele, assim como sobre a adesão e a não-adesão a o regime tera pêutico.

- A não-adesão do cliente ao regime terapêutico ocorre devido à maneira como o profissional de saúde age e interage com ele.

Kochar e Woods (1990) dizem que seja qual for o papel do médico ou da enfermeira, deteminados aspectos do relacionamento entre esses profissiona is e o paciente que favoreçam [ou não] o comprometimento com o tratamento, somente poderão ser identificados através de pesquisas e publicação dos resultados.

Embora existam inúmeros estudos desenvolvidos sobre adesão / não-adesão ao tratamento e, vários deles, apontem para a interação entre o profissional de saúde e o cliente como um fator contribuinte para que esse fenômeno ocorra, no Brasil, poucas investigações têm sido desenvolvidas sobre esta temática.

Assim, tendo em vista tais considerações, bem como os nossos questionamentos, surgiu a necessidade concreta de desenvolver este estudo cujos 
resultados, acreditamos, poderão ajudar na compreensão da interação entre o profissional de saúde e o cliente contribuindo para desvelar os aspectos dessa interação que poderiam estar afetando o comportamento dos clientes em relação a o tratamento anti-hipertensivo.

Consideramos que tais resultados poderão desencadear reflexões por parte dos profissionais de saúde no que se refere à interação que têm tido com os usuários portadores de problemas crônic os de saúde e às suas ações, pensando em que medida elas têm contribuído para ajudar os clientes na adesão / não-adesão ao regime terapêutico.

Além disso, acreditamos que, pela melhora do conhecimento sobre aspectos da sua prática, os enfermeiros e os outros membros da equipe de enfermagem poderão beneficiar-se com os resulta dos deste estudo.

Porfim, ao a profundar os estudos sobre esta temática, pretendemos, no futuro, aplicá-los na implantação de um serviço de apoio a os clientes hipertensos que têm dificuldades em aderir a regime terapêutico, contribuindo para o controle da HA, a fim de minimizar o processo mórbido, prevenir complicações e reduzir a mortalidade precoce provocada pela $\mathrm{HA}$ e, conseqüentemente trazer melhor qualidade de vida e saúde àquelas pessoas.

Os objetivos desta pesquisa serão apresentadosna próxima parte. 


\section{PARIE 2 - OBJ EIIVOS DA PESQUISA}

- Compreender a perspectiva do profissional de saúde e do usuário hipertenso sobre a interação que ocorre entre eles, no contexto da atenção em unidades públic as de saúde.

- Analisar de que forma a interação entre o profissional de saúde e o usuário hipertenso contribui para a não-adesão ao regime terapêutico. 


\section{PARIE 3 - METODOLOGIA DA PESQUISA}

A seleção de um referencial teórico que levasse à compreensão da relação entre o profissional de saúde e o usuário, não foi tarefa fácil, pois existem diversas perspectivas teóricas capazes de fomecer explicações para esse fenômeno. Optamos pela perspectiva do Interacionismo Simbólico devido à proximidade com o tema de estudo pretendido e também pela foma como entendemos a realidade e tudo mais que faz parte dela.

O Interacionismo Simbólico tem como foco a interação social e considera que as ações das pessoas são frutos dessa interação. Devido ao interesse que tínhamos em compreender o que acontece na entre duas pessoas que constantemente estão em interação - o profissional de saúde e o usuário que ele assiste. Ainda, por nos preocupamos em saber em que medida essa interação influencia a não-adesão do usuário ao regime terapêutico; pareceu-nos ser o Interacionismo Simbólico a perspectiva teórica apropriada para ajudar na compreensão do fenômeno objeto desse estudo.

A escolha do referencial metodológico veio como conseqüência da opção teórica - a Teoria Fundamentada nos Dados, em inglês, Grounded Theory - um método de análise de dados qualitativos desenvolvido a partir das concepções do Interacionismo Simbólico sobre o comportamento humano.

\subsection{INIERACIONISMO SIMBÓUCO}

O Interacionismo Simbólico é uma perspectiva teórica derivada da sociologia cujo foco é o comportamento humano. "É a mais ampla perspectiva sobre o papel da comunicação na sociedade", na visão de Littlejohn (1982, p. 65).

George Herbert Mead, seu principal fundador, influenciado pelo pensamento pragmático, pelas idéias de Darwin e pelo behaviorismo, buscava compreender a conduta humana em temos sociais. Considerava que a vida em grupo "era uma condição essencial para a emergência da consciência, da mente, do mundo dos objetos, dos seres humanos como organismos que possuem um eu, e da conduta 
humana na forma de atos construídos" (BLUMMER, 1969, p. 61). Muitos estudiosos seguiram desenvolvendo as idéias de Mead sobre o Interacionismo Simbólico sendo Herbert Blummer o ma is conhecido deles.

O principal foco do Interacionismo Simbólico é a interação social entendida como ações recíprocas e dinâmicas entre pessoas que permitem interpretações e tomadas de decisões para continuar agindo. A sociedade é constituída por pessoas interagindo umas com as outrase as ações de uns ocorrem em resposta às de outros, afima Blummer (1969). "Indivíduos interagem; sociedades são constituídas pela interação entre os indivíduos. Pessoas estão constantemente mudando nesta interação, e a sociedade surge e muda através da interação social" (CHARON, 1998, p. 27).

As pessoas são a tores - a tores socia is - que estreita mente se inter-relacionam com a sociedade e desta interação decorre sempre uma ação, seja ela manifesta ou latente, mediata ou imediata, transitória ou permanente.

O ato social constitui-se na ação do indivíduo dentro de uma situação determinada por condições objetivas, pelas atitudes e valores por ele adquindos durante experiências de vida e pelas definições que este indivíduo pode conferir tanto social como psicologicamente à situação.

Os atores sociais interpretam as situações utilizando objetos, símbolos, linguagem e perspectivas para definir, deteminar o que está acontecendo na situação e, a partir daí, agir.

A perspectiva interacionista tem como uma de suas premissasa idéia de que todo ator social age em relação às coisas a partir do significado que elas têm para ele. Constantemente estamos sendo expostos a estímulos que, para o Interacionismo Simbólico, são chamados objetos.

Um objeto é qualquer coisa que pode ser indicada, qualquer coisa que é apontada ou referida - uma nuvem, um livro, uma assembléia, um banqueiro, uma doutrina religiosa, um fantasma, e assim por diante. (...) A natureza de um objeto - de todo e qualquer objeto - consiste no significado que ele tem para a pessoa. Este significado se coloca na forma como a pessoa vê o objeto, na maneira como ela é preparada para agirem relação a ele e se referir a ele. Um objeto pode ter um significado diferente para diferentes pessoas [...] (BLUMMER, 1969, p. 10 -11). 
Os objetos existem como na realidade são na sua foma natural, mas somente selecionamos aqueles que nos são relevantes porque da interação com os outros passam a fazer sentido para nós. Assim, da variedade de objetos que estão a o nosso redor, só os objetos que têm um significado é que importam e, por isso, são chamados objetos sociais. "Um objeto social é qualquer objeto em uma situação que um ator usa naquela situação. Este uso existe socialmente. Pode ser entendido e aplicado a uma variedade de situações" (CHARON, 1998, p. 46). Aprendemos uns com os outros o que os objetos são, para que servem, o que fazem. Na verdade, “os objetos só se tomam objetos por causa da percepção e experiência deles por uma pessoa" (UTTLEJOHN, 1982, p. 68). "O significado dos objetos para a pessoa emerge fundamentalmente da foma como são definidos para ela pelos outros com os quais ela interage" (BLUMMER, 1969, p. 11). Nós os definimos de acordo com o significado que, naquela situa ção, eles têm para nós e este significado pode mudarna medida em que a situação muda.

Objetos socia is que a dquirem um sentido comum por representarem a lguma coisa para as pessoas, são símbolos - um tipo especial de objeto social. São compartilha dos por pessoas e usados para comunicar algo entre elas ou para elas mesmas. As pessoas criam os símbolos a partir de um significa do comum para elas que entendem porque sabem o que representam. O símbolo representa sempre algo mais do que a simples presença do objeto; representa algo a ser usado intencionalmente, para comunicar. O ator tem que ter o objetivo de usar o objeto, diz Charon (1998) porque se não houver a intenção, não podemos considerá-lo como simbólico.

A interação social é simbólica quando envolve uma interpretação do ato, um processo reflexivo. Por isso, os signific ados têm tanta importância. Sem eles as ações são só responsivas, sem sentido. Assim, os gestos das pessoas, da mesma forma, quando significativos, são parte da interação social e contribuem para o seu entendimento. Podem ser pedidos, ordens, comandose declarações que informam à pessoa a intenção ou o plano de uma ação que irá acontecer (BLUMMER, 1969). Quando uma pessoa age em direção a outra, ela utiliza gestos indicando não só o que ela planeja fazer como, também, o que ela espera que o outro faça. A outra pessoa interpreta os símbolos contidos nos gestos, atribui-lhes um significado e planeja a sua própria resposta de acordo com o significa do que os gestos têm para 
ela. Assim, os gestos têm significados para ambas (BLUMMER, 1969, LITLEJOHN, 1982). Isto mostra "a natureza cooperativa, adaptativa e receptiva do comportamento consciente que recorre ao uso de símbolos" (LTTEE OHN, 1982, p. $69)$.

Um tipo especial de símbolo é a linguagem pela sua caractenística de comunicar e representar. Constitui-se em um sistema social e culturalmente construído para transmitir os signific a dos das coisas.

É um sistema simbólico, definido na interação, e usado para descrever a outros e para nós mesmos o que observamos, pensamos, e imaginamos. A linguagem descreve todos os objetos sociais, tudo o que as pessoas apontam uns aos outros na interação. É usada para referir ou representar uma parte da realidade. (CHARON, 1998: 52).

O mecanismo da linguagem é o elemento que explica como a interação se dá e compõe-se de sinais, signos e símbolos. É através da linguagem que os gestos se transfomam em símbolos significativos, passíveis de serem interpretados e interionizados pelo ator social. Ao interiorizá-los, a pessoa pode se colocar mentalmente no lugar do outro e despertar em si mesma a atitude que sua reação provoca no outro. Sem o uso da linguagem a pessoa não consegue incorporar as perspectivas e ações dos outros e, em conseqüência, não se socializa e nem se toma apto a assimilar papéis.

Da mesma forma, para definir a situação usamos perspectivas: um grupo de símbolos que emprestamos para nos ajudar a definir a realidade. “Não é uma caracteństica intema, mas algo que pertence, surge, é compartilhada e muda na interação social" (CHARON, 1998, p. 37). São pontos de vista sobre a realidade os qua is surgem da interação com grupos. Estes grupos, denominados grupos de referência, são aqueles que pertencem à sociedade e dos qua is fazemos parte ou não como, por exemplo, a família, a comunidade, os trabalhadores, os ambientalistas, os políticos, entre outros. Portanto, ao interagimos com os outros usamos as perspectivas dos grupos de referência para construir as nossas. A perspectiva não é estática, pelo contrário, ela sofre mudanças dura nte a interação. Sua função é servir de guia para a interpretação das ações dos outros e posteriomente para guiara definição da situação. 
$\mathrm{Na}$ verdade, não interagimos somente com os outros, mas, também, conosco mesmos. Como afima Charon, (1998, p. 27), “a ação humana é causada não somente pela interação social mas, também, pela interação do indivíduo consigo mesmo". Utilizamos mecanismos intemos para entender as ações dos outros. Nos vemos como objeto na situação e conversamos conosco mesmos, na maioria das vezes, pensando.

Interagimos com nosso self - um objeto social que usamos como uma das referências para o nosso agir.

O self não é visto como residindo no interior do indivíduo, como um ego ou um conjunto organizado de necessidades, motivações e nomas ou valores intemos. O self é a definição que as pessoas constroem (através da interação com os outros) sobre quem são. Ao construir ou definir o self, as pessoas tentam ver-se como os outros as vêem, interpretando os gestos e as ações que thes são dirigidas e colocando-se no papel da outra pessoa. (BOGDAN; BIKLEN, 1994, p. 57).

O self é um processo no qual coexistem duasfases a nalític as: o eu e o mim. O eu representa o início do processo que se desenvolve no interior da pessoa quando ela vai agir; é instintivo, impulsivo, espontâneo, não planejado e desorganizado; explica os impulsos criativos e imprevisíveis da pessoa (LTTEJOHN, 1982). Seria a parte do self não socialmente controlada que, de alguma forma, explica porque em certas situações a gimos de maneira espontânea, criativa ou impulsiva.

O mim é a parte do processo posterior à interação da pessoa com outros e na qual ele incorporou os sentidos dos outros para aquela situação. É a resposta da pessoa a partir da percepção que tem dos outros e que os outros têm dele e de acordo com as regras socialmente desenvolvidas pela socieda de.

As pessoas "não tomam consciência do seu meio diretamente, em vez disso, definem a situação enquanto agem" (CHARON, 1998, p. 27). Constantemente interagem consigo mesmas e com outros, através da comunicação e da representação, utilizando objetos socia is, símbolos e perspectivas para interpretar as situaçõese, a partir daí, definir uma linha de ação. 
Ao entrar na situação para defini-la, o ator social encontra-se em uma condição ainda indeteminada. A compreensão das motivações do ator, bem como de seus objetivos, é indispensável. A partir do momento que ele os pré-define, a situação já não é mais considerada como uma configuração invariável de estímulos, mas sim como um campo rico em objetos significativos em constante interação.

A pessoa não só determina seus objetivos, mas aplica suas próprias perspectivas para definir a situação, ou seja, vê a situação de um jeito que só ela consegue ver. Percebe-se também como membro de um ou mais grupos, ocupando espaço na sociedade. Do mesmo modo, o ator identifica seu papel no grupo e assimila o(s) papel(is) do(s) outro(s) a fim de que haja mútua assunção de papéis; porque é preciso que se perceba as intenções do outro para que haja efetiva interação. Quando a pessoa usa um grupo como referência para seu ponto de vista, este é o grupo de referência que o auxiliará na definição da situação.

Ao mesmo tempo, aplica experiências passadas considerando-as na situação presente e não deixa de considerar o futuro quando imagina as possíveis definições da situação. Ao pontuar, ponderar, considerar e selecionar os dados significativos da situação que se apresenta, a pessoa está interpretando e avaliando a situação como se estivesse inserida na mesma. Na verdade, ela vê a si mesma na situa ção.

Na medida em que a situação já está definida para a pessoa, ela detemina uma linha de ação com base na interpretação obtida e assim, age. Ao agir está realizando um ato que se toma social na medida em que leva em consideração o comportamento dosoutrose por ele se orienta.

Do mesmo modo, as outras pessoas que estão interagindo com ela nesta mesma situação, interpretam-na de acordo com suas próprias perspectivas, definindo-a e determinando suas linhas de ação, realizando seus próprios atos socia is.

A pessoa interpreta suas próprias ações à luz das ações das outras pessoas e detemina o que isso significa para ela. Assim, ela revê a situação a partir de uma outra perspectiva, define-a de outra maneira e determina uma nova linha de ação.

Esta visão pode ser aplicada igualmente para entender as ações coletivas. A ação é coletiva quando surge e se configura a partir das ações dos elementos de 
um grupo. Eles compartilham um mesmo mundo de objetos, mas cada um participa com seu próprio esquema de interpretação. Cada pessoa, depois que define a situação, é capaz de guiar seu próprio comportamento à luz do conjunto de significados estabelecidos pelo grupo.

\subsection{TEORIA FUNDAMENTADA NOS DADOS}

A Teoria Fundamentada nos Dados foi desenvolvida por Bamey Glaser e Anselm Strauss nos anos sessenta durante um estudo realiza do com profissiona is de saúde que lidavam com pacientes termina is. Strauss (1987, p. 5), afirma que a Teoria Fundamentada nos Dados não é um método ou uma técnica.

\footnotetext{
Em vez disso, ela é um estilo de fazer análise qualita tiva que inclui um número de caracteństicas distintas, tais como a amostragem teórica e certas instruções metodológicas, como a constante comparação e o uso de um modelo de codificação, para assegurar desenvolvimento conceitual e densidade.
}

Ainda, segundo o autor, a Teoria Fundamentada nos Dados baseia-se na premissa de que qualquer nível de explicação é indispensável para o aprofundamento do fenômeno social e argumenta que ela [a explicação] deve ser desenvolvida em íntima relação com os dados [fundamentada nos dados], sendo o próprio pesquisador um instrumento para o desenvolvimento do trabalho teórico (STRAUSS, 1987).

Segundo Strauss (1987), a abordagem qualitativa de análise de dados Teoria Fundamentada nos Dados - é denominada assim porque enfatiza a construção de uma teoria sobre o fenômeno estudado; construção esta fundamentada nos dados que vão sendo colhidos.

De acordo com Minayo (1993, p. 91-2), teoria é “um conjunto interrelacionado de princípios e definições que servem para dar organização lógica a aspectos selecionados da realidade empírica". Segundo ela, "a essência de uma 
teoria consiste na sua potencialidade de explicar uma gama ampla de fenômenos através de um esquema conceitual a o mesmo tempo abrangente e sintético".

Continuando, a autora diz que o aprofundamento da teoria pemite desvendar dimensões não pensadas a respeito da realidade que ainda não é evidente e que se revela a partir de interrogações elaboradas no processo de construção teórica.

Conforme Strauss (1987), a Teoria Fundamentada nos Dados baseia-se na premissa de que a teoria, qualquer que seja seu nível de generalização, é indispensável para o aprofundamento do conhecimento do fenômeno social. Entretanto, o autor argumenta que a teoria deve ser desenvolvida em íntima relação com os dados e com os pesquisadores cientes de que são instrumentos desta construção teórica, seja produzindo os dados ou fundamentando seu trabalho teórico com dados coletados por outros.

Para tal, o pesquisador precisa desenvolver um processo que envolve ações de coletar dados, tomar notas e analisar. Esse processo de coleta e análise dos dados é determinado por um procedimento chamado amostragem teónica que consiste em tomadas de decisão por parte do pesquisador no sentido de saber quais dados coletar em seguida e onde encontrá-los. Significa escolher locais, pessoas, documentos ou outra fonte de dados significativos que, muito provavelmente, darão cond ições a o pesquisador de checar suas hipóteses.

Com base no exposto, a presentamos a seguir os procedimentos por meio dos qua is os dados desta pesquisa foram obtidos, os loca is selecionados para a coleta, os participantes do estudo, bem como o tratamento e a a nálise dos dados.

\subsubsection{OBIENÇÃO DOS DADOS}

\subsubsection{Local de obtenção dos dados}

Com a finalidade de coletar os dados necessários ao alcance dos objetivos propostos, e como nossa preocupação residia nas interações entre o profissional de saúde e o usuário fora do contexto hospitalar, optamos por desenvolver este estudo 
em unidades públicas de saúde que prestam atenção básica e secundária a usuá rios hipertensos.

No munic ípio de Cuiabá, Mato Grosso, há uma estrutura de atenção à saúde organizada de forma hierarquizada por graus de complexidade - o nível básico, o secundário e o terciário. Quatro distritos sanitários comportam essa rede de atenção: os distritos Norte, Sul, Leste e Centro-Oeste sendo que neles, sob a dministração pública, estão contidos, entre outras unidades, 35 Centros de Saúde, 5 Polic línicas e 1 Centro de Especialidades.

O critério de escolha da unidade foi o de que nela deveria haver profissiona is de saúde que prestassem atendimento ao usuário hipertenso. A fim de que pudéssemos certificar se a unidade pretendida atendia a esse critério, procedemos da seguinte maneira: obtivemos nas secretarias de saúde do município e do estado uma lista das unidades. Depois, estabelecemos contato telefônico com o (a) gerente da unidade perguntando se havia atendimento regular ao usuário hipertenso. Caso a resposta fosse positiva, comparecíamos à unidade para contatar com os profissionais de saúde e os usuários e convidá-los a participar da pesquisa.

Após consideramos que já havíamos obtido dados suficientes para o alcance dos objetivos propostos por meio da saturação, deixamos de fazer contato com as pessoas das unidades.

Ao todo, dez unidades de saúde pertencentes aos distritos sanitánios Norte, Sul, Leste e Centro-Oeste do município de Cuiabá, Mato Grosso, foram incluídos na pesquisa - 3 Policlínicas, 6 Centros de Saúde e o Centro de Especialidades.

Nessas unidades realizam-se, por meio do trabalho do médico, da enfermeira, do pessoal de enfermagem [auxiliares e técnicos] e dos agentes comunitários de saúde, algumas ações de prevenção e controle da HA recomendadas no programa do Ministério da Saúde - Plano de Reorganização da Atenção à Hipertensão Arterial e ao Diabetes Mellitus (BRASIL, 2001) - como rastreamento de hipertensos, verificação dos níveis de pressão arterial, agendamento de consultas, encaminhamentos e marcações de exames fomecimento de medicações, consulta de enfermagem [realizada por algumas enfermeiras] e palestras a grupos de hipertensos [rea liza das ocasionalmente por um 
médico em uma das unidades]. Embora na maioria das unidades houvesse enfermeiras, em duas delas, não havia atendimento da enfermeira a o hipertenso.

O usuário interage com o profissional de saúde em situações que compreendem a rotina de atendimento a os usuá rios nas unidades. Há variações de unidade para unidade, mas, geralmente, ele é recebido pelo(a) recepcionista que localiza sua ficha. Dependendo do objetivo da sua procura à unidade, o usuário é atendido no mesmo dia ou terá uma consulta agendada para outro dia. No dia da consulta, ele é encaminhado ao pessoal de enfermagem que irá realizar os procedimentos básicos como a verificação da PA e do peso e o encaminhará à consulta com a enfermeira, quando houver, e com o médico. Depois disso, ele é encaminhado à farmácia para receber a medicação prescrita e ao(à) secretário(a) que marcará os exames, os encaminhamentos e agenda rá o retomo.

O cadastramento do usuário hipertenso no programa de atenção à hipertensão arterial e ao diabetes mellitus [Plano de Reorganização da Atenção à Hipertensão Arterial e a o Diabetes Mellitus (BRASIL, 2001)] é feito pela enfemeira. Neste cadastramento consta a identific ação do usuário (como pessoa e cidadão), seus dados clínic ose o tratamento que está fazendo.

\subsubsection{Instrumento de coleta de dados}

A coleta de dadosé a descoberta e a reunião - ou produção - de materiais que o pesquisador irá a nalisar. Existem diversos ma teria is [dados], como entrevistas, transcrições de encontros, observações de campo, vídeos, diários, cartas, documentos, respostas a questionários, entre outros, que fomecem dados indispensáveis para a pesquisa social.

Inicialmente pensamos em obter os da dos por meio da observação direta do profissional de saúde e o usuário em interação. Entretanto, optamos por descartá-lo em razão de considerarmos que a presença da pesquisadora na interação afetaria a fidedignidade dos dados coletados, uma vez que se tratava de uma situação restrita, na maioria das vezes, a duas pessoas.

De outro modo, consideramos que para apreender o ponto de vista do profissional de saúde e do usuário sobre a interação que ocorre entre elese, a partir daí, obter dados que nos levassem a compreender de que forma essa interação 
contribuía para a não-adesão ao regime terapêutico, a entrevista seria o instrumento de coleta de dadosadequado para esse fim.

Tal instrumento foi utiliza do como "facilitador de abertura, de ampliação e de aprofundamento da comunicação" (MINAYO, 1993, p. 99) entre os participantes e a pesquisadora.

Assim, foram realizadas entrevistas semidingidas, tanto com o profissional quanto com o usuário, nas quais puderam falar livremente sobre o tema da pesquisa, expressando toda a subjetividade contida em sua visão da interação.

Os roteiros para as entrevistas continham inicialmente algumas perguntas abertas que ajudaram a direcionar o diálogo com os participantes da pesquisa. Como o método prevê, posteriomente algumas questões foram reformuladas e outras acrescentadas a fim de que novos dados fossem obtidos para elucidar os pressupostos levantados na pesquisa. Os roteiros fina is das entrevistas enc ontram-se nos APÊNDICES A e B.

\subsubsection{Procedimentos Éticos}

De acordo com os preceitos éticos vigentes, cumprimos com os requisitos solicitados pelo Comitê de Ética em Pesquisa (CEP) do Hospital Universitário J úlio Müller (HUJ M), em Cuiabá, órgão responsável pela análise e aprovação deste projeto (ANEXO A), mantendo a observância das nomas éticas contidas na Resolução 196/96 do Conselho Nacional de Saúde (CNS), entre elas, o consentimento informado e esclarecido de cada participante (APÊNDICE C) e a solic itação do consentimento da instituição para a realização da pesquisa.

\subsubsection{Estudo Piloto}

Antes da realização das entrevistas definitivas, foi efetuado um estudo piloto com dois profissionais de saúde [uma enfermeira e um médico] e um usuánio. Esse teste nos permitiu perceber que algumas perguntas não estavam bem formuladas levando a dificuldades de compreensão e dupla interpretação por parte dos 
participantes. Neste sentido, procedemos à nova elaboração das questões, refinando a ssim os roteiros das entrevistas.

\subsubsection{Partic ipantes da pesquisa}

Segundo Glasere Strauss (1967), o critério básic o que determina a seleção de grupos para a pesquisa, quando se utiliza a Teoria Fundamentada nos Dados, é a relevância teórica. O pesquisador escolhe os grupos de pessoas que o ajudarão a produzir o maior número de categonias que possibilitarão a compreensão do fenômeno. Ele não pode dizer o número total e os tipos de grupos dos quais coletará osdados até que a pesquisa seja completada.

Este trabalho de pesquisa focalizou as interações entre o profissional de saúde e o usuário hipertenso. Em 25 anos de formada, ao longo da nossa vida profissional e também por outros tipos de experiência, presenciamos muitas interações entre eles. Tal premogativa permitiu-nos acreditar que esses grupos poderiam ajudar na captação de elementos desta interação que nos possibilita riam ir a lém da suposição e trazer dados conc retos para a nalisá-la.

Assim, profissionais de saúde - enfermeiros, médicos e pessoal de enfermagem [auxiliares e técnicos] - que trabalhavam em unidades de saúde interagindo com hipertensos, foram convidados a participar da pesquisa. Durante uma visita que fizemos ao local de trabalho dos profissionais, foi efetuada uma breve explanação sobre o tema da investigação e seus objetivos, bem como do procedimento que seria empregado para a obtenção dos dados, a entrevista, para a qual pedimos a colaboração deles. Foi considerado participante o profissional que aceitou participar da pesquisa.

Outro grupo que mostrou ser de relevância teórica para o estudo foi o dos usuários hipertensos. Os critérios de inclusão dos usuários na pesquisa foram os seguintes: ser adulto [idade acima de 18 anos], hipertenso e ter tido um relacionamento de assistência à saúde com profissionais de saúde há, pelo menos, um ano. Os usuá rios foram escolhidos de forma aleatória. No momento de espera da consulta eram abordados pela pesquisadora, os objetivos do estudo eram explicados a eles e, era feito o convite para participar da pesquisa. Com aquele 
que se dispunha a conceder a entrevista, era marcado um encontro em sua casa, no dia e horário que fosse mais cômodo para ele.

Todos os profissionais de saúde convidados a participar da pesquisa aceitaram ser incluídos no estudo, porém um deles, mais tarde, declinou sua participação por não encontrar um horário em sua agenda de trabalho. Da mesma forma, todos os usuários convidados concordaram em tomar parte da pesquisa, entretanto, um deles, por motivo não muito claro, no momento da entrevista, declinou.

Os participantes foram, no decorrer da investigação, inseridos num processo de inclusão progressiva deteminado pela necessidade de produzir novos dados que levassem à melhor compreensão da realidade estudada, ou seja, à medida que fazíamos as entrevistas, as a na lisávamose, a partir daí, íamos à busca de outros usuários e profissionais de saúde que pudessem fomecer novos dados que tomassem ma is claros os objetivos que quería mos alc ançar.

Ao final, foram computados quinze (15) profissionais de saúde que participaram da pesquisa - seis enfemeiras, seis médicos, uma técnica de enfemagem e duas a uxiliares de enfermagem. A idade desses profissiona is variou entre 29 e 54 anose o tempo de formação entre 3 e 30 anos. Havia no grupo cinco pessoas sem especialização, duas especializadas em Cardiologia, três em Saúde Pública, um em Medicina Social, um em Clínica Médica, um em Cirurgia Geral, um em Hematologia e um em Saúde da Criança e do Adolescente. O tempo de atuação com hipertensos variava entre 6 meses e 24 anos.

Partic iparam também dez (10) usuários, quatro deles do sexo masculino e seis do sexo feminino, com idade entre 42 e 72 anos, a maioria delescasados ou viúvos. Três eram analfabetos, dois tinham o primeiro grau completo e dois o incompleto, dois tinham o segundo grau completo e um o incompleto. Havia entre eles aposentados, trabalhadores autônomos e mulheres que trabalhavam em casa. Sabem que são hipertensos num tempo que varia de 1 a 20 anos, sendo que a maioria fazo tratamento desde que soube do diagnóstico. 


\subsubsection{Coleta dos dados}

A fim de que os participantes se sentissem mais confortáveis, a escolha do local onde a entrevista seria realizada foi deixada a critério deles. Assim, a maioria dos profissionais escolheu seu local de trabalho, enquanto que todos os usuários preferiram conceder a entrevista em suas casas.

Depois da explicação dos objetivos e procedimentos da pesquisa aos participantes, bem como dos seus direitos e, após obter deles o consentimento por escrito, conduzimos as entrevistas que transcorreram num período de tempo de, aproximadamente, 40 minutos cada uma.

Para conseguir reduzir as possibilida des de interpretação subjetiva que, como ser humano, podeńamos ter ao reconstituir as falas dos participantes, todas as entrevistas foram gravadas.

Por ser um método de trabalho contínuo com os dados e por ser a partir da emergência de evidências que o pesquisador decide qual será seu próximo passo, realizamos as entrevistas intercalando-as com a transcrição, o tratamento dos dados e a análise deles. Esses procedimentos permitiram decidir qua is perguntas deveńamos acrescentar ou refo mular nas entrevistas subseqüentes, qua is pessoas entrevistare em que locais.

A coleta dos dados foi realizada no período de janeiro a agosto de 2003 e foi finalizada quando alcançamos o ponto de saturação, ou seja, quando as entrevistas confimaram o que já havia sido dito nas outras.

Desses procedimentos resultaram 28 entrevistas, realizadas uma vez com cada participante, das qua is as três primeiras foram desc artadas por serem aquelas que fizeram parte do estudo piloto.

\subsubsection{TRATAMENTO E ANÁUSE DOS DADOS}

Os autores da Teoria Fundamentada nos Dados propõem que a explicação teórica do fenômeno seja obtida a partir de um grupo de procedimentos que se constituem em instruções, não regras fixas e fechadas, para o pesquisador orientar- 
se no desenvolvimento da investigação. Esses procedimentos fundamentam-se num tipo de análise que Glasere Strauss (1967) denominam de comparativa.

$\mathrm{Na}$ análise comparativa, os dados são coletados e constantemente comparados entre si, entre eles e os códigos, entre os códigos e os conceitos, entre os conceitose as categoriase assim por diante.

Strauss (1987) diz que, ao longo da pesquisa, três aspectos da análise comparativa são imprescindíveis. A indução, que se refere às ações que levam à descoberta de uma hipótese, a saber, ter uma intuição e, então, transformá-la em hipótese, provisória e condicional. A dedução, que consiste em apreender as implicações que provêem das hipóteses ou seus sistemas mais amplos, com o propósito de verificação. Por fim, a verificação que consiste em descobrir a total ou parcial qualific ação de uma hipótese ou sua negação. Desta forma, osdadose/ou um grupo de dados são constantemente submetidos a questionamentos e hipóteses que, no decorrer da investigação, serão testados, tomando a explic ação teórica cada vez mais densa.

Este tipo de análise rejeita a prática de codificar/categonizar primeiro, depois analisar. Ao invés disso, defende a idéia de que o processo de tratamento dos dados e os processos analític os sejam desenvolvidos concomitantemente. Desta forma, o que ocorre é que quando os procedimentos acabam, a teoria também está pronta, fa ltando a penas desc revê-la (GLASER; STRAUSS, 1967).

Segundo Strauss (1987), os dados obtidos na coleta são indicadores de conceitos, inicialmente provisórios, que o investigador produz por meio da comparação constante. Fazendo comparações entre os indicadores, o pesquisador é forçado a confrontar as similaridades, diferenças e graus de consistência entre eles.

A fim de poder alcançar os objetivos propostos neste estudo, após a coleta inicial dos dados, as entrevistas foram transcritas e os dados foram tratados conforme o que determina o método, ou seja, foram examinados cuidadosamente a fim de encontrar os indicadores empíncos - dados reais, tais como comportamentos ou situações, descritos pelos participantes - e cada dado foi rotulado com um código.

Depois disso, os indicadores foram comparados com os conceitos que emergiram, por meio dos quais buscamos a congruência entre eles e também a 
relação entre os conc eitos. Esta etapa é denominada pelos autores de codificação aberta [open coding]. Nessa codificação os códigos proliferam rapidamente, mas só mais tarde é que o processo de análise contínua começou a reduzir sua produção.

Ao longo do processo, os códigos ficaram saturados e foram colocados em relação com outros códigos, outras categoriase subcategorias. Na medida em que elas foram emergindo, procuramos agrupá-las com a ajuda de um modelo de codificação [coding paradigm] sugerido por Strauss e Corbin (1990), que nos possibilitou sistematizar os dados e relacioná-los de forma mais complexa. Os componentes do modelo [as condições, as interações entre os atores, as estratégias/táticas e as conseqüências] servem como guias que auxiliam o pesquisador a fazer questionamentos, gerar hipóteses e fazer comparações, auxiliando na composição do corpo da teoria. O produto desta etapa foi o agrupamento de categorias em cada componente do modelo.

Dessa forma, colocamos as categorias e subcategorias em grupos que considerávamos ser condições contextuais do fenômeno estudado, condições causa is, condições intervenientes, estra tégiase assim por diante.

Glaser e Strauss (1967) aconselham que o pesquisador faça notas ao longo da investigação - memos - a fim de permitir que ele tenha não apenas o registro de seus pensamentos, raciocínios e idéias, mas que também possa organizar os resultados da análise. Igualmente, as notas permitem ao investigador se situar dentro do processo da pesquisa tendo clareza de onde está e para onde deve ir. "São nas notas que as hipóteses são registradas, comparadas, verificadas, modificadas conforme novos dados vão chegando. São das notas, compiladas e classificadas, que o analista obtém o material para escrever a teoria final" (CHENITZ; SWANSON, 1986, p. 108).

Seguindo essa indicação dosautores, foram feitas a notações durante todo o processo da pesquisa. Esses registros não somente foram úteis na análise dos dados e interpretação dos resultados, como possibilitaram confimar ou rejeitar algumas hipótesesque foram surgindo a o longo da investigação.

O passo seguinte foi a codificação axial [axial coding], que consiste na análise intensa feita em tomo de cada categoria produzida na etapa anterior por meio do modelo de codificação (condições, conseqüências, estratégias, e assim 
pordiante). O propósito dessa etapa é chegar à categoria central [ou categorias] a (s) categoria(s) que é (são) fundamental (is) para a integração da teoria. É a partir dela que o pesquisador constrói a sua explicação teórica. Isso é feito por meio da organização ou artic ula ção constante, contínua, entre os componentes da teoria um processo chamado integração.

Nesta etapa, portanto, todas as categorias e subcategorias a nteriomente encontradas foram continuamente comparadas e analisadas a fim de descobrimos a categoria central. Foi um processo difícil, pois ora uma categoria parecia ser a central ora não, ou às vezes uma categoria parecia fazer parte do grupo das condições, outras vezes do grupo das conseqüências. Nessa etapa também percebemos que tínhamos uma categoria central referente aos dados obtidos com o profissional de saúde e outra que dizia respeito aos dados provindos do usuário.

Por fim, a pós encontrarmos as categorias centrais, as outras categorias e subcategorias, realizamos a codificação seletiva [selective coding] a qual delimita a codificação somente aos códigos/categorias que se relacionam às categorias encontradas na codificação axial. É “o processo de selecionar a categoria central, sistematicamente relacionando-a com outras categorias, validando aquelas relações e completando com categorias que precisam de um refinamento e desenvolvimento adicional" (STRAUSS; CORBIN, 1990, p. 116). O pesquisador identifica uma relação entre as categorias e escreve uma 'estória' que as integra (CRESWEШ, 1998, grifo do a utor).

As categorias centrais foram insistentemente comprovadas por sua relação com as outras categorias que, por sua vez, foram consideradas consistentes com os códigos, que se fundamentam nos dados. Esse processo terminou quando percebemos que nenhum dado adicional surgiria, que só estávamos obtendo dados que se repetiam e que a análise não ma is contribuiria para a descoberta de qualquer coisa nova sobre as categorias. Quando isto ocorreu, concluímos que houve a saturação teórica.

Ao final desse processo de codificação e categorização obtivemos ao todo seis categorias, sendo duas delas as categorias centrais: Conscientização e Administrando o regime terapêutico à sua maneira. As demais categorias representam as condições nas qua is se processa o fenômeno da interação entre o 
profissional de saúde e o usuário hipertenso. Além disso, foram obtidas outras 22 subcategorias que auxiliam na fundamentação das categorias principais.

A categoria central referente aos dados obtidos com o profissional de saúde é Conscientização e suas subcategorias: Tarefa difícil, A concepção, Formas de comunicação e Sempre, sempre, sempre. A categoria central que diz respeito aos dados provindos do usuário é Administrando o regime terapêtico à sua maneira.

A categoria que se refere às condições contextuais é $\mathbf{O}$ contexto da interação e suas subcategorias são: Perspectiva do usuário sobre a interação, 0 vínculo, O profissional de saúde na perspectiva do usuário, Ações do profissional de saúde na interação, Ações do usuário na interação e O manejo da HA.

Razões para conscientizar é a categoria que se refere às condições causa is e suas subcategorias são: A concepção de RT, A concepção sobre a adesão ao RT, Responsabilidade com a adesão ao RT e Usuário que não adere - paciente de nisco.

O usuário na interação e fora dela é a categoria que diz respeito às condições intervenientes e suas subcategorias são: A HA e o RT - conhecimento e aprendizado, Significado do RT e da adesão, Percepção de risco e cura, Espectro do risco e Responsabilidade com a adesão ao RT.

Por fim, a categoria que está relacionada às conseqüências é Efeitos e suas subcategorias são: Reações do profissional de saúde, Caracterização do usuário e Responsabilidade pela não-adesão.

Conforme os autores da Teoria Fundamentada nos Dados preconizam, o próximo e último passo deste processo de tratamento e análise dos dados é a construção de uma teoria sobre o fenômeno que está sendo estudado. Um esquema analítico abstrato de um fenômeno que se relaciona a uma situação partic ular (CRESWELL, 1998).

Dependendo do propósito do investigador, as conclusões finais tiradas no curso da pesquisa podem variarem nível de abstração. A explicação teórica pode ser descritiva se o nível de abstração for menor e, se esse nível for maior, o pesquisador pode a lc ançar uma teoria mais a brangente (STRAUSS, 1987).

Outro aspecto relativo às conclusões fina is é que, segundo Glaser e Strauss (1967), a análise comparativa pode ser usada para produzir dois tipos de teoria: a 
substantiva e a formal. A primeira é desenvolvida para a compreensão de um fenômeno pertencente a uma área empírica, concreta, tal como o cuidado do paciente, as relações raciais e a educação profissional. A segunda, diz respeito a fenômenos compreendidos em uma área mais conceitual, abstrata, como o estigma, a socialização e o poder.

Neste estudo, como o fenômeno pesquisado pertence a uma área empírica, concreta, fizemos uma proposição teóric a substantiva, fundamentada nos dados que coletamos, tratamose analisa mos.

Utilizamos como recurso teórico para analisar os dados que no decorrer da investigação emergiram e interpretar os resultados encontrados, não só o referencial do Interacionismo Simbólico, mas também a literatura.

Igualmente importante foi a utilização de dados da prática, os quais, conforme afima Strauss (1987, p. 11), “consistem não somente no conhecimento téc nico do analista e na sua experiência como pesquisador, mas também em suas experiências pessoais".

Diante do exposto, na parte seguinte será descrita a proposição teóric a que construímos sobre a interação entre o profissional de saúde e o usuário, bem como será apresentado o diagrama que integra todasas categorias. 


\section{PARIE 4 - PROPOSIÇÃO TEÓRICA}

Conforme mencionado, o objetivo da Teoria Fundamentada nos Dados é o desenvolvimento de uma teoria explicativa que ajude na compreensão dos fenômenos socia is e psicológic os (CHENITZ; SWANSON, 1986). Stra uss e Corbin (1990) dizem que uma característica essencial dessa teoria é que ela é a presentada como um processo - uma seqüência de ações / interações interligadas que pertencem a o fenômeno estudado e que dão vida aosdados.

O pesquisador, ao apresentar sua proposição teórica deve mostrar a evolução natural dos eventos apontando o porquê e como as ações / interações, na forma desses eventos, feitos, acontecimentos, mudam, permanecem os mesmos ou regridem em face de deteminadas condições; por que há progressão dos eventos, o que leva à sua continuidade e que conseqüências advém desses movimentos (STRAUSS; CORBIN, 1990).

O processo não é para ser visto necessariamente como os dados em si, porque não se pode capturar todas as mudanças e movimentos que ocorrem na realidade, mas como parte de uma realidade empírica (STRAUSS; CORBIN, 1990).

A idéia de teoria como processo advém do fato de que ela não é para ser considerada como um produto perfeito, mas como um produto momentâneo, em constante desenvolvimento (GLASER; STRAUSS, 1967).

Em tese, a explicação teóric a que o pesquisador dá ao fenômeno estudado, não deveria ter fim. Entretanto, por se tratar de um estudo que necessariamente obedece a um prazo, na prática, de acordo com Strauss e Corbin (1990), seu témino dependerá do tempo, energia e experiência do pesquisador.

Isto posto, nesta parte do trabalho, será descrita a construção teórica que está fundamentada nos dados que foram coletados, tratados, analisados e interpretados. Ela demonstra a compreensão que tivemos sobre a interação entre o profissional de saúde e o usuário a partir de suas perspectivas. A compreensão da interação possibilitou-nos o alcance do segundo objetivo desta pesquisa, ou seja, analisar de que forma a interação entre o profissional de saúde e o usuário hipertenso contribui para a não-adesão a o RT.

A apresentação da proposição teórica será feita por seqüência de categorias e subcategorias [demonstrando o seu caráter processual] que representam os elementos do processo de interação entre o profissional de saúde e 
o usuário, deles com eles mesmos e deles com outros objetos que, quando se fizer necessário, serão ilustrados com fragmentos dos relatos dos participantes [identificados com a letra $P$, quando se tratar de profissional e $C$, quando for o relato de um usuário. O número subseqüente corresponde ao número da entrevista].

A proposição teórica também poderá ser visualizada em um diagrama por meio do qual está representada a inter-relação das categorias centrais com as outras categoriase subcategorias (Fig. 1). 


\section{O CONTEXTO DA INIERAÇÃO}

- Perspectiva do usuário sobre a interação com o profissional de saúde

- O vínculo

- O profissional de saúde na perspectiva do usuário

- Ações do profissional de saúde na interação

- Ações do usuário na interação

- O manejo da HA

$\Rightarrow$ Más condições de trabalho

$\checkmark \quad$ Tipologia do usuário

$\Rightarrow$ A percepção do problema

\section{RAZÕES PARA CONSCIENTIZAR}

- A concepção de regime terapêutico

- A concepção sobre a adesão ao RT

- Responsabilidade com a adesão ao RT

- Usuário que não adere - paciente de risco
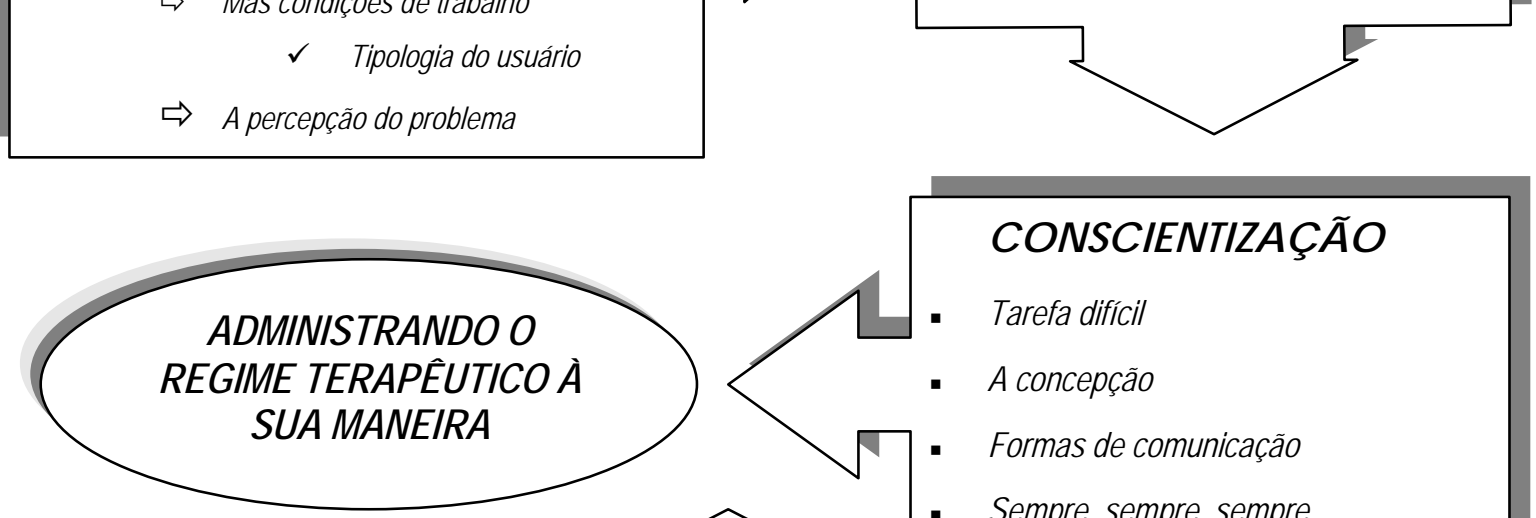

\section{CONSCIENIIZAÇÃO}

- Tarefa difícil

- A concepção

- Formas de comunicação

- Sempre, sempre, sempre

\section{O USUÁRIO NA INTIRAÇÃO E FORA DELA}

- $\quad$ A HA e o RT - conhecimento e aprendizado

- Significado do RT e da adesão

- Percepção de risco e cura

- Espectro do risco

- Responsabilidade com a adesão ao RT

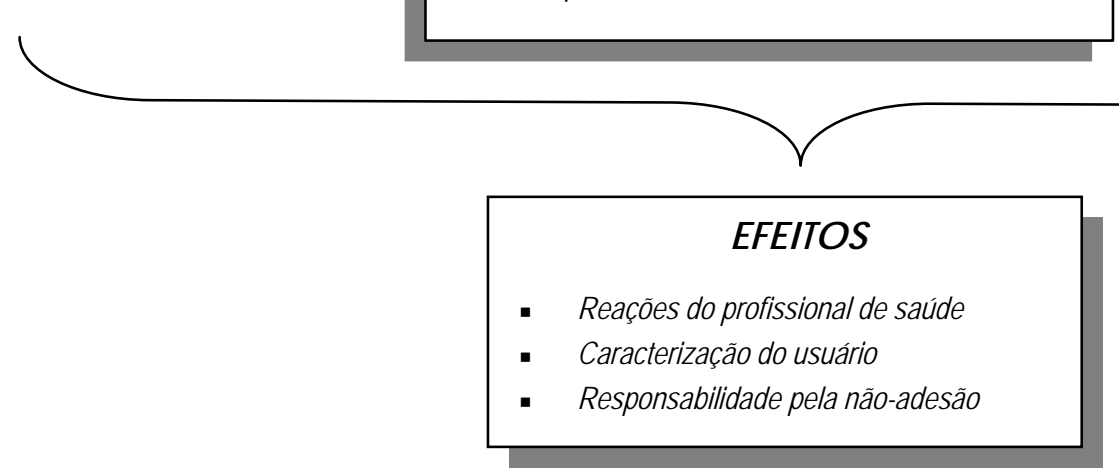

Figura 1 - Proposição teórica sobre a interação entre o profissional de saúde e o usuário. 
De acordo com Charon (2000), muitas ações das pessoas resultam da interação entre elas. Quando agimos, levamos em consideração outra pessoa e ela, por sua vez, quando age, nos leva em consideração. Isso é interação social “cada pessoa é a o mesmo tempo sujeito e objeto, ou seja, cada pessoa, tendo em vista outras, atua como sujeito e por sua vez é considerada objeto por outras" (CHARON, 2000, p. 46). É a interação que direciona nossas idéias, valores, objetivos, interesses, princípios morais, talentos, emoções e tendências para atuar de determinadasmaneiras.

Segundo o autor, a natureza do ser humano é social, pois não se vive no isolamento. Por consideramos as outras pessoas, embora tenhamos a nossa individualida de e liberdade, somos atores socia is agindo em parte como resultado do que elasfazem.

Profissional de saúde e usuário são atores sociais que interagem numa situação de saúde/doença. Ambos entram na interação com algumas coisas definidas, advindas de diferentes histórias de interação, tanto no atendimento público quanto no privado, e de algumas experiências passadas em suas vidas. Ambos agem em direção a si e em direção ao outro, indicando elementos que contribuem para a definição que cada um faz da situação, incluindo suas perspec tivas, gestos, self, motiva ções, linguagem, que resultam nos a tos socia is.

\subsection{0 contexto da interação}

\subsubsection{Perspectiva do usuánio sobre a interação com o profissional de saúde}

Os usuários, participantes desta pesquisa, revelam sua perspectiva sobre a interação entre ele e o profissional de saúde, obtida a partir das experiências de atendimento que tiveram. De acordo com os usuários, há três tipos de interação: com o profissional que não se interessa por ele; com o profissional que o atende cordialmente e com o profissional que se interessa porele.

O primeiro tipo é aquele no qual o profissional de saúde, entre outras coisas, não se interessa por ele, por seu caso ou por sua vida pessoal; não olha nos seus 
olhos, não o escuta, não o toca, não dialoga com ele, não responde às suas perguntas, atende-o muito rápido e o trata de forma grosseira e/ou agressiva.

\begin{abstract}
“É, eu penso assim... Que os médicos da saúde... Alguns, não vou falar todos, eles só olham na cara do paciente e falam - 'O que é que você tem? '. Falo - 'Ah, tenho isso, isso e isso'. E ele - 'Ah, tá bom'. Já pegam a caneta, já escrevem e - 'Tá aí a receita. Vai a tal lugar'. Não pegam aparelho para medir, [não perguntam] se a pessoa tem ou não tem alguma coisa. Nada." (C 5)
\end{abstract}

“...tem muitas enfermeiras estúpidas, estúpidas mesmo.” (C 9)

Nesse tipo de interação o usuário sente-se insatisfeito, desestimulado, desinteressado, tenso e até tem vontade de não ma is retomarà consulta.

\footnotetext{
“Eu que não sou assim de responder nada, tudo que falam eu fico quieta porque eu preciso, né. [...] Porque se a gente vai ao médico, a gente já está doente e a gente chegar lá e encontra desde as enfermeiras tratando a gente mal, a gente sai de lá mais doente ainda." (C 9)
}

“Ah! É homível! Dá vontade de levantar e sair. Dá vontade de não voltar mais" (C 4)

“Desestimula porque a pessoa não tem interesse em fazer o tratamento porque chega lá o médico nem olha para você." (C 5)

Este tipo de insatisfação que também foi constatada por Santos e Lacerda (1999) a o realizarem uma pesquisa com usuários atendidos pelo SUS. Segundo os autores, $90 \%$ dos usuários estavam insatiffeitos com a falta de atenção e de informações prestadas pelo médico que apenas eventualmente acontecia e de forma muito rápida, não satisfazendo as suas expectativas quanto à doença e ao processo de recuperação, o que os deixava inseguros e com muitas dúvidas.

O segundo tipo de interação é o mais freqüente no cotidiano da assistência à sua saúde. Não é a que mais lhe satisfaz, mas é aquela com a qual ele se conforma, pois o profissional de saúde o atende com cordialidade, embora desenvolvendo ações que se limitam a questionamentos sobre sina is e sintomas e sobre o seguimento do RT, à prescrição de medicamentos, pedidos de exames e encaminhamentos. 
“Não, eu não tenho o que dizer. Graças a Deus, todas as vezes que eu vou, eu sou bem atendida. [...] Ah! Porque eles atendem a gente direito, com delicadeza. Eu acho que bem atendida é isso. [...] Se a gente precisa de outro médico a gente pede para ele encaminhar, ele encaminha." (C 4)

O terceiro tipo de interação é a quele que mais lhe agrada e que ele gostaria de ter ma is freqüentemente. Uma interação na qual há mais diálogo e interesse do profissional de saúde por ele, porsua saúde e por sua vida.

“Porque se a gente for fazer uma consulta mesmo todo mês, adequada mesmo, seria outro tipo de consulta. Precisaria ter um diálogo bastante com o médico, mas lá não tem... Com o médico do SUS você não tem diálogo. Chegou, já te mede a pressão e acabou. O diálogo é pouquinho. [...] Atendimento bom é dar atenção para a gente, dar atenção e fazer pergunta - 'Como é que está? '. Esse é um bom atendimento. Saber da vida da gente, como que está passando. Agora, se o médico não procurar perguntar nada é porque também ele não está se interessando pelo usuánio dele. Então, ele tem que perguntar. Fazer bastante perguntas para a pessoa fic ar satisfeita e acharque o médic o está se interessando por ele." (C 21)

"Ah! Eu acho assim, o médico tem que escutar o que a gente tem, o que a gente vai falar, o que a gente está sentindo, né? Então, a gente tem que falarcom o médico. Ele tem que saber o que a gente tem." (C 4)

As interações desse terceiro tipo são mais raras, evocadas das lembranças do usuário em algum momento de sua vida como hipertenso interagindo com um profissional de saúde.

"São dois médicos de posto de saúde que têm uma paciência enome com os pacientes. Por ma is que eles tenham a agenda a cumprir, eles têm muito tempo para dar para a gente. [...] Mas eles fazem com que a gente fique à vontade e possa perguntaro que deve." (C 11)

“Eles explicavam qual o motivo de a gente não poder estar passando nervoso; conversavam com a gente - 'O que está acontecendo, dona M., que a Sra. está nervosa? A pressão da Sra. está subindo. O que está 
acontec endo na casa [da senhora]?'. Eles preocupavam, queriam saber o que estava acontec endo e a gente falava, conversava." (C 9)

Como se vê, esses resultados realçam a importância que o usuário tende a colocar sobre a interação entre ele e o profissional de saúde. Longe de ser totalmente passivo, o usuário está atento às atitudes e comportamentos do profissional de saúde na interação, buscando elementos para julgá-la satisfatória ou não.

Dos profissionais de saúde eles esperam interesse e acolhimento. Uma interação na qual o profissional lhe dá atenção se interessando por ele e por seu caso, despendendo tempo com ele, conversando, ouvindo-o, olhando-o nos olhos e tocando-o. Esperam encontrar um profissional que atenda às suas necessidades biológic as [alívio de sintomas], a ssim como a os seus anseios de querer falar de suas queixas e seus problemas, ou seja, aquele que transmite confiança e tem paciência com ele, respondendo às suas perguntas com respeito e consideração. Além disso, esperam que ele seja um profissional que se importa com suas necessidades mais imediatas como a obtenção da prescrição de medicamentos, de pedidos de examese de encaminhamento.

Esses resultados são congruentes com um dos achados de Traverso-Yépez e Mora is (2004) que, quando realizaram um estudo com usuários de distritos sanitánios da rede básica de saúde, observaram que eles, de modo geral, têm a expectativa de que o profissional de saúde gere uma situação de acolhimento que alivie ou amenize seu sofrimento e que possa responder resolutivamente ao seu problema.

\subsubsection{O vínculo}

Os profissionais de saúde, participantes desta pesquisa, revelam nos seus relatos que sabem que o usuário espera ser bem atendido por ele na interação e pelo serviço de saúde.

\footnotetext{
“Eles querem é isso. Por exemplo, eles querem que os médicos sejam mais acessíveis, pois na rede ainda está pouco. [...] Eles querem às vezes falar conosc o. [...] Ser bem atendidos... Dar um somiso para eles... Porque às vezes ele tem mil problemas lá e chega no lugare é mal atendido; aí ele fica pior. Às vezes eles não estão doentes, o que eles querem é ouvir de nós que
} 
trabalhamos na área da saúde, alguma palavra de conforto para eles". ( $P$ 19)

O seguinte relato demonstra que o profissional também considera que deve atender bem o usuário, o que para ele significa não se colocar em posição de superionidade ou de distância em relação a o usuário, não deixar de dar atenção a ele, mal olhando-o, sem conversar com ele ou fomecendo-lhe explicações. Significa também tratá-lo com igualdade e respeito, despender tempo conversando com ele, escutando-o, deixando-o à vontade para fazer perguntas e tirar dúvidas.

\footnotetext{
“Não pode ter um relacionamento em que o usuário não se sinta à vontade, às vezes, de perguntar, tirar dúvidas". (P 16)

“Então, a relação entre o médico e o paciente, a enfermeira e o paciente, é muito importante sim porque, de repente o paciente chega aqui e a enfermeira só olha para a cara dele e diz - 'Olha, o Srvai tomarisso, isso, isso. Pronto. Tchau'. Não, não é bem assim. [...] Aí ele não vai ter aquela confiança, coitado, ele não vai mais voltar lá. - 'A enfermeira, o médico, não olha nem para a minha cara! Ele não está nem sabendo qual é o meu problema'". (P 15)
}

Como se vê, esses resultados mostram que o profissional de saúde também tende a dar importância para a interação entre ele e o usuário. Realçam igualmente que ele compartilha com o usuário a perspectiva de que nela é necessário que o profissional desenvolva um conjunto de atitudes e comportamentos em relação ao primeiro, para que seja satisfatória. No seu entendimento, isso depende muito mais dele do que do usuário.

\footnotetext{
“Então, isso é tarefa nossa. Se eu não receber bem a pessoa, se eu não estabelecer com ela uma relação de diálogo, de confiança, eu não estou cumprindo a tarefa..." . (P 12)
}

Para o profissional, as atitudes e comportamentos que ele tem que desenvolver na interação com o usuário são necessários para que se estabeleça uma relação de afinidade entre eles, um vínculo no qual haja confiança e credibilidade. 
“Eu acho que o usuário precisa ter aquela afinidade com o profissional. É igual a um relaciona mento entre marido e mulher." (P 13)

Seu interesse em desenvolver um vínc ulo entre ele e o usuário é muito grande porque é a partir daí que o usuário passa a confiare acreditar nele, no que ele lhe diz.

“Você tem que ter uma confiança na pessoa. Se você não tiver, se o profissional não te passar confiança, não te passar uma segurança de que você vai ter um bom tratamento, se você não tiver um bom relacionamento com o profissional, você não vai acreditar no que ele vai te dizer". (P 13)

Para o profissional de saúde, confiança e credibilidade são elementos essenciais para que o usuário execute a sua prescrição e faça a quilo que ele pensa sero melhor para a sua saúde.

\footnotetext{
"Quando você procura um profissional, qualquer que seja, você não o conhece, mas você vai acreditando, passando a acreditar pelas atitudes da relação de uma pessoa com a outra, naquilo que você acredita, naquilo que ele olhando nos seus olhos, diz - 'É assim e tem que ser assim. O melhor para você é assim'. [...] ....a partir da hora que o paciente confia em você, ele faz, executa exatamente aquilo que você pede, acreditando que você está fazendo o melhor porele". (P 26)
}

O profissional acredita que ao executar o que ele prescreve, o usuário estará, conseqüentemente aderindo a o RT, o que, no seu entendimento, garante o sucesso do tratamento. Sucesso que, como será visto, mais adiante, é importante para ele.

\footnotetext{
“E essa tarefa [o vínculo] é essencial para o sucesso do tratamento porque a confiança e a consciência no processo todo é fundamental para o sucesso. A confiança se estabelece na relação, então, tem que ser uma relação que gere confiança. Tem que ser uma relação de vínculo mesmo. E é o vínculo, é o diálogo que me permite criar as condições para que a pessoa tenha a compreensão mais inteira do seu problema, para que ele possa fazer a sua parte no tratamento. Então, isso é fundamental". (P 12)
} 
Como é possível perceber, esses resultados realçam a importância que tanto o profissional de saúde quanto o usuário tendem a colocar sobre a interação entre eles. Destacam também que ambos compartilham a perspectiva de que na interação é necessário que o profissional desenvolva um conjunto de atitudes e comportamentos para que ela seja satisfatória. Embora nos seus relatos o usuário não faça referência à confiança, está implícito que o acolhimento efetivo gera confiança e vice-versa.

Tal afimação é sustentada pelos achados de Lupton (1997, p. 376) que entrevistou 60 pessoas pesquisando, entre outras coisas, suas experiências de interação com médicos a o longo de suas vidas. Um de seus resultados foi que os participantes se importavam mais com a forma como os profissionais interagiam com eles e os julgavam severamente se sentissem que tinham sido mal tratados, argumentando que esses profissionais não poderiam ter a confiança de alguém que buscava cuidado para sua saúde.

Entretanto, é importante destacarque para o usuário importa perceber que o profissional de saúde se interessa por ele como pessoa. De modo diferente,o profissional quer que o usuário se interesse pelo que ele lhe diz, que se volte para ele, que focalize a sua atenção nele e no que ele tem para lhe dizer, seja o que e como for.

Diferente da idéia de reciprocidade que toda interação deve ter, o profissional de saúde tem uma perspectiva na qual ele é colocado em um papel central, enquanto o usuário desempenha um papel periférico. Na sua visão, a interação se processa principalmente na direção usuário $\rightarrow$ profissional de saúde. Como é fác il concluir, isso produz um desequilíbrio na relação, gera assimetria.

Do exposto até aqui, é possível inferir que do ponto de vista do profissional de saúde a interação entre ele e o usuário é fundamental para a a desão a o RT.

\subsubsection{O profissional de saúde na perspectiva do usuánio}

O médico, a enfermeira e também o pessoal de enfermagem - técnicos e auxiliares - profissionais de saúde que interagem com o usuário hipertenso na atenção básica, são percebidos por ele levando-se em consideração, principalmente, as atividades cotidianas que rea liza $m$. 
O pessoal de enfermagem é percebido pelo usuário como um grupo de funcionários que dá apoio ao trabalho do médico, responsável por agendar as consultas e fomeceras medicações, medir a PA.

\footnotetext{
"As pessoas que atendem a gente no posto lá, elas atendem nós quando chegamos... Não são enfermeiros, essas pessoas não são enfermeiros. São simplesmente funcionários para fazer a orientação que os médicos passam para eles a té chegara vez de semos consultados." (P 21)
}

A enfermeira é percebida pelo usuário como uma profissional que faz parte desse grupo, rea lizando a tividades igua is à s de seus componentes, sem distinção de função. Resultado semelhante foi encontrado por Barbosa et al. (2004) numa pesquisa que tinha como um dos objetivos identificar as percepções dos gerentes, usuários e gestores de saúde sobre a contribuição do trabalho do enfemeiro em unidades básicas de saúde. Segundo os autores, os usuários viam a atuação do enfemeiro baseada apenas em procedimentos básicos e técnicos, não o distinguiam dos demais profissionais da equipe de enfermagem e não o visua liza vam coordenando os programas ou fazend o palestras educ a tivas.

Nesta pesquisa, o usuário considera a enfermeira uma boa pessoa e boa profissional, mas que está abaixo do médico hierarquicamente, realizando atividades que ele determina.

“O enfermeiro é a segunda pessoa [depois] do médico. É um conselheiro também para a gente." (C 17)

"O enfermeiro é o enfermeiro. Que cuida do paciente pela orientação do médico. [...] Ele fazo que o médico fala, o que ele manda fazer." (C 22)

Igualmente Bastos (2002), em sua investigação com hipertensos, na qual quis saber qual era a visão que eles tinham sobre a enfermeira, descobriu que para os participantes, ela era uma pessoa que, hierarquicamente, estava disposta depois do médico.

De outro modo, a perspectiva do usuário sobre o médico possui dois componentes: o profissional e o pessoal. Em termos profissionais, ele é visto como alguém com formação superior, especialista e que, portanto, tem conhecimento. Mas, também é visto como uma pessoa igual a ele. 
“Eu vejo o médico como uma pessoa humana igual a mim e um profissional na área dele." (C 21)

“... pode vacilartambém, não é.” (C 23).

Como os participantes deste estudo, as pessoas pesquisadas por Lupton (1997) expressaram que reconheciam o conhecimento médico como verdadeiro, mas também reconheciam que o médico não era como santo, mas tão humano quanto qualquer outra pessoa.

Diferente dos outros participantes, um usuário confere ao médico o status de salvador e mantenedor da vida dele, demonstrando submissão incondicional ao profissional.

\footnotetext{
“Ele representa para mim... Ele é o meu salvador porque ele estudou aquilo, ele sabe o que eu tenho. Então, se eu agarrar com ele e tomar os medicamentos, eu vou viver até quando Deus quiser porque aqui na terra é nele que eu tenho que ter confiança." (C 17)
}

Dos relatos dos participantes pudemos apreender que, para o usuário, a principal referência, quando se trata do atendimento ao hipertenso, é o médico, sendo a enfermagem, particularmente o enfermeiro, um elemento secundário, às vezes, nem lembrado no conjunto da assistência.

“Não, da parte da enfermagem não. Só o médico mesmo que conversa, fala que tem que fazer o tratamento mesmo, senão... E tomar o remédio e o controle do sal na alimentação." (C 11)

“Enfermeiro? Não, nunca. (...) Não, não. O médico que media a pressão. (...) É o que eu estou falando. Enfermagem, nenhuma. (...) E não tive acompanhamento de ninguém para medir minha pressão, por semana, nada, nada. Não tive acompanhamento nenhum. (...) Nenhum, da enfermagem nenhum." (C 5)

Esse a cha do foi igualmente enc ontra do por Stuchi (1999) que, a o a nalisar as crenças de autoridade emitidas por portadores de doença corona ria na, consta tou que eles reconheciam como autoridade, os médic os e os familiares, enqua nto que 
o enfemeiro sequer foi mencionado. Muñoz et al. (2003), em estudo desenvolvido com portadores de Hipertensã o Arterial, Diabetes e Artrose, também evidenciaram que as enfermeiras que atendiam os hipertensos tinham pouca visibilidade.

Embora não seja a principal referência do usuário na atenção básica ao hipertenso, a enfermeira, em algumas situações, foi vista por alguns deles sob outra perspectiva. Eles a diferenciaram não apenas do pessoal de enfemagem, como, também, do médico. A primeira delas foi quando o usuário esteve em situações de crise e foi atendido por ela de forma competente e acolhedora.

\footnotetext{
"Aí a enfermeira pegou a receita dele, olhou e falou - 'Hum! Está muito alta!'. Aí ela veio, mandou que eu sentasse e colocou um comprimido embaixo da minha língua. Enquanto isso, ela ficou ali conversando comigo dizendo que essa parte é muito perigosa, que tem que ter paciência, não posso ter contrariedade, não posso fic ar nervoso porque, conforme o choque, em vez da pressão abaixar, sobe mais rápido." (C 23)
}

A segunda situa ção foi quando ele foi atendido pela enfermeira em uma consulta de enfermagem. Por causa desse atendimento, ele a identificou como uma profissional diferente do conjunto de profissionais da enfermagem, reconhecendo sua formação e conhecimento.

\footnotetext{
"Agora, tem enfermeiro que sabe muitas coisas, ele formou para aquilo. [...] Tem enfermeiro que é bom. Tem muitos enfemeiros que falam para os pacientes. A enfermeira fala que isso aí vai fazer mal para você... [...] Tem essa enfermeira deste posto. Ela é muito atenciosa, muito atenciosa mesmo. Ela cuida bem dos pacientes hipertensos, diabéticos. Ela é só para isso ali. [...] Eu acho ótimo o tra tamento que eu faço com ela. Eu acho ótimo. [...] Ela também é muito boa. [...] É uma boa enfermeira para os pacientes. Ela orienta bem, dá os remédios certos, manda fazer exames de laboratório." (C 22)
}

Esses a chados se assemelham ao de Barbosa et al. (2004) que nos relatos de alguns usuánios puderam constatar que eles reconheciam o trabalho da enfermagem quando executavam ações de profilaxia e prevenção.

É possível perceber novamente que para o usuário hipertenso, o atendimento competente e acolhedor é um elemento importante na interação, inclusive como fator de diferenciação entre os profissiona is de saúde. 
Da mesma forma, é possível perceber que o usuário também confere ao profissional de saúde, principalmente o médico, o papel central na interação.

\subsubsection{Ações do profissional de saúde na interação}

Para o profissional de saúde, a HA é uma doença séria, incurável, que gera complicações importantes. A fim de mantê-la controlada e evitar que o usuário tenha complicações, um conjunto de ações é desenvolvido por ele na interação. Essas ações são recomendações dos protocolos estabelecidos nos consensos nacionais e intemacionais e no programa do Ministério da Saúde - Plano de Reorganização da Atenção à Hipertensão Arterial e ao Diabetes Mellitus (BRASIL, 2001).

Segundo os relatos dos médicos, na interação com o usuário, basicamente suas ações são: levantamento de dados sobre o usuário hipertenso e sua doença, exame físico, prescrição de medicamentose medidas não famacológicas, pedidos de exames, encaminhamentos para outros profissionais, explicações sobre a medicação, sobre a HA e suas complicações.

\footnotetext{
"A gente segue mais ou menos a planilha que existe, o protocolo que existe. Em primeiro lugar, investigação de causas, secundariamente mudanças de hábito de vida, eventualmente orientação nutricional dentro das nec essidadese, em último caso, medicação,..." (P 18)
}

A maioria das enfermeiras relata que realizam a consulta de enfermagem na qual suas ações são: falar ao usuário sobre a HA e suas complic ações, mensuração da pressão arterial, peso, altura, explicações sobre a medicação e encaminhamentos do usuário para o médico e para a nutricionista. Uma enfermeira disse que realiza levantamento de dados sobre o usuário, sua doença e o tratamento.

\footnotetext{
“Faço consulta de enfermagem. A gente começa através de verificação de PA, nós verificamosa PA. Na interação com o paciente a gente já conversa com ele: Se ele já é hipertenso? Se ele toma medicamentos? Desde quando? E se ele foi orientado quanto à dieta. Dar acompanhamento constante, fazer verific ação da PA constante porque essa pessoa hipertensa tem que ter um acompanhamento semanal ou a cada dois dias, verificar a
} 
pressão, ficar sempre em contato com ele para a gente ter um controle, para evitar seqüelas. “ (P 15)

Pelos relatos, é possível perceber que a enfermeira chama de consulta de enfermagem às ações que são mera repetição das ações do médico, um trabalho sem muita resolutividade, pois é feito de maneira desorganizada, sem uma adequada avaliação da saúde do usuário, sem diagnóstico das respostas do usuário ao seu problema de saúde, sem estabelecimento de objetivos e metas, e sem uma a propriada a valiação dos resultados obtidos.

O pessoal de enfermagem [técnicos e auxiliares de enfermagem] refere que realiza agendamento das consultas e exames, e as mesmas atividades da enfemeira, exceto o levantamento de dados.

Além dessas ações, outras são comuns a todos os profissionais de saúde pesquisados e demonstram suas preocupações com a adesão do usuário ao RT. Eles relatam que constantemente checam se o usuário está tomando a medicação, se está seguindo a dieta recomendada e fazendo exercícios. Ainda relatam que o orientam sobre a necessidade de tomar a medicação, controlar o peso e o sal, não se alimentar de comida gordurosa, ficar mais calmo, medir a pressão arterial, comparecer às consultas, não abandonar o tratamento, entre outras.

Toda vez que o paciente chega a gente já pergunta: 'Como vai a dieta? Está tomando o remédio direitinho? Está fazendo os exercícios? Já procurou o médico esse mês para consultar, para ver se você vai continuar tomando a dose do medicamento certo ou continuar com o mesmo medicamento?' Então, a gente bate bem em cima disso." (P 15)

Sob a ótica do usuário, no âmbito da interação, as ações do profissional de saúde compreendem perguntas sobre seu estado de saúde e suas queixas, sobre o seguimento das suas recomendações e sobre o controle da PA. Na concepção do usuário, o profissional faz essas perguntas porque quer saber como está seu estado de saúde e porque quervê-lo melhor.

Segundo o usuário, o profissional também mede a sua PA, prescreve os medicamentos ou reajusta a dosagem e faz pedidos de exames. Além disso, fala para ele o que deve ser feito para manter a HA controlada e evitar complicações, 
que são as recomendações sobre dieta, exercícios, estresse, fumo, bebida, comparecimento às consultas, entre outras.

\begin{abstract}
"Ah, a única coisa é que você entra na sala e o médico vai perguntar porque você está ali. E aí, a partir da li ele vai venificar a sua pressão. A única coisa que eles fazem é diminuir o remédio se ela estiver baixa ou aumenta ro remédio, ou passar outra medicação para que ela possa abaixare voltarao nomal." (C 11)
\end{abstract}

De acordo com o usuário, uma outra ação do profissional de saúde é enfatizar que o RT tem que ser seguido à risca e que ele não pode deixar de seguílo.

\begin{abstract}
Ah, eles costumam falar só, como eu já falei, que eu não posso deixar de tomar o remédio. Eu não posso estarfacilitando. - 'A Sra. não pode deixar de tomar, nem que a Sra. não esteja sentindo nada, mas todo dia a Sra. tem que tomar o remédio, não deixa de tomar o remédio'. Isso que eles falam para mim." (C 9)
\end{abstract}

Conforme o usuário, a enfermeira, a lém de realizar as ações acima descritas, também faz o cadastramento previsto no programa do Ministério da Saúde. E o pessoal de enfermagem, no apoio ao atendimento do médico e da enfemeira, costuma conversar com o usuário, reafimando as deteminações médicas e da enfermeira, a lém de confortá-lo quando a consulta está demorando ou quando ele se sente mal tratado.

\footnotetext{
“Elas falam que é para a gente compreender que tem que ser seguido à risca o que o médico passa sobre a a limentação, sobre a hidroginástica que a gente faz. Tem que seguir. [...] Eu falei - 'Ah! Esse médico...' - 'Não, dona M. não é a ssim. A Sra está enga nada com isso. Então, a Sra tem que seguiro que o médico fala porque senão a Sra não se ajuda.' Porque às vezes eu ia me queixar. E ela dizia - 'Não, não é assim, ele tem esse lado grosso de falar, mas a Sra tem que entender que é para o seu bem.' [...] Geralmente a gente vai ao médico e mostra a receita para elas. Então elas dizem - 'Isso aqui a Sra vai ter que fazer direitinho."' (C 17)
} 
Pode ser observado, tanto nos relatos dos profissiona is como nos dos usuários, que as ações dos profissionais de saúde na interação com o usuário são rotineiras, prescritivas e baseiam-se na visão biomédica da atenção à saúde das pessoas a qual privilegia o biológico em detrimento de outros aspectos igualmente importantes, como os psic ossocia is e culturais. O foco é sobre o corpo e a doença, sobre o RTe a adesão a ele.

A “conversa" (grifo nosso), como às vezes é chamada a interação pelos profissionais participantes, em vez de apresentar-se como um momento em que há espaço para o usuário esclarecer suas dúvidas, obter explicações e relatar suas experiências de convívio com a doença e o RT; e de ser um momento no qual o profissional levanta dados sobre as questões psicossociais, culturais, ambientais e espintuais que invariavelmente estão presentes no processo de vivere conviver com um problema crônico de saúde, de maneira que o ajudem na compreensão do usuário e seu processo de adesão ao RT, ou de potenciais que ele possa ter para serem usadose trabalhados com intervenções educativas, além de demonstrações de acolhimento. Em vez disso, gira em tomo das ações prescritivas que o usuário deve ou deveria realizar.

Na verdade, constata-se que, na maior parte das vezes, na interação ocorre um monólogo do profissional, "que como um pesquisador, dinge e conduz a seu bel-prazer uma conversa aparentemente livre, cujo desenrolar obrigatório vai das perguntas que marcam seu início até às ordens que a teminam" (BOLTANSKI, 1989, p. 59-60).

É evidente que a subjetividade do usuário não está sendo considerada, o que, segundo Tra verso-Yépez e Mora is (2004), traz conseqüências negativas para a interação entre ele e o profissional de saúde, pois ela está quase sempre alicerçada na crença de que é somente este último, e não [ou também] o próprio usuário que sabe a respeito do seu estado de saúde ou doença.

\subsubsection{Ações do usuário na interação}

Segundo os relatos do usuário, no contexto da interação, o que ele faz e diz compreendem respostas ao profissional referentes às perguntas que lhe são feitas sobre seu estado de saúde e sobre o seguimento do RT. Em relação a essas respostas, o usuário relata que algumas são fomecidas sem dific uldade, mas alguns 
alegam ser mais difícil responder a certas questões que lhe são dingidas. Diz que raramente tira dúvidas e que apenas questiona alguma coisa sobre medicamentos e seu estado de saúde.

\footnotetext{
"C: Bom, eu costumo falar para ele o que eu sinto com a doença e ele só me manda fazer o exame, como de praxe, né. [...] Eu falo - 'Estou tomando nos dias certos, nos dias que o Sr marca para tomar o remédio assim... um, dois comprimid os ao dia. Estou tomando'. [...] Respondo as perguntas. Todas que ele faz, eu respondo.

$P:$ Tem alguma que é ma is difícil de responder?

C: Não. Não tem pergunta difícil, não." (C 22)
}

\begin{abstract}
“Às vezes eu faço [perguntas]. Às vezes o médico passa a receita para mim, eu vou e compro o remédio. Aí eu não acho efeito naquele remédio, então eu volto lá com o remédio e pergunto para ele se está certo aquilo que ele passou." (C 23)
\end{abstract}

Sob a perspectiva do profissional de saúde, na interação, as ações do usuá rio resumem-se em responder à s suas perguntas a presentando as queixas físic as e as dificuldades que tem para seguir o RT. Ainda, em solicitar medicamentos e pedidos de exame.

\footnotetext{
“Quando ele vem ele pega remédio por três meses. A receita é contínua, mas todas as vezes que ele vem para a consulta, para pegar o remédio, a reclamação da maioria é: dores de cabeça, cansaço físico, não agüenta andar muito e já sente falta de ar, cansa muito fácil." (P 14)

"A população que nós trabalhamos com ela, geralmente costuma dizer pouco ou quase nada. (...) Quase nada. - 'É difícil emagrecer, doutor'. - 'É difícil parar de fumar'." (P 26)
}

Essa atitude do usuário na interação faz com que ele seja concebido pelo profissional como uma pessoa desinteressada, pois busca no serviço de saúde basicamente os medicamentos, pedidos de exames e encaminhamentos, e como informação, o valor de sua PA. 
"As pessoas vêm aqui no centro de saúde especificamente para pegar remédio ou para medir a pressão,... [...] A pessoa só vem aqui para pegar remédio. [...] As pessoas chegam aqui com a receita para pegar remédio e falam: 'Dr. eu queria que o Sr...'." (P 18)

Do mesmo modo que os participantes desta pesquisa, os profissiona is de saúde do estudo de McGrath (1999) também expressaram que, na sua perspectiva, muitos pacientes necessariamente não querem saber tudo sobre suas prescriçõese, essencialmente, querem que o profissional diga o que há de errado com eles de forma rápida e simples.

Tal comportamento parece ser comum entre os usuários, pois Ferreira (2001) também constatou que a procura para a consulta médica em Unidades Básicas de Saúde é predominantemente para alívio dos sintomas, contrariando as expectativas dos profissionais de saúde de realizar consultas preventivas e de estímulo ao autocuidado.

O que se constata com esses resulta dos é que, por ser menos assertivo e fazer poucas perguntas, o usuário apresenta atitudes e comportamentos na interação que se configuram como responsivose aparentemente passivos.

Em relação a isso, é nec essá rio estender a a nálise a lém dos limites a parentes e levantar a questão de que isso geralmente acontece porque o profissional de saúde é educado para ser o provedor ativo do cuidado e o usuário o receptor passivo. Segundo Trostle (1988), controlando a sinforma ções os profissiona is ga nham podere promovem a dependência e passividade do paciente.

Isso acontece também pelo fato de o usuário ter se acostumado a ter um papel passivo na interação, uma vez que pouca ou nenhuma oportunidade lhe é dada para se expressar e por não existir para ele nenhum meio de submeter à crítica as palavras do profissional de saúde.

No estudo de Rogers et al. (2000), por exemplo, alguns pacientes disseram que sentiam que os médicos geralmente não queriam dar a eles muita informação sobre sua doença ou tratamento. De modo semelhante, na pesquisa de Fontanella e Turato (2002) alguns pacientes revelaram que, ao atendê-los, os profissionais pareciam distantes, técnica ou pessoalmente.

Segundo Roter (2000), profissionais e pacientes estão sempre em posições tão desiguais que poucos destes últimos podem realmente exercer um papel na interação em igualdade de condições com os primeiros, adotando a passividade, 
sem estarem completamente cientes ou capazes de negociar uma posição mais ativa.

Outra razão pode ser o fato de que, a própria organização e funcionamento das instituições favorece a ilusão de onipotência e uso do poder pelos profissionais de saúde, deixando como única opção aos usuários, a submissão (MADONADO; CANEША, 2003).

É inegável a distância social e de formação que na maioria das vezes existe entre o usuário de serviço público e o profissional de saúde. Segundo Lupton (1997), pessoas com níveis educacionais mais baixos são de certa forma mais reverentes aos profissionais, freqüentemente pelo respeito que elas têm pelos seus anos de formação universitária e conhecimento acadêmico. Essa realidade caracteriza a interação entre o profissional e o usuário como distante e assimétrica a qual, de certa maneira, limita as capacidades do usuário em se colocar como sujeito ativo na relação.

A distância e a assimetria na interação entre o profissional e o usuário pode explicar a dificuldade que este último tem de entender as informações, se colocar na relação, fazer perguntas, tirar dúvidas e obter as explicações que deseja. Algumas situações chegam a fazê-los sentir-se incapacitados ou constrangidos diante do profissional de saúde, com medo de falar algo que contrarie o profissional e perder o direito ao tratamento. Haugli, Strand e Finset (2004), por exemplo, em sua pesquisa com pacientes portadores de doenças reumáticas, constataram que eles consideravam difícil obter informações dos profissionais. Não faziam perguntas porque tinham medo de perguntar alguma coisa que o profissional acharia irrelevante e também porque supunham que iriam tomar muito tempo do profissional [um usuário participante desta pesquisa me disse isso também]. Os autores concluíram que aqueles pacientes tinham um sentimento de estarem sozinhos com seus sintomas, de não serem acreditados e de não terem as informaçõesque precisavam.

O estudo de Rogers et al. (2000) aponta para uma outra razão que pode explicar esse comportamento passivo do usuário. Segundo os autores, os pacientes pesquisados por eles acreditavam que os médicos sabiam o que era melhor para eles, portanto, consideravam que não deviam fazer-lhes perguntas.

O Interacionismo Simbólico enfatiza que nós, seres humanos, definimos a situação em que nos encontramos em vez de simplesmente sermos responsivos a 
ela. Somos sempre dinâmicos e ativos em vez de estáticos e passivos (CHARON, 1998). Nesta pesquisa, foi possível perceber que, embora, na maioria das vezes, o usuário exerça um papel passivo na interação, isso não significa que ele "é" passivo (grifo nosso). À sua maneira, mostra que não concorda com tudo que o profissional de saúde lhe diz.

\footnotetext{
"Olha, eu tenho analisado muitas coisas que talvez não bate certo. Umas coisas que eles falam que muitas vezes eu não concordo. [...] Quase todas a gente concorda porque eles estudaram para isso, então eu acho que a gente é bem mais... Nunca que a gente vai saber tanto quanto eles, nunca. Eu não estudei a parte da medicina, então eu não vou saber. Então, quando ele fala, eu tenho que concordarcom o que ele fala. Agora, se é uma coisa que eu acho que... Uma coisa que não cabe para mim, então talvez eu discordo, mas a maioria das coisas eu concordo, sim." (C 21)
}

O que esse resultado aponta é para o fato de que o usuário, a seu modo, coloca-se na interação mostrando que está a tento aos elementos contidos nela. Como será visto mais adiante, da interação o usuário retira elementos significativos para depois agir.

\subsubsection{O manejo da hipertensão arterial}

O profissional de saúde considera que, teoricamente, por ser amplamente estudada no mundo todo e ter protocolos estabelecidos por órgãos e instituições oficiais, a HA é de manejo relativamente simples. Todavia, na prática, é de manejo complexo porcausa da interferência de alguns fatores relacionados ao serviço de saúde, ao SUS como as más condições de trabalho. Também por causa de fatores relacionadosao usuário como a dificuldade ou a falta de adesão ao RT.

\subsubsection{Más condições de trabalho}

As condições de trabalho do profissional de saúde caracterizadas pela grande demanda de usuários que, aliada ao número limitado de profissionais, gera sobrecarga de trabalho, a baixa remuneração e a sua reduzida disponibilidade de tempo, prejudicam a capacidade que o profissional tem de lidar efetivamente com a doença. 
Outras dificuldades ta mbém trazem limitações a o trabalho do profissional de saúde junto ao hipertenso, como a falta ou insuficiência de medicamentos disponíveis ao usuário, a morosidade dos serviços de apoio ou as dificuldades de acesso a exames e a consultas.

“Agora, fazer isso no serviço público de saúde é um desafio sem tamanho porque a gente sempre trabalha com a capacidade aquém da necessidade que a população tem. Então a gente tenta fazer seguimento, tenta fazer acompanhamento, mas o volume de pessoas precisando de atendimento é sempre maior que aquele que a gente dá conta de atender. Às vezes, você programa um seguimento e nos intervalos entre uma consulta e outra acontecem intercomências e você não consegue acompanhar o paciente nesses momentos porque, ou ele tem dificuldade de acesso ao serviço onde você está ou ele tem que procurar outro serviço, e você acaba não tendo condições de manejar essas situações às vezes de cuidado. [...] O duro é quando a gente não oferece aquilo que o sistema todo é obrigado a oferecer, isso é que às vezes... Você quer saber se ele tem comprometimento cardíaco, você precisa de um Rx de tórax, de um eletro, você não tem... Leva três, quatro meses para conseguir ter acesso a exames, a pessoa tem que ficar correndo, fazendo a via crucis dele, sem fim, para conseguir aquele exame." (P 12)

“E agora esses remédios, parece que não se está achando mais. Me parece que não está fomecendo mais. Quer dizer, só aí já é uma grande perda porque diminui a sua opção. Você fica com três, quatro medic amentos que às vezes não tem... Você fica muito restrito. Então, o uso da medicação, às vezes... O controle da pressão no serviço público é mais complicado por causa disso ta mbém." (P 10)

Inevitavelmente, quando as condições de trabalho do profissional de saúde não são boas, trazem implicações para a qualidade do atendimento a o hipertenso. De acordo com Maldonado e Canella (2003), a instituição dificulta sistematicamente a interação entre o profissional de saúde e o usuário por não oferecercondições mínimas para a rea lização de um bom atendimento. 


\subsubsection{Tipologia do usuánio}

Outro fatorapontado pelo profissional de saúde que prejudica o manejo da HA relaciona-se com o próprio usuário.

Para que se entenda em que sentido o usuário prejudica o manejo da HA pelo profissional de saúde, é necessário saber que ele lança mão de uma espécie de classificação dos usuários utilizando a adesão / não-adesão ao RT como referência.

Sob a ótica do profissional de saúde, o usuário está compreendido em dois grupos: o grupo dos usuá nios que a derem a o RTe o dos que não aderem.

O usuário que adere a o RT é aquele que o profissional considera que segue suas recomendações conforme ele determina.

“a gente vê que é um paciente que vai direitinho" (P 15).

“Ele toma sempre, ele está sempre com a pressão boa, [...] Eles passam a achar aquilo tão natural quanto escovar os dentes e não se queixam mais de que estão tomando medicação." ( P 8 )

O segundo grupo de usuários - aqueles que não aderem -, o profissional de saúde os divide em dois tipos, conforme as razões que acredita que eles têm para não aderir: Um tipo de usuário é aquele que, na sua perspectiva, não adere ao RT porque não quer. O outro tipo é aquele que não adere porque tem dificuldades.

“Olha, eu acho que tem dois perfis de pessoa. Tem aquela pessoa que é rebelde, tem aquela pessoa que não aceita, que não quer, que não faz e tem aquela pessoa que... ela não... ela faz o tratamento, mas ela não consegue alcançaraquele objetivo. Não porque ela não queira, porque ela seja rebelde, mas por outras circunstâncias, outras... às vezes ela não tem acesso a determinadas coisas que precisa para fazer o tratamento, o que dificulta. Então, tem as pessoas que não querem, que não aceitam e tem as pessoas que têm dificuldades, eu vejo assim." (P 13)

“Tem aqueles que são hipertensos e tomam a medicação e tem os que são hipertensos, mas não querem tomar a medicação com medo de ficar dependentesda medic ação". (P 25) 
Segundo os profissionais de saúde, as dificuldades do usuário são diversas como, problemas sociais [família], financeiros [pouca renda, desemprego], cultura is [crenças], pessoais e emocionais. Há também as dificuldades que o sistema de saúde lhe impõe, como as de acesso [a especialistas, exames, agendamento] e as de fomecimento de medicações. Há a inda as dificuldades próprias do RT como as mudanças de hábitose estilo de vida, a necessidade de controle, a dependência e as limita ções.

\footnotetext{
"Alguns nem têm condições de controlar porque trabalham, comem no trabalho, comem na rua, não têm alimentação adequada. [...] O marido está desempregado, começa a beber, começa a ter problema de relacionamento dentro de casa; quando começa a ver seus filhos de quinze, dezessete, vinte anos sendo presos, à mercê da droga, violência, isso é que às vezes compromete muito o sucesso do tratamento. [...] ...uma parcela, uma boa parcela da população que a gente atende, principalmente nas comunidades mais pobres, tem o problema do nível de instrução mesmo, uma boa parcela dos idosos não são alfabetizados, não conseguem gravar o nome dos medic amentos." (P 12)
}

Tais dificuldades são relatadas na interação pelo usuário ao profissional de saúde. Ele fala sobre os problemas que encontra para seguiro RT.

\footnotetext{
“A gente passa alguma coisa que a gente está sentindo, o que está acontecendo na vida da gente, porque, às vezes, é mais o estado emocional que está elevando a pressão." (C 11)
}

De modo geral, o profissional de saúde fica sensibilizado com a situação do usuário que tem dificuldades.

“... é difícil para eles também porque todo dia tem que tomar remédio." (P 14). 
“Então, é difícil para eles. Uma pessoa que vive com pouquíssimo dinheiro e [tem que] comprar remédio, é complic ado. [...] É difícil acreditar, é difícil ter fé num tratamento prescrito dessa forma. Uma doença que você não sente quase nada, veja bem, não é fácil de ficar... 'Puxa, eu vou tomar um remédio que às vezes me dá tontura ou me faz uninar dema is, porque aquele médico que nem conversou comigo, mandou'." (P 8)

"Aquele paciente que não sente nada e que não toma remédio. E não é só tomar um remédio, são dois, três, quatro, cinco, dez comprimidos ao dia, sem estar sentindo nada. É ele ter que emagrecer sem ter condições de mudar a sua dieta, é ele ter que parar de fumare já fumar há vinte e tantos anos. Então, é difíc il, é extremamente difícil."(P 26)

"Coitado do paciente, às vezes não tem nem emprego e como que ele vai se alimentar direito, como que ele vai seguir uma dieta que a gente vai passar para ele. [...] Nesta região, o próprio cuiabano em si, a dieta dele é muito rica em gordura, ele gosta de farofa de banana, ele gosta de sarapatel, peixe frito. Então, a dieta em si, a dificuldade dele é mais essa. A dificuldade de diminuir o sal da alimentação, de diminuir a gordura e também do próprio exercício físic o...". (P 15)

Alguns profissiona is chegam a imaginar-se na situação do usuário e perceber que para elestambém seria muito difícil estarna posição dele.

"Olha, no meu caso, acho que no começo eu ta mbém ia fic ar assustada. Eu ia ficar assustada porque estou acostumada a levar uma vida assim de comer tudo, fazer caminhada, andar bastante, ter uma vida agitada. Aí, de repente eu vou ter uma vida assim, mais controlada. Acho que no começo eu também não aceitaria não." (P 6)

"Falar é muito fácil, não é. A gente falarque ele precisa tomar é muito fácil. Agora, daí para ele encontrar essa medicação, eu sei que é complicado. (...) É complicado porque é uma mudança realmente no estilo de vida dele..." (P 27)

Mas essa visão da situação do usuário não é compartilhada por alguns dos profissionais pesquisados que não a vêem como difícil, embora saibam das dific ulda des dos usuá rios porque eles lhes relatam. 


\begin{abstract}
“Não, eu acho assim... Eu não vejo dificuldade, eu não vejo dificuldade. Eu vejo que eles encaram a doença numa boa, tranqüilos. Então, eu não acho que eles tenham problemas. A minha opinião, assim, eu vejo que eles levam a vida nomalmente. Eles fazem o tratamento e encaram como se não tivessem problema porque eles seguem corretamente, então eu não vejo que eles tenham problema não." (P 13)
\end{abstract}

Como se vê, a lém da própria adesão, as razões ou motivos de não-adesão, portanto, parecem ser um elemento signific ativo na interação do profissional de saúde com o usuánio.

De fato, o problema da não-adesão ao RT tem sido amplamente estudado e várias razões para os clientes não aderirem têm sido apontadas (KOCHAR; WOODS, 1990; SMELT无; BARE, 1994; CARPENITO, 1997; LESSA, 1998; G ONÇALVES et al., 1999; PIERIN, 2001; DIREIRIZIS BRASILEIRAS DE HIPERTENSÃO ARTERIAL (IV), 2002; CASTRO; TIEIZMANN; SCHO FFEL, 2003; PAVLOVICH-DANIS, 2003). Há alguns estudos, inclusive, que investigaram a perspectiva que os profissionais de saúde tinham sobre as razões dos pacientes para nã o aderirem ao RT.

Um deles foi a pesquisa de McGrath (1999) na qual um de seus propósitos foi saber a ótica dos médicos sobre as razões para a não-adesão de seus pacientes à prescrição medicamentosa. Diferentemente dos resultados encontrados nesta pesquisa, na opinião dos profissionais, os pacientes não aderiam às suas recomendações porque simplesmente esqueciam de tomar as medicações, porque se sentiam melhores e porque passavam a ter efeitos colaterais ou pensavam que os teriam.

Num outro estudo, Fineman (1991) desc obriu que, assim como os profissionais de saúde participantes desta pesquisa, os sujeitos da sua investigação utilizavam-se de uma tipologia para identificar o paciente. Eles o classificavam como não aderente, conforme as razões que acreditavam que eles tinham para não aderir. Desta forma, os pacientes foram classificados em dois grupos: os incapazes de aderir porque tinham alguma dificuldade física cognitiva ou mental e os que simplesmente não estavam dispostos a aderir. 


\subsubsection{A percepção do problema}

No manejo da HA, portanto, o profissional de saúde depara-se com doistipos de usuários - os que aderem ao RT e os que não aderem. O problema é que, na realidade, o profissional percebe que a maioria está compreendida no grupo daquelesque não aderem.

\footnotetext{
"Agora, desafortunadamente a gente tem que reconhecer o grau de insucesso é... [alto] [...] Olha, eu acho até que é a maioria. A maioria tenta, mas não dá certo." (P 18)

“Então, a maioria que chega aqui, não toma o remédio direito, na hora certa, a alimentação come de tudo..." (P 7)
}

Com efeito, o fenômeno da não-adesão é muito comum, e é comprovado cientificamente. Segundo Kra silcic (2001), há estudos, ma is freqüentes no exterior do que no Brasil, que demonstram a dificuldade prática de se atingir os resultados da adesão, mesmo em países desenvolvidos e com sistemas de saúde mais bem estruturados.

A não-adesão do usuário ao RT é percebida pelo profissional de saúde a partir da declaração do primeiro que, geralmente na interação, costuma falar de suas dificuldades para seguir o RT, seja pela falta de medicação ou de dinheiro para comprá-la, pelos efeitos colaterais que ela provoca, pelo medo de ficar dependente da medicação, pela dificuldade de se adaptarà dieta hipossódica ou para emagrecerou pararde fumar, entre outros.

\footnotetext{
“Ele fala - 'Se eu estou com a pressão alta, vou fic ar o resto da vida, então para quê eu vou tomar medic ação? Não precisa tomar, então. É uma coisa que não está valendo nada' ". (P 6)

“O que o paciente diz? - 'Ah, doutor, é difícil a gente seguir dieta porque tem muita gente na casa e aí para fazer comida sem sal eu tenho que fazer separado para mim, meus filhos, meus netos não comem sem sal. Aí eu não faço para mim e já como com o pessoal todo'. - 'Tem coisas que não dá para evitar, os problemas da vida a gente não consegue resolver, meu marido está desempregado, tem conta para pagar, não tem dinheiro'. - 'O remédio às vezes fazmal, eu tomo o diurétic o e unino dema is e a quilo acaba comigo e eu passo o dia todo fraca. Me dá uma dor de cabeça, uma
} 
tontura, e aí eu diminuo a dose ou às vezes eu vou lá na famácia, no posto medir e a pressão está boa e aí eu diminuo'. - 'Eu não consigo achar o remédio que você me passa'." (P 12)

De outro modo, o profissional também constata a não-adesão do usuá rio ao RT na sua prática, de forma empírica, fazendo um levantamento subjetivo [observação e intuição] da disposição e habilidade do usuário para aderir.

\begin{abstract}
“O básico da gente é perguntar para ele. Na primeira consulta eu sempre digo para ele que o que eu sei dentro da hipertensão é que quem é hipertenso, toma as medicações e sabe o nome das medicações. Então, na primeira consulta a gente deixa isso bem claro e que a gente está sabendo quando eles tomam e quando não tomam a medic ação. Então, no retomo você pergunta para ele - 'O que você está tomando?' E ele começa - 'Ah! Aquele comprimidinho, tal...' Aí você sabe que... [ele não está tomando]" (P
\end{abstract} 27)

“Bom, a primeira visão que a gente tem é o aparecimento de complicações que você não esperava. Eu já tive doente que claramente fazia isso: só na hora que vinha ao médico é que começava a se cuidar. Uma semana antes da consulta marcada, ele começava... Voltava a tomar seu remédio com regularidade e quando chegava aqui estava tudo nos trinques. Só que você ia ver, a hipertrofia ventricular estava aumentada. A desabilidade para a prova de esforço tinha aumentado, a cegueira dele avançou..." (P 18)

Observação, percepção e a declaração do usuário são ferramentas importantes, mas não suficientes, para quem quer avaliar a adesão do usuário ao RT. O ideal é que elas sejam complementadas, de tempos em tempos, com pesquisas que abordem com mais minúcias essa questão, pois a té cientificamente a não-a desão é a lgo difícil de se detectar ou estabelecer.

Percebida a não-adesão, para o profissional de saúde ela passa a ser um problema que precisa ser resolvido. Neste sentido, ele lança mão de uma estratégia para administrá-lo - a conscientiza ção.

De acordo com Blummer (1969), na perspectiva do Interacionismo Simbólico, ao invés de semos um organismo que meramente responde a um conjunto de fatores ou por meio deles, somos um organismo ativo que lida com o mundo à sua 
volta, com tudo que interage com ele; que constrói uma linha de ação com base no que consideramos importante, signific a tivo.

Por meio de um processo de auto-indic ação no qual um ou ma is objetos são notados por nós [outras pessoas, nosso self, coisas, ações passadas, idéias, símbolos, instituições e assim por diante], atribuímos significado a eles e usamos esses signific ados como base para dirigir nossas ações.

Segundo Charon (1998), nossas ações existem em situações que definimos por meio de dois processos simultâneos e contínuos - um aberto, que decorre da interação que temos com outras pessoas, e outro fechado, decorrente da interação que temos conosco. Construímos, então, nosso plano de ação tendo em conta todos esses elementos. Nossas decisões, portanto, são motivadas pela definição que temos da situação a té aquele ponto, nossas metas, planos, objetos sociais, conseqüências futuras, memórias, entre outros.

\subsection{Razões para conscientizar}

O contexto da interação entre o profissional de saúde e o usuário representado pelas categorias até agora discutidas, se configura com elementos diversos que influenciam a decisão do profissional de conscientizar o usuário da sua necessidade de aderir a o RT.

Da mesma forma, algumas das concepções apreendidas nos relatos dos profissiona is participantes, constituem-se, sob o ponto de vista da pesquisadora, em razões que levam o profissional a agir dessa maneira a fim de promover a adesão do usuário a o RT.

São essas razões serão descritas a seguir, antes de apresentamos como o profissional de saúde concebe e realiza a conscientização do usuário.

\subsubsection{A concepção de regime terapêutico}

Para o profissional de saúde, o RTé a prescrição de um conjunto de medidas terapêuticas que ele designa ao usuário com o objetivo de controlar a HA. Alguns profissionais deixaram transparecer que, para eles, o RT não significa apenas prescrever medicamentos, mas intervirna vida do usuário. 
“Não é dar remédio para ele. Dar remédio, até o farmacêutico está dando. É interferir na vida." (P 18)

“...são vários outros aspec tos que você tem que tentar interferir e que não é fácil de você modificar, como por exemplo, reduzir peso, como por exemplo, pararde fumar..." (P 26)

Tal concepção sugere que o profissional de saúde confere a si poder sobre a vida do usuário. Isso não surpreende, pois como foi visto até agora, tanto ele se coloca na interação como a pessoa central, quanto o usuário, de uma certa forma, sustenta essa centralidade.

Essa acepção tem como fundamento o tradicional e mais comum modelo de interação - o modelo centrado no médico [ou no profissional] - que é caracterizado por uma relação autoritária entre o profissional e o paciente, na qual o primeiro incorpora o papel de expert e o último desenvolve um papel passivo (DE VALK et al., 2001). Nessa concepção, o usuário é o indivíduo que não sabe nada e o profissional é aquele que fala para ele como viver, como comer, o que pode e o que não pode fazer.

Para a maionia dos profissionais pesquisados, o RT não é tido como uma ordem porque pensa que não obriga o usuário a segui-lo, mas sim como um conselho dirigido a ele.

“Eu acho que são conselhos. Você não pode obrigar ninguém a nada. É um direito do paciente não querer tratar,..." (P 28)

Na concepção do profissional, o RT - tanto as medidas farmacológicas quanto as não farmacológicas - é o recurso terapêutico que ele tem em mãos, alicerçado no sabercientífico, que representa o que há de melhor para o usuário.

“E eu tenho que passar as orientações daquilo que eu considero, baseado na literatura hoje, a gente considera que é o melhorpara o paciente." (P 26)

Nesta concepção é possível perceber que o profissional de saúde, legitimado pela sua formação pautada no modelo biomédico, e pelo que as organizações e documentos científicos determinam, crê que sabe sobre o 
problema de saúde do usuário, sabe como solucioná-lo ou controlá-lo e sabe o que é melhor para o hipertenso.

Benlinguer (1993) diz que quando o profissional prescreve o que o cliente deve fazer e como deve se comportar, argumentando que tudo isso é para o bem dele, não the dando o benefício da escolha, surgem problemas de ética e liberdade.

\subsubsection{A concepção sobre a adesão ao regime terapêutico}

Como já foi visto, para o profissional de saúde, a adesão do usuário ao RTé uma questão central. Isto é percebido no seu interesse em ter atitudes e comportamentos para o usuário confiar, acreditar nele e aderir. Da mesma forma, é percebido nas suas ações que demonstram preocupação com o seguimento do usuário às suas recomendações.

A gênese dessa preocupação reside no fato de que esse é um tema comumente reforçado nas constantes informações recebidas na sua formação, em eventos, na literatura e também nas observações feitas na sua prática de atenção ao hipertenso: a adesão ao RT é condição fundamental para o controle da PA e a regressão de lesões degenerativas nos chamadosórgãos-a lvo (KRASILCIC, 2001).

Para o profissional de saúde, é muito importante que ocorra a adesão do usuário a o RT, porque dela depende o sucesso do tratamento, e esse representa o resultado do seu trabalho que só é visto concretamente no usuário, no seu corpo, por meio do controle da PA e ausência de complicações. Da a desão do usuário ao RT depende o sucesso ou o fracasso do seu trabalho.

Sua preocupação, portanto, é ver esse resultado alcançado. Mas tal resultado só será passível de ser atingido se o usuário aderir. Neste sentido, é indispensável que ocorra a a desão do usuário ao RT.

Outra visão que o profissional tem da adesão é a de que, quando ela acontece de forma positiva, ou seja, quando o usuário adere ao RT, o resultado alcançado ocorreu por mérito seu, não do usuário ou dos dois.

\footnotetext{
“...quando o cliente sai daqui com uma pressão controla da, com adesão a o tratamento, quer dizer, você fica mais tranqüila porque seu trabalho está sendo eficiente." (P 28)
} 
"A satisfação da gente é resolver e como a gente tem muita dificuldade para resolver quando a gente consegue resolver, é bom demais..." (P 12)

Em contraste, como será visto no final desta exposição, quando o resultado é negativo, ou seja, quando o usuário não adere ao RT, o mérito pelo insucesso é muito mais do usuário do que dele.

É inegável que a adesão ao RT seja essencial para o controle da HA e redução de complicações. Entretanto, é bom destacar que ela não é mais importante que o usuário - o sujeito que a realiza. Do exposto a té agora, é possível inferir que essa não é a visão do profissional de saúde participante desta pesquisa.

E mais, novamente é possível perceber que o profissional de saúde confere a si um grande poder, em detrimento do que é conferido ao usuário.

\subsubsection{Responsabilidade com a adesão ao regime terapêutico}

Os profissionais de saúde são unânimes em considerar que a responsabilidade pela adesão a o RTé de todos - deles, do serviço de saúde e do SUS, do usuário e de sua família. Embora eles pensem que o compromisso com a adesão ao RT seja de todos, sua concepção é a de que cada um - pessoa ou instituição - responde por sua responsabilidade separadamente. Há um limite no compromisso de cada um.

\footnotetext{
"Tem coisas que são responsabilidades minhas como médico, outras são responsabilidades do sistema de saúde como um todo, que vai além da minha ação; outras têm a ver com os hábitos que o próprio paciente pode modific ar, pode contribuir. E há outros relacionados à condição de vida dele que estão a lém da capacidade da gente resolver." (P 12)
}

Neste sentido, a maioria dos profissiona is de saúde acredita que cabe a eles apenas a responsabilidade de desenvolver as tarefas já pré-definidas nos protocolos dos consensos e programas, além de atender bem o usuário, estabelecendo com ele relação de confiança, passando credibilidade, criando um vínculo, sendo ético, não tendo uma postura de superioridade, não sendo distante, estimulando o usuário a fazer o RTe conscientizando-o da necessidade de aderir. 
“Então, primeiro, cabe ao profissional tomar consciência do que ele está passando para o paciente, a sorientações direitinho para ele..." (P 15)

"Eu faço o acompanhamento e dou a medicação." (P 25)

“...mas isso não nos ausenta, enquanto profissionais de saúde, de estar acompanhando, de estar incentivando ele a fazer o tratamento e estar seguindo." (P 13)

Para o profissional, a responsabilidade dos serviços de saúde é de proporcionar boas condições de trabalho aos profissionais, dar um bom atendimento aos usuários, inclusive reforçando as informações que lhes são dadas, fazer buscas dos faltosos, dentre outras. Ao SUS cabe, dentre muitas tarefas, melhorar a sua organização, reduzir a demanda de usuários por profissional e fomecer os medic amentos ao usuário.

\footnotetext{
"Do médico, dos auxiliares, dos enfermeiros, da diretoria para poder estar organizando a farmácia, ter toda a medicação. Depende também lá de cima, depende do secretário estar mandando toda a medicação porque não adianta você ter um programa..." (P 6)
}

Mas, segundo os profissionais pesquisados, a responsabilidade maior pela adesão ao RT é do usuário. Cabe a ele assimilar as informações que lhe são passadas, ter vontade de seguir o RTe, de fato, aderir. É ele quem deve arcarcom a maior parte da responsabilidade, pois o profissional, o senviço de saúde e o SUS já fazem a sua parte. À família do usuário cabe a responsabilidade de acompanhá-lo e dar suporte.

“Então, eu... lógico, por mais que ele sinta-se como meu parceiro, a responsabilida de dele é maior que a minha." (P 25)

“Então, a gente nunca fala isoladamente, a gente sempre fala da importância da nutrição, da importância do médico, da importância da gente e da importância dele também porque ele é o principal. Se ele fizera parte dele, aí nósjá ganhamoso jogo." (P 27)

"Aí eu acho que a responsabilidade é mais dele porque todo o suporte que a gente podia dar, a gente já está dando para ele. Aí, vai dele seguir, querer 
seguir ou não. [...] Eu acho que tem que partir dele mesmo, ele que tem que querer se doar para aquele tratamento, querer melhorar. [...] ... mas também tem um limite. Chega uma hora que a gente já fez tudo que podia fazer, já conversou com a família, já foi atrás do paciente, já conversou com o paciente e não teve jeito. Então, aí, nesse caso, eu acho que o serviço de saúde mesmo já fez a sua parte. Aí vai depender do paciente e dos seus fa milia res." (P 13)

Analisando a perspectiva dos profissiona is de saúde sobre a responsabilidade com a adesão ao RT, a consideração de que ela deva ser dividida entre todos guarda em seu ceme a concepção de um trabalho organizado nos moldes do paradigma biomédico, o qual se estrutura em tomo do trabalho do médico, voltado para o atendimento clínico e com práticas dos profissionais de saúde distintas, isoladas, apenas complementares e às vezes concorrentes. Além disso, os usuários são vistos como recipientes do trabalho dos profissionais e o serviço de saúde como mero facilitador dessa organização.

Neste contexto, a adesão ao RT é vista como finalidade do trabalho de todos, mas de forma diluída e compartimentalizada, distante da idéia de responsabilidade compartilhada e envolvimento conjunto. Isto não causa surpresa, pois como afimam Hammond, Bandak e Williams (1999), médic os e enfemeiras e outros membros de equipes multidisciplinares têm sido educados e socializados exclusivamente dentro do próprio domínio de suas profissões com pouca experiência de responsabilidades compartilhadas.

O resultado disso é que cada profissional define para si qual é a sua responsabilidade na adesão, definindo também a do usuário que é deixado à sua própria sorte com sua parte na "responsabilidade de todos" (grifo nosso), como, de fato, um profissional de saúde participante desta pesquisa reconhece.

"Eu acho que são várias responsabilidades que se diluem, um fica jogando para o outro e no fim o paciente acaba desamparado." (P 8)

\subsubsection{Usuário que não adere - paciente de risco}

O profissional de saúde atribui ao usuário que não adere a caractenística de ser um paciente de risco. Isto parece acontecer por causa do conhecimento e 
experiência que o profissional de saúde tem sobre a $H A$, adquiridos na sua formação teórica e prática, a lém de suas vivências pessoa is ou com familiares. Ele sabe o que significa ser portador dessa doença e das conseqüências que podem advir sobre a vida do usuário, se ele não aderir a o RT.

“Para mim ele é um paciente de risco, eu acho que ele é um paciente que requer cuidados" . (P 7)

"Ah! Eu vejo assim... Ele está caminhando para a morte. Eu vejo porque a maior parte é isso, né. Você caminha para a morte." (P 19)

Esse fato parece incomodá-lo, pois pensa que, mesmo que o usuário já tenha sido informado disso, não acredita na gravidade da HA e que corre o risco de complicare até morrer.

"Olha, eu acho assim que eles não acreditam, eles não têm a noção da gravidade que é a hipertensão." (P 7)

“Tem paciente que não ac eita, tem paciente que você está falando com ele e ele acha que aquilo ali não é verdade, que aquilo ali é de mentira,..." (P 6)

“Eu acho assim. A pessoa que não adere ao tratamento não tem noção do nisco que come, não tem..." (P28)

Neste sentido, no seu entender, é preciso que seja dada maior ênfase nesse ponto, a fim de que o usuário esteja mais consciente dos seus riscos e, conseqüentemente, resolva aderir.

Como já foi visto, o profissional de saúde considera que um dos fatores fundamentais para uma boa interação entre ele e o usuário é a confiança e a credibilidade, mais especificamente, é a necessidade de que o usuário confie e acredite nele, nas coisas que ele lhe diz, para poder aderir, pois ele sabe o que é melhor para o usuário, sabe o que ele tem que fazere como deve proceder.

No entendimento do profissional, portanto, a ele cabe a tarefa de fazercom que o usuário acredite que corre perigo de morte e/ou de complicar, para que possa a derir. Cabe a ele "fomecer" o conhecimento a o usuá rio "fazendo" com que 
ele saiba o que pode lhe acontecer quando não a dere a o RT, ou seja, compete-lhe o papel de conscientizá-lo (grifos nosso).

"Na realidade, eu tento esclarecer, para que a pessoa adira e que ela tenha um certo grau de conhecimento dentro das limitações." (P 18)

Para o profissional de saúde, enquanto o usuário não estiver consciente dos niscosque corre, ele não vai se convencer da necessidade de adesão ao RT.

“Eu acho assim, a pessoa enquanto não consegue enxergar os riscos, ela não vê a necessidade de tratamento. Então, por exemplo: 'Por quê eu vou tratara hipertensão se ela não vai me levara nada?'" (P 28)

Somente quando o usuário tiver consciência dos riscos, confiando no profissional de saúde, acreditando nele, é que vai aderir.

“Acho que o fato de o paciente ter consciência, se ele tem consciência da sua doença e tem a confiança no seu médico, ele vai tomar o remédio de forma adequada." (P 26)

Douglas apud Martin (2000), a firma que o modelo de percepção do risco que sempre chega à conclusão de que deveria haver mais educação para o público desinformado, sugerindo que as pessoas se amiscam por não saberem dos perigos, é inocente. Segundo a autora, é improvável que mais informação garanta diferenças de opinião sobre riscos. Isso porque é preciso levar em conta que "as pessoas fazem parte de um contexto cultural em que suas escolhas fazem sentido ou não de acordo com o que é valorizado socia Imente" (MARTIN, 2000, 102).

O Interacionismo Simbólico se sustenta em três premissas: Primeiro, a de que os seres humanos agem em direção às coisas com base nos significados que essas coisas têm para eles. Segundo, que o significado de tais coisas tem origem ou surgem da interação social que alguém tem com outras pessoas; e, terceiro, que esses significados são manipulados e modificados por meio de um processo interpretativo usado pela pessoa para lidar com as situações que ela encontra (BLUMMER, 1969). 
Segundo Blummer (1969), toda interação só é simbólic a quando envolve esse processo interpretativo. Quando reagimos de forma reflexiva ou respondemos imediatamente a uma ação sem pensar, nossa interação não é simbólica. Mas, a partir do momento que buscamos significado nas nossas ações e/ou na das outras pessoas, então, estamos tendo uma interação simbólica.

Pela explanação feita até agora, é possível perceber que o profissional de saúde e o usuário interagem simbolicamente, pois a preendem os sentidos que os diversos e diferentes elementos na interação têm para eles - as pessoas, as instituições, a HA, o RT, entre outros.

Dessa interação, da interpretação, é que surge para o profissional de saúde a necessidade de conscientizar o usuário de que ele precisa aderir a o RTpara evitar as complic ações.

Do conjunto das ações que são desenvolvidas pelo profissional de saúde na interação com o usuário, a mais relevante é a conscientização. Como ela é concebida e realizada será descrito a seguir.

\subsection{Conscientização}

Os relatos dos profissiona is rea lçam a importância que eles tendem a colocar sobre essa ação, mesmo considerando que ela não é uma tarefa fácil.

\subsubsection{Tarefa difícil}

Na realidade, a dificulda de em conscientizar o usuário de que seu problema de saúde é sério, que acarreta danos à sua vida e de que a sua adesão ao RT é necessária para o controle da HA e para a redução dos riscos, é que constitui, para o profissional de saúde, o problema ma is difícil no manejo da HA.

\footnotetext{
“Então, a maior dificuldade que a gente encontra hoje é conscientizar a pessoa do que é a patologia e a necessidade de um tratamento continuado..." (P 18)

“...eu acho que o trabalho é árduo, penoso para que você possa conscientizá-lo da necessidade de tomar essa medicação." (P 26)
} 
Difícil porque o profissional de saúde considera que as suas condições de trabalho não facilitam e, ainda, porque o usuário tem muitas dificuldades, principalmente as que estão no âmbito do social, que prejudicam a sua adesão ao RT, fato que, para o profissional, é trabalhoso de lidar.

\footnotetext{
"O que dá trabalho para a gente é que você não tem como interferir no meio [social] do doente." (P 18)

“...as condições socioeconômicas do paciente ou do próprio país que muitas vezes... como eu disse antes, ele não tem nem o que comer, então como que a gente vai orientá-lo em relação à dieta se ele come só a rroz, feijão e farinha, se tiver." (P 15)
}

Esse resulta do não supreende, pois historicamente os profissiona is médicos e de enfermagem foram formados com base no modelo biomédico cujo foco se direciona para a doença e não para a pessoa. Conseqüentemente, toda demanda que vem do usuário que não se configura no seu corpo ou que não se traduz em sina is e sintomas, toma-se difíc il para o profissional lidar.

Isso foi evidenciado também por Caprara e Rodrigues (2004) em pesquisa com profissionais médicos do Programa de Saúde da Família e sua relação com o usuário. De acordo com as autoras, em relação aos aspectos psicossociais, na maioria das consultas (91,4\%) os médicos não exploravam os medos e ansiedades dos usuários. Na opinião das a utoras, muitas vezes os pacientes fazem referências a a spectos soc iofamilia res, seus medose ansiedades na sua condição de saúde, mas a maioria dos médicos escuta e até reconhece a pertinência da questão apresentada, masnão a explora com o paciente, da mesma forma e profundidade como faz com relação a os sintomas e sinais da doença.

Hellström et al. (1998) também descobriram, ao investigar a estrutura de significado que médicos tinham ao lidar com portadores de fibromialgia, que as visões dos profissiona is eram guia das pelo conhecimento biomédico e os problemas psic ossocia is a presenta dos pelos pacientes pareciam ser percebid os como sina is ou disfunções que só poderiam ser resolvidos pela aplicação de teorias científicasnaturais. A possibilidade de dialogar com o paciente, considerando-o como pessoa era relegada a segundo plano. 


\subsubsection{A concepção}

A conscientização tem um grande valor educativo e, neste sentido, é louvável que o profissional de saúde preocupe-se em desenvolvê-la. Entretanto, convém que se analise alguns aspectos que residem na forma como ela é concebida e realizada pelosparticipantes desta pesquisa.

O profissional de saúde concebe a conscientização como uma atividade educativa.

\footnotetext{
“basicamente isso, educação em saúde, conscientizar de que o melhor para ele é aderir ao tratamento..." (P 28).
}

Juntamente com ela, algumas palestras e trabalhos com grupos de hipertensos [esporádicos e isolados] também são considerados atividades de educação em saúde que têm o propósito de fazer com que o usuário tome consciência do seu problema.

As expressões "tentar meter na cabeça" do usuário, "colocar na cabecinha do paciente" e "fazer a cabeça dele", freqüentemente utilizadas pelos profissionais de saúde quando questionados sobre a ação de conscientizar, expressam, de forma clara, que a a cepção que o profissional de saúde tem sobre conscientização é pautada na concepção bancária da educação, descrita por Freire (1987), a qual vê os educandos como recipientes a serem enchidos pelo educador.

Segundo o autor, "nela, o educador aparece como seu indiscutível agente, como seu real sujeito, cuja tarefa indeclinável é 'encher' [grifo do autor] os educandos dos conteúdos de sua narração" (FREIRE, 1987, p. 57). Uma concepção segundo a qual as pessoas que ensinam acreditam que “o 'saber' é uma doação dos que se julgam sábios aos que julgam nada saber" (FREIRE, 1987, p. 58, grifo do autor).

\footnotetext{
"Aquele paciente que tem um tratamento iregular, ele tem muito mais manifestação da doença crônica do que aquele paciente que trata corretamente. São mais explícitas as conseqüências da doença, então, você acaba sabendo que com esse você tem que tentar meter na cabeça dele que ele tem que darvalor para a doença dele porque senão ele vai morrer daqui lá. Ele vai complicar com o tempo, médio prazo, já está com sinais da doença e que se ele não der valor naquele tratamento, não seguir
} 
as orientações, ele vai ter complic ações sérias e vai ter uma, digamos assim, uma expectativa de vida muito menor." (P 10)

“Faço a cabeça dele. [...] Então, você tem que a presentar a ele altemativas e argumentos, para que a pessoa realmente veja a importância do que ele está fazendo, tá entendendo?" (P 18)

“...colocarna cabecinha do paciente as orientações que para mim é o mais importante." (P 15)

Esse resultado é congruente com os achados de Wendhausen e Saupe (2003) que investigaram as concepções de educação em saúde de enfermeiros, auxiliares de enfermagem, médicos e cirurgiões-dentistas. As a utoras descobriram que, de modo geral, esses profissionais de saúde revelaram um modo tradicional de perceber a educação em saúde na qual as palavras passar, repassar e a expressão transmitir conhecimento eram recorrentes.

O poder garantido ao profissional de saúde por causa de sua formação científica faz com que ele se coloque em uma posição superior à do usuário, como detentor do conhecimento sobre o diagnóstico do problema, o prognóstico e sua resolução, e pense que tem o monopólio do conhecimento e manejo da $H A$, podendo mudar a forma do usuário pensare agir para o modo como ele pensa e age [ou agina]. O profissional, sob a égide da ciência, acredita que pode ter controle sobre o como, a saúde, a vida e a morte do usuário. Este, por sua vez, é aquele que não sabe nada sobre isso e que, portanto deve acreditar no profissional e aceitar o que ele lhe diz.

Gropper (1998), a fimma que os profissionais de saúde trazem para o encontro com o paciente suas próprias suposições, algumas das qua is têm sido intemaliza das durante seu processo de forma ção. Eles presumem que o conhecimento profissional seja superior ao conhecimento que os não profissiona is têm.

Ao assumir essa postura, o profissional de saúde pensa que cabe a ele a tarefa de dar, entregar, levar e transmitir o conhecimento ao usuário acreditando que isso é suficiente para induzir mudança de comportamento, bastando apenas depositá-lo na cabeça do usuário. Isso é um engano, pois segundo Benlinguer (1993), o comportamento não é mutável com um relacionamento pedagógico puro ou com conselhos pessoais. Ao contrário, é o resultado de condicionamentos 
psicológicos e relacionamentos reais no trabalho, na residência, no lazer, entre outros.

Nessa concepção, os múltiplos fatores que tomam a questão da adesão / não-adesão tão complexa deixam de ser examinados convenientemente, e de ser considerado que o conhecimento, apesar de ser uma condição necessária, não é suficiente "se não existir sintonia de culturas e propósitos entre informantes e informados, e se faltar o sentido do limite do 'sei que não sei' socrático [grifo do a utor] e do respeito a os direitos a lheios" (BERLINGUER, 1993, p. 152).

Nessa acepção, os conteúdos “depositados" (grifo nosso), "são retalhos da realidade desconectados da totalidade em que se engendram" (FREIRE, 1987, p. 57). São apenas infomações sobre a HA e o RT cuja ligação com o usuário e com sua vida reside somente no fato de que é ele quem tem a doença e é ele que tem a maior responsabilidade para aderir. No mais, o usuário e suas dificuldades e limitações para aderir são desconsiderados. Como sujeito da adesão, como centro da atenção, ele é negligenciado.

Neste sentido, o usuário não é visto como uma pessoa com potencial de troca de idéias e experiências. Nem como um sujeito com direito de fazer escolhas livres e com autonomia para manejar o seu problema de saúde e o RT. O profissional de saúde não o considera como membro ativo no seu processo de cuidado à saúde, como um adulto capaz de estabelecer, de forma amadurecida, uma aliança com ele para, juntos, conseguirem progressos no processo tera pêtico.

Contrariamente a essa concepção autoritária e reducionista do usuário existe a concepção de Rogers (1997) que tem na sua base humanista a crença de que toda pessoa tem uma percepção positiva sobre si mesma. O autor acredita que todo indivíduo está sempre buscando o equilíbrio e que ninguém o conhece melhor do que ele mesmo. Acredita também que o profissional seja um facilitador no processo de solução dos problemas da pessoa oferecendo-lhe elementos para que ele próprio decida qual o melhor caminho a seguir.

Para o profissional de saúde, conscientizar é falar ao usuário que a HA é grave, incurável e que acarreta complic ações e morte. É falar sobre a importância do RT e de seu seguimento como meio de controlar a doença e evitar as complicações. Mas é, principalmente, enfatizar para o usuário os riscos que ele corre pornão aderir ao RT. 


\begin{abstract}
"Seria falando sobre o que poderia levar se a pressão não estiver controlada. Explic ando as complicações que podem acontecer, por exemplo, quem tem pressão muito alta, é alguma coisa de um órgão que não está indo bem. Às vezes pode ser o rim, o coração mesmo que poderia ter um infarto ou, então, um derrame. Uma dessas complicações a que ele poderia estar sujeito." (P 16)
\end{abstract}

“A conscientização é exatamente o paciente saber que ele pode ter um derrame, é aquele paciente... é aquele exemplo do vizinho de alguém que teve uma morte súbita, daquele paciente que tem 42 anos que de repente ficou paralítico, fica na cama e não levanta mais, é aquele paciente que é renal crônico e que é submetido à diálise..." (P 26)

O profissional de saúde dá ênfase a os riscos de complicações da HA porque, para ele, é óbvia a sua ocorência, pois há comprovação científica de que elas podem ocorrer. O que ele diz ao usuário, então, pode acontecer.

“Porque para nósé tão óbvio, não é? Se ele não cuidar da hipertensão, são os órgãos vitais dele que estão em risco. Então a gente focaliza bem que é o rim que detona, que são as artérias dele que... a gente explic a assim." (P 27)

E também porque ele julga que é preciso algo muito forte para persuadir o usuário a acreditar no que ele lhe diz e assim aderir ao RT. Defic iência e morte são os argumentos encontrados por ele para dissuadir o usuário da idéia de não aderir e convencê-lo a aderir.

Além disso, ao enfatizar os riscos está, de certa forma, eximindo-se de sua responsabilidade sobre o que pode acontecer ao usuário pornão adenir ao RT.

Essa forma de convencimento tem valor relativo e duvidoso, pois o seu sucesso depende, entre outras coisas, do usuário e sua percepção de risco que inclui suas vivências, concepções e expectativas e que nem sempre é igual à do profissional. Além disso, deve-se considerar que na palavra risco está embutido um sentido negativo que elimina a idéia inversa de chance e oportunidade que poderia ser transmitida ao usuário. A ele poderia ser dito, por exemplo, que cuidando de si ele terá mais chances e oportunidades de melhorar sua saúde e qua lidade de vida.

A opção por esse enfoque não ajuda na comunicação com o usuário que, por sinal, guarda nela um grande problema - as formas de comunic ação. 


\subsubsection{Fomas de comunic ação}

Várias formas de comunicação são utilizadas pelo profissional de saúde na conscientização. Elas variam desde a brincadeira até a ameaça. Alguns chamam a atenção do usuário, dão lições de moral, "puxam a orelha", assustam, dramatizam ou apelam para o emocional, com a retórica de que está fazendo isso para o bem dele e com o aval da ciência.

“... isso não é nem susto, isso é a litera tura que mostra. Você assusta, mas na verdade, está escrito." (P 10).

Há a inda outros que acreditam que o único recurso é ser mais autoritário, agressivo e ameaçador.

“Olha, às vezes a gente tem que até ser assim dura com esse tipo de paciente porque em casa não tem ninguém para pegarno pé [do usuário]. [...] Assim, se ele não seguir o tratamento pode agravar mais ainda, no caso dele. - 'Olha, se você não seguir o tratamento vai piorare você não quer isso para você', né." (P 7)

“É tem que ir pelo emocional, para ela... Tem que falar para ela se gostar e tratar adequado, fazer todo o tratamento. Ah, vou puxar pelo... - 'Como que é a sua vida... Dentro de casa, quantos filhos você tem?' Porque não tem uma coisa que prende mais uma pessoa, uma avó, uma tia... Você fala assim: - 'A sua família precisa de você, você precisa se cuidar...'." (P 14)

"É um tra tamento de choque, eu acho. Então, a partir do momento em que você mostra os riscos, - 'Olha, se você não tratar, os riscos são esses e pode acontec er com você. Aconteceu com seu vizinho, aconteceu com a minha mãe...' Entendeu? De repente você consegue sensibilizar mais. Eu vejo assim. Se eu pudesse levar todo mundo para o pronto-socomo para dar uma voltinha, eles sairiam de lá convencidos, com certeza..." (P 28)

Essa forma de comunicar-se com o usuário não é nova e nem exclusiva dos profissionais participantes desta pesquisa. De acordo com Lacroix et al (1995b, p. 298-9), "a fim de motivar os diabéticos a tratar-se, alguns profissionais de saúde brandem com ameaças de complicações". 
Segundo Berlinguer (1993, p. 152), “assustar as pessoas com a obsessão da doença e da morte é contraproducente, e isso explica o insucesso de muitos programas de promoção à saúde". Em relação a este tipo de comportamento, Maldonado e Canella (2003, p. 55) explicam que “as pessoas que utilizam amplamente essa forma de comunicação são as que acham que seu próprio modo de pensar e de atuar é o único correto; daí a necessidade de criticar ou de tentar converter os desviantes".

Esse tipo de abordagem vem confimar que o profissional de saúde não trata o usuário como adulto, com capacidadese potenciais para lidar com a doença e o RT. Ao contrário, trata-o de maneira infantilizada, como um pai que detemina tarefasao filho para que ele obedeça.

Em relação a esse comportamento do profissional, Maldonado e Canella (2003, p. 54) afimam que a raiz de muitas condutas de não-a desão reside nessa maneira de tratar o usuário: “o cliente-filho sente-se triunfante quando consegue, mesmo em seu próprio prejuízo, desobedecer as ordens do profissional-pai que, por fim, sente-se initado, enraivecido e imobilizado".

O interessante é que essa conduta do profissional de saúde é ambivalente e contraditória, pois ao mesmo tempo em que trata o usuário como criança incapaz, exige que ele passe a exercer responsabilidades que apenas adultos são capazes de assumir.

Essas considerações deveriam ser uma preocupação do profissional de saúde que se interessa que o usuário tenha confiança nele, pois como chegou à conclusão Wissow (2004, p. 4), depois de examinar diversos estudos sobre comunicação entre profissional e cliente, a confiança do cliente no profissional está primariamente centrada na convicção de que o último é capaz e está disposto a buscar os interesses do primeiro. O autor também concluiu que a confiança parece ser desenvolvida ao longo do tempo e como resultado de ações específicas do profissional que demonstra honestidade, competência e compromisso em agir em nome do cliente.

\subsubsection{Sempre, sempre, sempre}

Como mostram os relatos a seguir, os profissionais de saúde ouvidos nesta pesquisa, pensam que a conscientização do usuário deve ser feita constante e 
insistentemente, fazendo com que ele saiba o que pode lhe acontecer quando não a dere ao RT.

\footnotetext{
"Eu acho que é assim: ele vem, eu conscientizo ele, falo para ele. Outra vez ele vem e está alta. Eu continuo falando a mesma coisa porque eu acho assim... É igual a aquele ditado 'Água mole em pedra dura, tanto bate até que fura'." (P 28)

"Então, ele sempre tem que ser orientado para que ele possa realizar... E tratar sempre para evitar complicações. Sempre. Sempre. Sempre. Sempre." (P 26)
}

Em seus relatos, o usuá rio confima que as conseqüências da não-a desão ao RTé um assunto abordado na interação de maneira insistente e repetitiva.

\footnotetext{
“Eles falam muito. Isso é repetitivo. Sempre, sempre. Nas consultas e nas reuniões também. Se não seguir, eu posso às vezes não morrer, mas ter uma complicação e ficar numa cama. Isto eles costumam alertar. [...] Isso eles explicam direitinho, falam... Isso a pessoa tem que se amar, amar a si próprio para poder seguir à risca o que o médico... O médico não impõe nada, ele só fala o que a pessoa tem, agora, se não quiser seguir, as conseqüências serão desastrosas. Isso eles falam... Se não seguir..." (C 17)
}

“Não, isso o Dr. fala direto para mim. Que é para eu não teimarporque é um perigo. Eu estou correndo risco de um infarto, um derrame..." (C 24)

Sem dúvida, é importante que o usuário esteja consciente do que acontece em seu corpo, os riscos que corre e do que é preciso fazer para manter a doença sob controle e reduzir as possibilidades de complicações, melhorando sua qualidade de saúde e de vida. Entretanto, a conscientização concebida dessa maneira toma a conversa sobre riscos essencialmente repetitiva (LACROIX et al., 1995b).

O profissional de saúde, ao considerar que a conscientização deve ser realizada desta foma, não compreende a adesão ao RT como um processo no qual, geralmente, há um espaço, às vezes grande, entre a consciência e a ação e que, na maioria das vezes, é preciso tempo para que essa última aconteça. 
De outro modo, o profissional de saúde está desconsiderando que o cliente hipertenso não é apenas corpo. Ele é um ser com outras dimensões [psicológicas, sociais, emocionais, espintuais, ambientais, culturais] e, portanto, está sujeito a influências diversas que podem contribuir ou prejudicar a sua consciência do problema. Está desconsiderando também os processos individua is de aprendizado do usuário, os quais precisam de tempo para ser sedimentados, além de respeito às diferenças pessoais de cada um. Dimensões essas que se manifestaram nos seus relatos e revelaram suas fomas de pensar e agir diante da doença e do regime terapêutico.

De acordo com Blummer (1969), um conceito central no Interacionismo Simbólico é o de objeto social - "construtos humanos e não entidades autoexistentes com natureza intrínseca" (p. 68). Segundo Charon (1998), os objetos são socia is porque por meio da interação social são indicados, isolados, catalogados, interpretados e conferidos signific ados a eles. Cada pessoa confere um signific a do próprio aos objetos que pode coincidir com o do outro ou não. Damos nomes a eles, aprendemos na interação para quê eles nos servem e como serão usa dos.

Até agora, da interação entre o profissional de saúde e o usuário, é possível perceber que existem vários objetos socia is. Por exemplo, a intera ção, o RT, o SUS, o serviço de saúde, a adesão, o próprio usuário e o profissional, entre outros. Todos eles definidos pelo profissional de saúde e pelo usuário a si mesmose para o outro e aplicados na situação de interação e, como será visto mais adiante, fora dela.

Outro conceito central no Interacionismo Simbólico é o de símbolo - um tipo de objeto social usado para representare comunicar.

$\mathrm{Na}$ perspectiva do Interacionismo Simbólico, qualquer coisa pode ser um símbolo - palavras, objetos, linguagem, atos, perspectivas, concepções, entre muitos, desde que seja significativa, quer dizer, desde que a pessoa que a usa, entenda o que ela representa. Dizer que um símbolo representa alguma coisa, é dizer que quem o emprega entende seus próprios a tos (CHARON, 2000).

Qualquer coisa poderá ser um símbolo se também for usada intencionalmente. "A pessoa que usa os símbolos faz isso com o propósito de produzir o significado que ela acredita fará sentido para a outra pessoa" (CHARON, 1998, p. 48). Isso toma a comunicação entre os atores, simbólica e, em certa 
medida, controlada por eles. "Os símbolos são compartilhados entre as pessoas, e tudo que elas decidem tomar um símbolo passa a ser um" (CHARON, 2000, p. 189).

Segundo Charon (2000), desde que nascemos, por meio da socialização, aprendemos com nossos socializadores [p. ex.: pais, professores] a lidar com as situações. Eles são usuários de símbolos e nos ensinam por meio de símbolos. Nós os adotamos, então, e eles passam a ser nossos, para nosso uso. Transformamo-nos, então, em seres capazes de pensar, escolher, controlar o eu e, enfim, romper com os controles dos soc ia liza dores.

$\mathrm{Na}$ explanação sobre a interação entre o profissional de saúde e o usuário feita até agora, é possível perceber que ambos utilizam-se de vários objetos sociais e símbolos para representar e comunicar-se. O principal símbolo do qual o profissional lança mão é a conscientização. Em resposta a ela, o usuário ta mbém emprega símbolos para comunic ar-se com ele.

\subsection{O usuário na interação e fora dela}

Os relatos do usuá rio mostram que, como resulta do da interação, o usuá rio constrói suas acepções, perspectivas, capacidades e percepções que tem sobre seu problema de saúde, o tratamento, a adesão / não-adesão ao RT, o risco de complicações, entre outras coisas, que demonstram seu modo própro de vê-las e agir.

\subsubsection{A hipertensão arterial e o regime terapêutico: conhecimento e aprendizado}

Em relação à $H A$, a maioria dos usuários pesquisados tem algum conhecimento sobre a doença que parece ter sido obtido, na sua maior parte, a partir do contato com os profissionais de saúde e da experiência que ele próprio tem com a enfermidade.

De modo geral, ele descreve a HA como uma doença perigosa, sem cura, apenas controlável e que acarreta complicações e morte. Sabe que alguns fatores a provocam ou alteram, como a idade, o sedentarismo, o álcool, o estresse e o sal. 
Também sabe que precisa adotar medidas famacológicas e não farmacológicas para controlar o seu problema de saúde.

\footnotetext{
“Essa hipertensão, todo mundo sabe, não tem cura. Pode remediar, tomar remédio... E a pessoa precisa ter muita precaução no tratamento - não deixar de tomar o remédio. Se deixar de tomar o remédio... Porque a hipertensão é uma coisa que vem de repente. Como é que se fala...? Assassina, né. [...] Essa doença vem... natural... eu creio que vem devido à idade também. [...] E quem não faz caminhada, só fica em casa ou anda só de carro, é mais fácil bater a pressão alta. Qualquer excesso que faz, sobe. [...] O problema é a pressão porque a pressão mexe com o coração." (C 22)
}

Estudos têm mostrado que a maioria dos hipertensos tem o conhecimento básico da sua doença (STRELEC; PIERIN; MION J R, 2003; PÉRES; MAGNA; VIANA, 2003; BASTOS; BORENSTEIN, 2004), mas também superficial, insuficiente e às vezes distorcido.

Alguns usuários participantes desta pesquisa, por exemplo, revelaram que gostariam de saber ma is sobre sua saúde, sobre o que está acontecendo no seu corpo, o motivo dos seus sintomase também sobre os medicamentos.

\footnotetext{
"Eu a cho que a gente deveria ter ma is explic ação sobre ela [a hipertensão]. Por quê? Quais os danos que ela pode causar no caso de ela elevar? Se eu posso ter um desmaio no lugaronde eu estiver? De repente eu posso estar lá no centro e ela elevar mais e eu não estou sabendo. E eu não sei a medicação... [...] É por isso que eu falo, dependendo do dia é que ela tem essa a lteração. Ela altera conforme o dia, sei lá a hora. Isso é que eu gostaria de ter explicação." (C 11)
}

Há estudos que ta mbém demonstram que, embora haja conhec imento, nem sempre há compartilhamento de significados, ou seja, não se pode dizer que o significado da doença para osusuários seja o mesmo para os profissiona is de saúde. Conforme Muela et al. (2002, p. 411) a fimam, "se as mensagens de saúde são bem entendidas pela população, o significado dado a elas pode diferir consideravelmente do que os profissiona is de saúde pretendem tra nsmitir". HeurtinRoberts e Reisin (1992), descobriram que a maioria dos pacientes que eles pesquisaram conferiam à HA dois tipos de significado, enquanto os profissiona is apenasum. 
Nesta pesquisa foi constatado que, embora o usuá rio demonstre um certo grau de conhecimento sobre seu problema de saúde, ele tem dificuldade para lembrar do RT como um todo. Com exceção das medicações, que alguns até apresentam o nome e a posologia, as medidas não farma cológic as de controle da HA são lembradas a penas com estímulo.

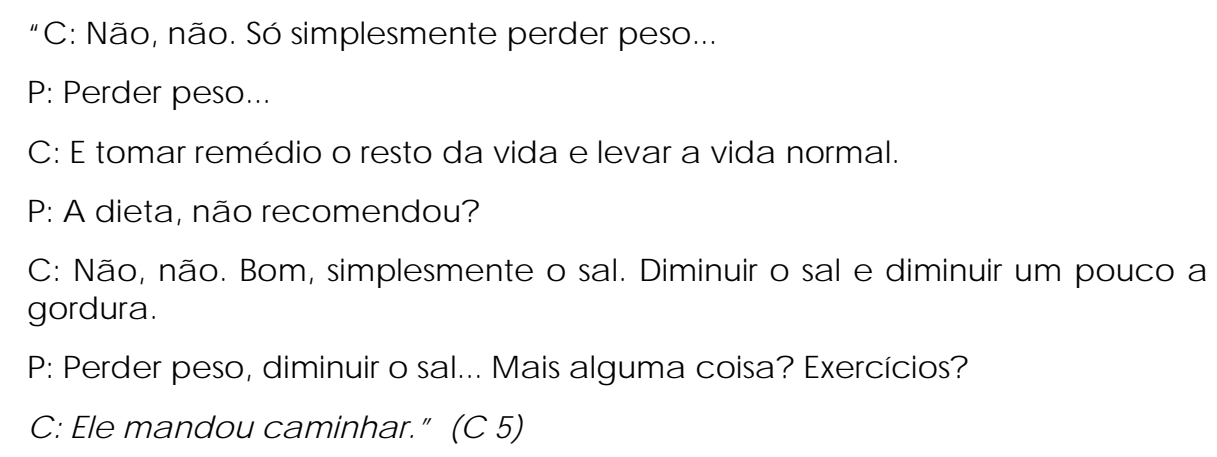

“C: Não... Eu vou lá eles passam o remédio e venho embora. Aí temina esse, eu volto lá, tomo a consultar, pego o remédio...

P: É só medicação?

C: É só medicação.

P: Não falaram para a Sra. fazer outrascoisas além da medicação?

C: Só ca minhada.

P: Só caminhada?

C: E a comida que tem que ser sem sal, menos gordura. Então, só isso que elesfalaram para mim." (C 9)

Como mostram os diálogos a cima, a maioria dos usuá rios usa a palavra "só", quando indagados sobre essas medidas. Isso talvez seja uma forma de o usuário restringir os itens do RT àqueles que provavelmente ele considera possíveis de realizar, numa tentativa de simplificar o RT, diminuindo a sua complexidade.

Pode ser também que o RT não esteja sendo suficientemente intemalizado pelo usuário. Em relação a isso, supomos que uma explicação seja a de que a forma como as medidas não farmacológicas são abordadas pelo profissional de saúde não é convincente.

Isso remete a um outro ponto, a informação que o usuário recebe do profissional de saúde pode ser muitas vezes abstrata e, portanto, de pouco impacto, mesmo sendo transmitida de forma persuasiva. O profissional, por 
exemplo, deixa de trabalhar conceitos abstratos em termos concretos, de forma que o usuário possa sercapaz de entendê-los, assim como lhe falta a habilidade de colocar as informações sobre a HA e o RT em um contexto apropriado de maneira a não permitir que o usuário tenha idéias emôneas sobre eles.

Como será visto, os exemplos concretos presenciados pelo usuário têm influenciado sua maneira de agir muito mais do que as informações do profissional, demonstrando que as mensagens mais facilmente intemalizadas são aquelas ligadas ao que ele já conhece ou experimentou.

Outra possibilidade é a de que o usuário não dá muita importância às medidas não farmacológicas, o que parece provável. De modo geral, os dados parecem indicar que os usuários partic ipantes desta pesquisa têm uma perspectiva de adesão ao RT mais relacionada ao consumo da medicação. Uma explicação para isso pode ser a de que o profissional de saúde está enfatizando mais o tratamento medicamentoso em detrimento das medidas não-famacológicas [embora em seus relatos eles digam que não]. Essa hipótese é provável, pois em estudo realizado com médicos brasileiros Mion Jr, Pierin e Guimarães (2001) descobriram que a maioria deles (62\%) infomou que recomendavam o tratamento não farmacológico somente para $25 \%$ dos seus pacientes e só $17 \%$ recomendavam para todos eles. Segundo Krasilcic (2001), há informações de que os médicos não acreditam, não estão habilitados ou não têm disponibilidade de prescrever e orientar as medidas não farmacológicas.

Qualquer que seja o motivo, o fato de haver comprovação de que "a combinação de terapias não-medicamentosas, principalmente redução do peso e do consumo de sódio e prática de exercícios regulares, tem se mostrado com eficácia comparável à de tratamentos medicamentosos" (KRASILCIC, 2001, p. 52), mostra que esse resultado constitui-se em elemento de alerta aos profissionais de saúde para uma abordagem mais profunda e elaborada sobre as medidas não farma cológic as junto a os hipertensos.

Pudemos apreender que o saber do usuário sobre a HA e o RT é adquirido num processo gradual de entendimento, evidenciando que a informação transmitida a ele leva um tempo para ser intemalizada e sedimentada.

"Eu achava que o medicamento tinha que fazer efeito junto com todas as coisas que eu fazia. [...] Mas depois entendi que eles estavam explicando a doença que eu tenho. Estavam apenas alertando porque não foram eles 
que me fizeram a doença. Eu cheguei lá com a doença, então eles estão explicando o risco que eu como. Mas custei a entender isso. [...] A ignorância é fogo!" (C 17)

“P: O Sr consegue entender as orientações?

C: Quase todaseu consigo.

P: O que o Sracha difícil?

C: Olha, talvez ele possa fazer uma orientação lá que na hora a gente fica meio em dúvida. Depois, devagarzinho que vai chegando à conclusão da orientação que ele deu." (C 21)

Este resulta do vem de encontro a o que Grueninger (1995) afima, a partir da teoria andragógica de Knowles, sobre o aprendizado de pessoas adultas. Primeiro, que o aprendizado do adulto é auto direcionado, ou seja, ele começa a aprender quando reconhece uma lacuna ou disparidade entre o que ele sabe e o que ele quer saber. Segundo, que o aprendizado é construído sobre sua experiência de vida que é utilizada como um recurso para resolver novas tarefas e/ou problemas. Terceiro, que o aprendiza do serve para ele desenvolver seus pa péis socia is. Por fim, que o aprendizado é orientado para aplicações imediatas e resolução de problemas da vida real.

O hipertenso, portanto, a o contrário do que o profissional de saúde pensa, não toma consciência de sua necessidade de aderir a o RT simplesmente ouvindo-o repetidamente falar sobre a doença e as complicações. Antes, tem um modo próprio de entender e elaborar essas informações.

\subsubsection{Significado do regime terapêutico e da adesão}

Nomeado às vezes como ordem, às vezes como pedido ou mesmo como conselho, para o usuário, o RTtem o signific ado, em primeiro lugar, de ações que o profissional manda fazer e ele tem que obedecer. Por dedução, é possível inferir que o usuá rio ta mbém entende a adesão como um a to de obediência.

“O médico fazo pedido, a gente tem que obedecer, né. [...] Seria bom se a gente tivesse um remédio que curasse de uma vez, mas é difícil, então tem que obedecer às ordens dos médic os." (C 23) 
“Eu acho que é uma ordem médica. Deu uma ordem para mim que eu tenho que seguir essas nomas. Então, eu tenho que seguir essa ordem." (C 21)

A concepção de obediência à prescrição tem sido difundida ao longo dos anos, por meio da mais conhecida definição de adesão ao RT: “o grau de coincidência existente entre o comportamento do paciente e a prescrição médica em temos de freqüência às consultas, dietas, tomada da medicação e outras orientações" (HAYNES a pud ORTEG A; NOBRE; MION J r, 2001).

Nesse conceito está compreendida a idéia de que o paciente deve ter um comportamento apropriado diante da prescrição do profissional de saúde, pressupondo que tal comportamento deva ser de submissão incondicional ao que o profissional detemina, visto que tem que "coincidir" (grifo nosso) com o que este último lhe designa.

De igual modo, pressupõe que a centralidade das decisões está em poder do profissional, de modo mais intenso nas mãos do médico, deixando ao paciente pouco ou nenhum poder decisório.

É uma perspectiva patemalista, baseada no modelo biomédico de atenção, que define o comportamento do doente nos termos das expectativas do profissional de saúde e no qual ele se considera detentor do que seja melhor para o usuário, acreditando que, porisso, deve seguir o que lhe é deteminado.

Essa análise é fundamentada no estudo de Stimson (1974) que procurou saber em uma revisão de vários estudos sobre adesão a o tratamento medicamentoso, por que os pesquisadores [que também eram profissionais] consideravam que os pacientes deveriam aderir. Ele concluiu que

[...] é porque o médico é visto como a única pessoa que é legitimamente capaz de fazer declarações formais sobre o uso de medicamentos. Ele é o expert: o paciente deve acreditar nele e somente nele (exc eto, é claro, em outros médicos, mas mesmo assim sob certas circunstâncias tal como num encaminhamento). É o médico que sabe o que é melhor. Assim o paciente é para ser passivo, obediente e não questionar. (STIMSON, 1974, p. 100)

Desta forma, a visão de que o usuá rio deve obedecer às suas deteminações está entranhada nas concepções e práticas dos profissionais e é essa mensagem 
que é passada na interação para o usuário [de forma consciente ou não]. Na maioria das vezes, por não ter todas as condições para submeter à crítica as palavras do profissional de saúde, o usuário acaba reproduzindo essa concepção.

\footnotetext{
“Tudo que eles falam é certo. Eles falam - 'Quer viver mais, então, tem que seguir à risca, tem que seguir o certo'. A gente quer viver mais, então tem que seguir. Eu acho certo. Bastante." (C 20)
}

"[Eles falam] para a gente compreender que tem que ser seguido à risca o que o médico passa sobre a alimentação, sobre a hidroginástica que a gente faz. Tem que seguir." (C 17)

"Ah! Ele fala que é obrigado a tomar o remédio. Tem que tomar o remédio certinho, que não podia esquecer a hora certa,..." (C 23)

O significado que o RT e a adesão têm para o usuário, portanto, deriva da forma como lhes têm sido a presentados pelo profissional de saúde na interação.

Para o usuário, o RTe seu seguimento são coisas que ele não gosta de fazer, pois julga que é ruim ter tantas responsabilidades, ter que mudar seus hábitos e abdicardo que gosta.

“Não é legal não, seria bom que a gente não usasse nenhum remédio. Se tivesse outra forma... De ter aquela responsabilidade de todo dia tem que estar tomando a medicação. Levantou, a primeira coisa que tem que fazer é tomar um café, tomar um copo de leite e já tomar... [o medicmento] [...] Ah, lógico que é ruim, é uma responsabilidade, não é. É uma responsabilidade da parte da gente. Você não pode esquecer hora nenhuma." (C 11)

“Olha, eu não acho bom porque quando a gente tem a saúde boa, é outra coisa. Quando a gente perde a saúde, precisa estar tomando o remédio todo dia... Não é nada bom. [...] Vamos supor... O café, eu era viciado desde o tempo de criança. Fui obrigado a largar por causa da pressão. Comer comida... Tem que comer só cozido. Lá um dia assim eu como uma farinha assada porque não pode comer frito, né. Então, tem muitas coisas que a gente gostava e a gente é obrigado a deixar de comer." (C 23) 
Castro e Car (2000), numa investigação cujos objetivos foram descrever o cotidiano da vida de hipertensos após o conhecimento do diagnóstico da HA e identificar possíveis mudanças na dinâmica da vida deles após o início do tra tamento, concluíra m que eles se ressentiam com as mudanças ocorridas nas suas vidas.

Com efeito, a introdução do RT no cotidiano do hipertenso traz mudanças que alteram muito a vida dele e que não são facilmente intemalizadas e aceitas, pois exigem dele um processo contínuo de adaptações físicas, psicológicas e socia is (REINERS et al., 2000). Isso demonstra que o impacto dos eventos e restrições de vida apresentado pela HA não depende só de sua natureza, mas também da interpretação a fetiva e cognitiva que o usuá rio faz deles.

Por fim, conforme mostra o rela to a seguir, para o usuário, a adesão ao RT também tem o significado de que é algo determinado pelo profissional, com a finalidade de lhe beneficiar, ou seja, é para seu benefício.

"A gente vê que é para o bem da gente." (C 11)

“...como se diz, para o bem da gente, para o bem da saúde da gente. " (C 20).

Essa idéia, muito provavelmente, também advém da interação com o profissional de saúde que considera que o RTé o que há de melhor para o usuário e porisso tem que seguir.

\footnotetext{
“Tem que fazer. Não é que... Porque a gente tem que fazer. Se a gente quiser a saúde, tem que fazer." (C 9)
}

Embora seja uma concepção que nem sempre o usuário tem porque espontaneamente percebeu por meio de suas experiências, mas porque o profissional de saúde lhe diz [reproduzindo o discurso do profissional]; inegavelmente a adesão ao RT constitui-se em benefício para a saúde do usuário, 
comprovadamente relatado por diversos autores, declarado em documentos emitidos pelos órgã os oficia is e constata do por muitos profissiona is em sua prática.

\subsubsection{Percepção de risco e cura}

Embora o usuário saiba que a HA pode trazer complic ações e saiba também da possibilidade de morte em conseqüência delas, sua percepção de risco não ocorre só a partir dessa informação e nem sempre é igual àquela que o profissional de saúde tem e tenta fazercom que ele tenha.

Nesta pesquisa, o usuário avalia seu nisco de ter complicações e morrer privilegiando sua vivência como hipertenso, acometido por uma delas ou como testemunha das experiências de outros [família, amigos, conhecidos]. Ele confere às informações recebidas do profissional um valor secundário, ou seja, sua percepção de risco é construída mais com elementos de sua vivência física e espinitual do que com elementos da interação.

“Eu acredito porque já vi casos. A gente vê casosque às vezes a pessoa não está tomando a medicação e de repente... É rápido." (C 11)

Esse resultado vem de encontro ao que Grueninger (1995) afima: a avaliação objetiva de risco dos profissionais de saúde e as percepções subjetivas de risco dos pacientes raramente são idênticas. Segundo Misselbrook e Armstrong (2002), os modelos matemáticos de risco dos profissionais são desenhados para o mundo delese não se ajustam facilmente ao mundo do paciente.

De fato, estudos sobre a percepção de risco de clientes (WALTER; BRITIEN, 2002; BALLARD, 2002) comprovam que suas percepções são baseadas em avaliações pessoais acuradas considerando o significado e a compreensão de risco, a forma como ele é apresentado, as experiências e as crenças das pessoas, assim como a história familiar, o grau do risco e as possibilidades de prevenção.

Nesta pesquisa, foi possível identificar que para o usuário, o fato de a HA ser incurável, também é a lgo difíc il para ele aceitar.

Grueninger (1995) diz que, como a PA é muito variável, é difícil para muitos hipertensos não confundíla com estados de tensão ou nervosismo e aceitar que a pressão alta não está curada quando nomaliza, mas que tem que ser tratada pelo resto da vida. 
Do mesmo modo que ele tem uma percepção distinta sobre a questão dos riscos de complicações, quando o profissional lhe diz que o seu problema de saúde é inc urável, a inda que ciente disso, sua percepção é particular.

Alguns usuários entendem como se o profissional estivesse fazendo uma predição sobre o seu futuro. Sentem-se chocados, ficam revoltados e inconformados. Entendem que, mesmo que o profissional tenha ma is conhecimento que ele sobre a doença, não está capacitado a predizer o seu futuro. Portanto, embora a morte seja anunciada, a predição do profissional de saúde é rejeitada e as esperanças do usuário são depositadas no cuidado divino.

\footnotetext{
"O cardiologista me desenganou - 'Não tem cura! Você vai viver com ela o resto da sua vida'. [...] E eu larguei de tomar remédio. Até que um certo dia eu falei - 'Não, eu estou sendo dopado por remédio. Eu não tenho cura e estou sendo dopado por remédio. Aí eu peguei o remédio e joguei para trás e disse: Olha, Deus me dá saúde'." (C 5)
}

"Ah! Eu não penso em nada. O dia que Deus achar que deve... Pronto, vai morrer... Deusé quem sabe." (C 22)

\subsubsection{Espectro do risco}

Talvez pelo fato de perceber o risco de complicações e a cura de forma partic ular, o usuário a presenta maneiras diferentes de reagir a essa realidade.

Como já foi visto, uns dizem não se importar, pois quem sabe da vida delesé Deus. Outros se conformam que têm que ser cuidados pelo profissional de saúde, embora não deixem de crerque Deuspossa curá-los.

“Olha, eu penso o seguinte: Deus deixou os médic os para cuidar de nós, mas a gente não pode entregar de uma vez. Quando o médico fala que não tem mais jeito, sempre tem o médico dos médicos, não é. Inclusive, eu mesmo sou testemunha de muitas pessoas que foram desenganadas pela medicina e hoje estão curadas. [...] Às vezes o médico olha para a gente e fala assim... - 'Eh! Se prepara porque com essa enfemidade você vai morrer'. Então, quem pode fazerisso conosco é só Deus, né." (C 23)

“Eu ainda tenho a esperança que vou ser curado pela mão de Deus. Deus pode me curar. Deus ressuscitou até Lázaro que havia quatro dias que 
estava morto, então Ele pode curar minha hipertensão. Agora, a parte da medicina, eu tenho que segui-la até o dia em que Deus queira me libertar. Mas se eles falam que não tem cura, é porque não tem cura mesmo. Agora é curável pela parte de Deus." (C 21)

Há ainda outros que dizem que não se preocupam, não têm medo e acreditam que não correm riscos, porque se cuidam.

\begin{abstract}
“Mas não preocupo, não, não preocupo que ela possa causar dano mais sério, eu acho que não. Eu pelo menos do meu lado eu não me vejo assim. [...] Porque eles falam que a hipertensão é ma is... Que quando a gente está passando por um estado emocional ela pode causar até um derrame. Eu já vi muitas pessoas fa larem, mas eu não tenho medo não, eu não. Eu acredito, sei lá, em cima dessa alimentação e tomando a medicação eu acho que consigo controlar." (C 11)
\end{abstract}

Embora o usuário tenha percepções particulares sobre as complicações e a cura, assim como maneiras diferentes de reagir a essas realidades, a maionia deles confere um peso importante a elas.

Na realidade, o espectro do risco que paira sobre o usuário é que se constitui na principal razão para que ele se preocupe em seguir o RT - risco de complicare morrer, nisco de ter a PA alterada, nisco de não ter boa qualidade de vida e até risco de ser culpado pelo surgimento de alguma complicação. A palavra "se" é constante nos relatos, dando a entender que, para o usuário, o seguimento do RTé condicional - se não seguir, complicações, morte ou diminuição da qualidade de vida e saúde podem ocorrer.

\footnotetext{
“Não, porque meu esposo faleceu com problema de coração e a gente fica com medo, né. Porque ele não cuidava. Só quando desc obriu é que foi cuidar." (C 20)

“É porque se não fizer, a enfermidade toma conta da gente e aí termina dando..., vamos supor, morte..." (C 23)
} 
“P: E porque o Sr segue? Mesmo não sendo à risca, porque o Sr segue?

C: Porque a gente sente que se não seguir pode complicar.

P: Complicarcomo?

C: Pode a pressão voltar a subir, dar outros problemas... Então, a gente vai seguindo as orientações do médico para poder manter... Não sair fora das nomas que ele pediu porque depois se acontecer qualquer coisa ele fala 'Não, é porque você saiu fora do que eu recomendei. Se você tivesse seguido, talvez não tivesse acontecido'. Então, eu sigo para poder não ter desculpa depois. Se acontecer alguma coisa ... [...] É por isso que eu tenho que seguir as orientações dele porque se aconteceralguma coisa depois, eu sou culpado. Eu não posso culpar o médico. [...] ....a gente também se preocupa com a saúde e tenta seguir porque eu sei que se eu não seguir, vai complicar, então..." (C 21)

Alguns estudos demonstram resultados semelhantes, evidenciando as reações e sentimentos dos hipertensos frente às complicações e à morte e sua relação com a adesão ao RT. Neles, os autores encontraram que os hipertensos investigados tinham medo das conseqüências da $H A$, da morte e da dependência de outras pessoas, advindas das complicações (PERES; MAGNA; VIANA, 2003; MUÑOZet al., 2003; BASTOS; BO RENSTEIN, 2004).

Outra razão para o usuário se preocupar em seguir o RT, é a expectativa que ele tem de manter a PA sob controle, de viver melhore ter mais saúde.

"Eu sigo porque eu vivo melhor." (C 17).

Nesse sentido, a idéia do RT como benefício é reforçada aqui - se seguir será um bem, pois pode não complicar, não morrer e ter melhor qualidade de vida e saúde.

\subsubsection{Responsabilidade com a adesão ao regime terapêutico}

Quando se trata de responsabilidade sobre o RT, da mesma forma que o profissional de saúde, o usuário entende que este é um compromisso que deve ser dividido entre ele e o profissional, cada um fazendo a sua parte - o profissional 
dizendo para ele o que deve ser feito e ele fazendo o que o profissional detemina que ele faça.

\footnotetext{
"Eu acho que é dos dois. Ele para me orientare eu para seguir. Eu tenho essa consciência agora... Que ele tem que me orientar porque ele é o profissional e eu tenho que ir seguindo o que ele me orienta fazer." (C 17)

“...o médico tem a responsabilidade dele, mas o usuánio também tem porque tem que tomaro remédio certo como o médico manda." (C 23)
}

Como se vê, o usuário com suas próprias concepções e perspectivas sobre a HA, o RT e a adesão a ele, compartilha esses símbolos com o profissional de saúde, a inda que nem sempre confira o mesmo significa do que esse último lhes dá.

Com efeito, conforme diz Charon (2000), o uso de símbolos nem sempre funciona a contento e qua se nunca são compartilha dos com perfeição.

\footnotetext{
Às vezes empregamos símbolos para nos comunicar, mas ninguém nos escuta. Ou então não pretendemos nos comunicar, mas outros interpretam nossos atos como simbólicos. Ou a inda queremos dizer alguma coisa com nossos símbolos, mas os outros pensam que queremos dizer outra. (CHARON, 2000, p. 189)
}

Para que isso acontecesse, seria necessário que os símbolos fossem percebidos e entendidos pelas outras pessoas da mesma forma que quem empregou o símbolo percebeu e compreendeu.

O profissional de saúde age em direção a o usuário tentando conscientizá-lo da importância da a desão ao RT. Simbolicamente, ele procura comunicar-se com o usuário, intencionalmente, ele quer convencê-lo a aderir, mas como será visto a seguir, [parafraseando CHARON, 2000] o uso da conscientização não funciona a contento e quase nunca é compartilhada com perfeição.

\subsection{Administrando o regime terapêutico à sua maneira}

Como foi possível perceber, o usuá rio, no processo de viver e conviver com a HA e o RT, não está inerte. Do mesmo modo que o profissional de saúde guia-se por 
suas convicções e concepções para conscientizar o usuário da necessidade de aderir ao RT, este também manifesta a sua subjetividade, tanto na interação como fora dela, mostrando o outro lado da moeda, revelando a sua capacidade de participar do processo de modo efetivo, mesmo não sendo como o profissional de saúde pensa que tem que ser.

Segundo Santos (2000), embora a relação entre o profissional e o paciente implique em grande desigualdade de perspectivas e o conhecimento flua aparentemente de um só lado para o outro, a passividade do cliente é mera aparência, pois, na realidade, ele dispõe de caminhos socia is a ltemativos capazes de lhe dar satisfação mais próxima de seus desejose sentimentos, que o profissional porvezes não pode lhe fomecer.

Neste sentido, em relação ao RT, a maioria das ações dos usuários pesquisados está compreendida num processo no qual prevalece uma maneira própria de administrá-lo, representando sua forma de aderir.

A despeito do fato de não gostarem do RT por causa das muitas mudanças em suas vidas, por considerarem que seu seguimento é benéfico para sua saúde, que é obrigatório porque o profissional diz que "tem que seguir" (grifo nosso) e, a lém disso, por terem sobre si o espectro do risco, todos os usuários partic ipantes desta pesquisa dizem que no início do tratamento procuram seguí-lo à risca - tentam mudar seus hábitos de alimentação, habituar-se a fazer exercícios, tomar as medicações regularmente, não fumar, entre outras coisas. Mas ao longo do tempo, muitas dessas tentativas se frustram e a maioria decide seguir o RT à sua maneira considerando o que é possível fazer, o que consegue fazer ou o que querfazer.

Administrar à sua maneira compreende ações como a manipulação de horários, a escolha de atividades, o uso de práticas altemativas, decisões de não tomar a medicação ou tomá-la apenas quando tiver sintomas, decisão de parar com o tratamento, entre outras.

\footnotetext{
“A pressão minha eu vinha convivendo com ela a 18 por 12. Nomal. Nunca sentia nada. (...) Eu fiz tratamento uma vez e parei. Agora faz uns dois anos que eu não faço tratamento. Comecei a tomar o remédio, mas aí... Parei com o remédio. (...) Aí chegou um dia que falei - 'Desse jeito vou ser domina do por remédio. Aí parei'." (C 5)
}

"No começo eu senti um pouco de dificuldade porque eu queria seguir à risca a recomendação médica. Eu perdi bastante peso porque eu mudei 
meu modo de alimentar e tudo... comecei a perder peso. Então, aí eu fui abandonando um pouco e fui entrando no ritmo antigo mesmo e voltou à nomalidade de novo. Eu vi que com o remédio está controlada a pressão, então, não estou respeitando muito não. Só estou cuidando um pouquinho do sal. Não sigo à risca, mas sigo. (...) A gente acostuma, pega um hábito qualquer aí e passa a ser parte da vida da gente. A vivência nesse estilo... acabou, não tem outro jeito, tem que seguir nesse ritmo." (C 21)

\begin{abstract}
“Todos os médicos falam que o certo é seguir o tratamento, mas tem isso também... Ficar só naquele remédio toda vida, o organismo acostuma com o remédio. Tem que ter ajuda com remédio caseiro também. Só remédio de droga, o organismo a costuma. Eu tomo remédio caseiro... Faz aí e eu tomo. Às vezes eu também experimento deixar de tomaro remédio por um ou dois dias para ver se não acontece mais, né. Pede para Deus curar... - 'Oh! J esus!' Aí eu deixo de tomar dois, três dias o remédio, mas a pessoa que tem pressão alta, de qualquer maneira vem mesmo o negócio." (C 22)
\end{abstract}

O fato de que pessoas que têm problemas crônicos de saúde costumam manejar o RT à sua maneira, não é um dado novo. Com efeito, estudos têm demonstrado que isso ocorre com uma certa freqüência.

Hayes-Bautista (1976) constatou que os pacientes pesquisados por ele modificavam o tratamento prescrito usando táticas de convencimento e confronto junto a os profissionais. Conrad (1985) constatou que os pacientes que estudou autoregulavam o tratamento reduzindo a dose do medicamento, interrompendo-o por um tempo ou, dependendo das circunstâncias, tomando doses extras da medicação.

Investigando o modo pelo qual os pacientes decidiam o que fazer com as prescrições médicas, Dowell e Hudson (1997) descobriram que eles desenvolviam um processo de testes e decisões o qual incluía o entendimento que eles tinham sobre a doença e o tratamento, seus valores, a confiança nos médicos, entre outros.

Cade (1997, p. 13) ao investigar o comportamento de hipertensos em relação à doença constatou que eles manipulavam o tratamento, selecionando as ações que seriam rea lizadas, quando executá-las ou interrompê-las. A autora comenta: “É como se as pessoas apresentassem predisposição a aceitarem determinadas práticas, de acordo com as prioridades do momento". 
Gonçalves et al. (1999), em estudo com pacientes tuberculosos, evidenciaram que, fundamentados em conclusões sobre os efeitos desejá veis ou não dos medicamentos, eles administravam seu tratamento de modo que as sensações negativas fossem minimizadas. Manejavam a ingestão diária dos medic amentos em função de suas sensa ções corpora is, a lia das a os eventos de seu dia-a-dia.

O principal achado da pesquisa de Durham (1999) com mulheres com risco de ter trabalho de parto prematuro foi que, embora elas entendessem o tratamento prescrito e as razões para ser daquela forma, geralmente modificavam as restrições de atividades por causa dos conflitos que resultavam das demandas provindas do seu trabalho diário dentro de casa.

O estudo de Thome, Paterson e Russell (2003) revelou que os participantes manejavam o RT de vá rias formas, como, por exemplo, mudando a quantidade e o horário dos medicamentos ou comendo mais que o usual. Da mesma forma, Broom e Whittaker (2004) descobriram que os diabétic os que pesquisaram manipulavam sua medicação e os níveis de açúcarno sangue.

\subsection{Efeitos}

Nesta pesquisa, portanto, os resultados mostram que a pesar das ações gera is de atenção à saúde do hipertenso que o profissional de saúde realiza e apesarde seu esforço em conscientizar o usuário, ele não adere ao RT exatamente como recomendado pelo profissional de saúde. O resultado disso é que o usuário é simplesmente visto como a pessoa que não adere e está sujeita a alguns efeitos decorrentes dessa visão.

\subsubsection{Reações do profissional de saúde}

Ao perceber que o usuário não está aderindo a contento a o RT, o profissional apresenta quatro tipos de sentimentos e reações: em relação a si mesmo frustração e chateação porque não consegue fazer o usuário aderir ou imitação, porque não consegue avaliar o tratamento prestado; em relação ao usuário pena, preocupação, tristeza, porque o usuário complicou ou vai complicar; em 
relação a o sistema de saúde, sente mágoa porque ele dific ulta a adesão e, porfim, reage com frieza por considerar que a não-adesão já era esperada.

\begin{abstract}
"Aquele que não segue me imita profundamente porque remédio tem aí. [...] Então ele chega aqui e fala - 'Ah, acabou o remédio faz duas semanas'. Eu fico muito imitado porque você não pode avaliaro tratamento." (P 10)

“Então, essas pessoas que a gente fica sabendo que têm mais problemas de fundo emocional, a gente fica com um pouco de pena de saber que não temos como atuar para controlar essa pressão. Vai a lém até da nossa capacidade e competência. Então eu fico com pena daqueles que têm mais problemas emocionais." (P 25)

“É uma situação, às vezes assim... Como a gente já é formado para lidar com isso, às vezes a percepção da gente, mesmo tentando nos colocar no lugar dele, ela é maisfria..." (P 12)
\end{abstract}

São sentimentos diferentes dos que ele tem em relação a o usuá rio que adere a o RT. São sentimentos de satisfação porque "ela entendeu o que a gente queria dizere faz" (P 27).

"A gente fica feliz porque conseguiu passar a mensagem que a gente quer. Ë exatamente isso que a gente quer..." (P 27)

"As pessoas, assim, que chegam a nos falar que seguem direitinho a dieta, o tratamento, tudo, a gente sente uma sa tisfação muito grande..." (P 13)

Segundo os relatos dos usuários pesquisados, quando ele revela ao profissional que não está aderindo ao RT, alguns profissionais reagem de foma compreensiva, reforçando a necessidade de o usuário continuar tomando o medicamento.

“Olha, nem todos, mastem alguns que entendem." (C 23)

“Dá força, né. Dá força para a gente. Eles conversam com a gente, direitinho, explic am tudo." (C 20) 
Outros, ao contrário, ficam chateados com o usuário, chamam-lhe a atenção, relembrando que ele pode ter complicações e que, se isso acontecer, não é responsabilidade sua, mas do usuário.

\begin{abstract}
“Ontem mesmo eu falei para o Dr. e ele falou - 'Por que você já está teimando? ' Eu falei - 'Eu não estou fazendo nada, só que estou sentindo... Minha pressão em vistas do que estava está a té nomal porque está 14 por 9'. Só que ele passa pito em mim porque eu teimo, ele briga comigo. [...] Esses dias mesmo eles brigaram comigo porque eu fiquei ruim e fui parar no hospital. Eles falaram que foi início de infarto e que eu teimo muito. Eu falei: 'Mas eu não estou teimando...' Aí eles disseram: - 'Está, sim. Está teimando. Não vem falar para mim que não está porque está teimando'." (C 24)
\end{abstract}

“Ele só fala assim - 'O problema é seu! Eu estou fazendo a minha parte. Eu estou fazendo a minha parte. Se aconteceralguma coisa, depois...'" (C 21)

O que há de comum em todos esses sentimentos e reações, mesmo aqueles em relação a o usuário, é a preocupação que o profissional tem com o resultado do seu trabalho. Da mesma forma que considera que a adesão do usuário ao RT é produto do seu desempenho, é mérito seu, quando ela não acontece a contento, fica preocupado porque não conseguiu o êxito no tratamento que, como já foi visto, é muito importante para ele, pois representa a medida do seu sucesso ou fracasso profissional. Segundo Soar Filho (1998), as resistências e boicotes do cliente ao tratamento podem ser fonte de grande insatisfação para o profissional e, dependendo das suas características de personalidade, essas reações podem ser entendidas como um desafio à própria competência ou autoridade dele.

Isso vem reforçar o que tem sido evidenciado nesta pesquisa - a centralidade do profissional na interação - que, como já mencionado, é mais forte na pessoa do médico. Reforça também o que Maldonado e Canella (2003, p. 33) chamam de "ilusão de onipotência". De acordo com os autores, essa ilusão, de certa forma todos nós a temos. O problema existe quando ela ultrapassa o nível humano da conduta, ou seja, "quando alguém tenta desempenhar o papel de semideus, que tudo pode, em vez de funcionar como gente, com capacidades, possibilidades, limitações e fa libilidade".

O resultado disso é que diante das dificuldades ou daquilo que aos olhos do profissional está errado, a fim de lidar com seus sentimentos de ansiedade e riscos 
de fracasso, é freqüente que ele assuma uma atitude repreensiva e autoritária com o usuário, como, por exemplo, criticá-lo severamente pela demora em buscar o serviço de saúde (SOAR FILHO, 1998).

Outro resulta do é que, por ser tão importante para o profissional de saúde ver traduzido o resultado do seu trabalho em sucesso, a adesão a o RT passa a ser o seu foco na interação. Ele passa a se preocupar mais com a adesão do que com o usuário. Centraliza seu foco não na pessoa do usuário, mas na adesão. O usuário não é visto como pessoa com suas vulnerabilidades, habilidades, aspirações e necessidades, mas apenas como alguém que deve concretizar a sua prescrição para garantir o sucesso do tratamento, ou seja, como objeto de realização de algo que o profissional considera fundamental para o êxito do tratamento.

$\mathrm{Na}$ interação, portanto, onde a adesão deveria ser o objeto e o usuário o sujeito, juntamente com o profissional, ocorre o inverso. O usuário é visto como objeto da adesão.

Outra reação do profissional de saúde é que, como num diálogo consigo mesmo [com o self], alguns deles quando vêem que o usuário não conseguiu aderir a o RT, fazem questionamentos tentando a char a causa do insucesso da a desão em si mesmos.

\footnotetext{
"Será que eu fui bastante clara com ela? Será que eu disse o suficiente? Porque eu tenho a minha parte." (P 8)

"Aí eu vou me questionar: Será que eu estou usando a medicação correta? Será que este paciente não é um paciente especial que está... Às vezes a responsabilidade está em mim." (P 12)
}

Maldonado e Canella (2003, p. 35) apresentam uma explicação para essa reação que, pela análise até aqui realizada, pode ser considerada como lógica. Segundo os autores, "quanto mais forte a ilusão de onipotência, mais intensa a culpa onipotente, manifestada pelo medo de cometer falhas imperdoáveis ou causa r da nos irreversíveis". 


\subsubsection{Caractenização do usuánio}

Outro efeito é que o profissional de saúde tende a caracterizar o usuário levando em consideração a adesão / não-adesão ao RT.

Desta forma, o usuário que adere é caracterizado como uma pessoa consciente e esclarecida, além de disciplinada, batalhadora, responsável, comprometida, abnegada e equilibrada. O profissional o considera assim porque acredita que ele está ciente de sua condição de doente e da responsabilidade que tem para consigo mesmo.

"Acho que é uma pessoa que tem consciência da sua necessidade, ele é mais consciente da sua necessidade." (P 25)

“[Acho] que é uma pessoa que está preocupada consigo mesmo, é uma pessoa responsável com ele mesmo." (P 16)

“Eu acho que é uma pessoa mais escla recida, uma pessoa mais controlada, tem mais consciência do seu problema, que sabe da gravidade, que sabe que tem que controlar." (P 13)

O usuário que não adere, seja por causa das dificuldades ou porque não quer, o profissional de saúde o caracteriza como difícil e complicado, inc onseqüente, mas principalmente, teimoso e rebelde.

“Ele é rebelde,... [...] ...se for uma pessoa que não vê a importância do remédio, que não sabe os riscos que corre, quer dizer, ela é inconseqüente, não irresponsável, ela é inconseqüente, ela não tem noção do que pode acontecer." (P 28)

“... aquele que toma a medicação apenas esporadicamente ou quando sente que a pressão está alta, esse aí o relacionamento é ma is difícil porque eu tento conversar e ele não aceita a minha conduta e nem a condição de hipertenso. Então, esse é mais difíc il." (P 25) 


\begin{abstract}
“Olha, esses aí... Tem alguns pacientes que a gente fala: 'Esse paciente é rebelde, ele não aceita'. Na verdade, ele não ac eita a necessidade que ele tem de tomar a medicação. Ele é aquele paciente que ninguém convence ele que ele tem necessidade de tomar a medicação. Ele acha que o médico não sabe de nada, que os enfemeiros não falam coisa com coisa, que ninguém sabe de nada, quem sabe é ele." (P 6)
\end{abstract}

Caracteriza r os c lientes parece ser uma prátic a comum entre os profissiona is de saúde. Stimson (1974), ao realizar uma pesquisa bibliográfica sobre não-adesão ao tratamento medicamentoso, encontrou que as palavras e termos usados nos estudos para descrever o comportamento dos pacientes que não seguiam as instruções do profissional eram não aderentes, desobedientes, não confiáveis, desviados, não cooperativos, entre outros.

De fato, caracterização dos usuários não é algo que só os participantes desta pesquisa fazem. De forma semelhante, os profissionais de saúde pesquisados por Maclean et al. (2002), desc reviam os pacientes que aderia m como motivadose os que não eram aderentes como passivos, pessimistas, desinteressados, entre outras características.

Do mesmo modo, os profissiona is de saúde pesquisa dos por Fineman (1991) caracterizavam os pacientes que não estavam dispostos a aderir às suas recomendações como rebeldes, resistentes, manipuladores, teimosos, refratários e ńgidos.

Nesta pesquisa, o profissional de saúde caracteriza o usuário desta forma por considerar que ele não obedece às suas recomendações, é refratário às suas orientações e não aceita o RT prescrito por ele. Também porque o profissional supõe que o usuário não acredita nas informações que constantemente the são fomecidas; não aceita sua condição de hipertenso e, conseqüentemente, não assume que tem que seguir o RT; que o usuário não se importa com sua saúde, e ainda, que o usuário não tem consciência da gravidade de seu problema de saúde e dos riscosque corre.

Da mesma forma, enfermeiros pesquisados por Hallett et al. (2000), também faziam suposições sobre os pacientes considerando que eles não aderiam ao RTpor serem passivos e essa passividade ocomia porignorância, por falta de motivação ou por medo. Segundo os enfemeiros, o comportamento de não-adesão também ocomia porque o paciente rejeitava o RT prescrito pelo profissional considerando que sabia o que era melhor para ele. Por fim, para os participantes da pesquisa, a 
não-adesão ocoria porque alguns pacientes deliberadamente desejavam impedir a cura ou a melhora, a fim de prolongaras visitas dos enfemeiros.

Essas concepções e suposições que o profissional de saúde tem sobre o usuário que não adere se aproximam daquelas que Leite e Vasconcellos (2003) encontraram analisando estudos de adesão à terapêutica medicamentosa relatados na literatura. As autoras descobriram que a não-a desão era considera da pelos profissionais de saúde como um comportamento desviante e irracional do paciente que agia assim por ignorar a importância do tratamento, por ter pouca educação ou simplesmente por ser desobediente às ordens médicas.

\subsubsection{Responsabilidade pela não-adesão}

Do mesmo modo que o profissional de saúde considera que a responsabilidade pela adesão ao RT é de todos os envolvidos na atenção ao hipertenso, inclusive o usuário, considera também que quando ele não adere, a responsabilidade pela não-adesão [no sentido de culpa] é de todos - do profissional, do serviço de saúde, do SUS, do usuário e de sua família. E, novamente, a concepção é a de que cada um responde poruma parte da culpa.

No que conceme ao profissional de saúde, se ele não orienta adequadamente o usuário, não lhe dá atenção, atende-o muito rápido, com má vontade, se não tem uma atitude empática para com ele ou atende-o com atitude de superioridade, então, pode estar prejudicando a adesão do usuánio ao RT, sendo a ssim, responsá vel por ela.

"O que nomalmente acontece com os médicos... Fica em uma posição
superior e não chega até o paciente, ele se toma uma pessoa chata ou
distante e o paciente não tem como se sentir bem. Então, ele vai fugir de
qualquer jeito desse médico ou procurar os chás caseiros que ele confia
muito ma is." (P 25)

“Também pode ser que o enfemeiro não está dando mais atenção, uma atenção mais adequada porque às vezes a coisa dele é rápida, você conversa aqui e tem coisa sque ficam para trás." (P 16)

“Ela passa por uma pré-consulta mal feita, ela entra num consultório de cardiologia onde o médico só prescreve ou até o clínico geral que trata a hipertensão só prescreve o remédio, manda ela embora e às vezes ela não 
sabe de quanto em quanto tempo tem que tomar o remédio e nem para quê é o remédio. Então, tipo assim, por que aderir ao tra tamento? Ela pode tomar dois, três... não vai tomar... Não sente nada, não sente dor, não sente nada, quer dizer..." (P 28)

Da mesma forma, considera que o serviço e o sistema de saúde têm responsabilidade pela não-adesão quando não fomecem medicamentos, dific ultam o acesso aos a tendimentos e exames, quando é moroso, entre outros.

Dentre os motivos pelos qua is o usuário é responsável pela não-adesão estão os de que ele não leva o tratamento a sério, não faz o que foi deteminado pelo profissional, espera acabara medicação ou não fazos exames pedidos.

\footnotetext{
“Eu vejo que é do próprio usuário... [...] Eu vejo que é da parte do usuário mesmo que espera acabar o remédio para vir. Não é para esperar, já que elessabem que são pessoas hipertensas e que tem o programa." (P 19)

“Então, depende ta mbém do próprio paciente que muitas vezes não leva a sério o tratamento..." (P 15)
}

Como se vê, quando a adesão ao RT não acontece, novamente a responsabilidade é dividida. Cada um assume a sua culpa ou culpa o outro, considerando que já fez a sua parte e que, fora isso, o problema já não é mais dele.

\footnotetext{
"Quer dizer, eu enqua nto enfermeira a minha obrigação é sensibilizar ele do problema... [...] ..se ele como pessoa não quer tratar, a gente fazo que a gente pode, mas eu não posso ser patemal a ponto de ir lá na casa dele e dar o remédio para ele. Eu acho que eu divido a responsabilidade com ele, com o serviço tudo, não é." (P 28)
}

Embora isso não seja claramente assumido pelos profissionais de saúde, pelo serviço de saúde e até pelo SUS, é possível inferir que, por lhe ser impingida a maior responsabilidade na adesão, o usuário passa a ser também aquele a quem cabe a maior parte da culpa.

“O erro do paciente, do próprio paciente, que se nega muitas vezes a enxergar coisas óbvias para ele porque ele pode não ter conhecimento técnico, mas ele sabe que quando a pressão sobe a nuca dói e que isso 
implica num risco. Que o vizinho dele teve um AVC, que o outro morreu, quer dizer, ele tem." (P 8)

No ceme desta perspectiva, está presente a idéia de que adesão e nãoadesão são fenômenos relacionados ao usuário e que o comportamento de nãoadesão representa uma escolha volitiva dele (HULKA et al., 1976). Reside também na concepção de que a HA é uma doença determinada principalmente pelo estilo de vida inapropriado da pessoa e pelo qual ela deve ser culpada. Ainda, da noção de que o sucesso do tratamento é fortemente dependente do comportamento adequado da pessoa. Segundo Broom e Whittaker (2004), as pessoas com diabetes [doença que pode ser comparada à hipertensão, pela sua cronicidade] são freqüentemente culpadas pela sua doença, por não cuidarem de si e falharem em ter responsabilidade apropriada sobre sua saúde.

Assim, a idéia de que ao usuário foram dadas todas as condições para que pudesse aderir e que seus comportamentos inadequados foram decorrentes de escolhas livres e conscientes, é que prevalece. Neste sentido, pensa-se que se o usuário não aderiu, a culpa é dele. Mesmo reconhecendo a existência de várias dificuldades que o usuário tem para aderir ao RT, se imputa a culpa a ele por decisões que nem sempre estão ao seu alcance.

O pior disso tudo é que o próprio usuário acaba ta mbém considerando que a culpa é mais dele. Os seus relatos revelam que, assim como o profissional, ele acredita que a responsabilidade maioré dele.

“Eu considero que é minha. [...] Não, eu acho que não tem nada a ver com o médico não. Se eu seguir a orientação dele, se vier alterar alguma coisa o médico não tem culpa." (C 21)

“A responsabilidade é do paciente, do paciente. O médico manda fazer e se não fizeré problema dele." (C 22)

“Como se diz... Aí já é problema da gente porque se eu não seguir...” (C 20) 
Esse resultado é congruente com os achados de Broom e Whittaker (2004) que descobriram que muitos pacientes sentiam-se culpados por não aderirem estrita mente à dieta prescrita.

Nem mesmo o usuário tem clareza das razões que o levam a tomar sobre si a maior responsabilidade sobre a falha na adesão ao RT, porque parece que, para ele, isso já está implícito. Tudo se passa como se ele pensasse da seguinte maneira: o profissional detemina que eu siga suas recomendações; esse é o papel dele e o meu é o de obedecer. Se eu não seguir, o problema é meu.

Ele a ceita tacitamente essa responsabilidade e, às vezes, a té a presenta uma justific ativa para que a responsabilidade não recaia sobre o profissional.

\begin{abstract}
“Porque se eu não tomar uma responsabilidade e consciência do meu problema, o médico tem tanto paciente para ele cuidar e não vai se importar comigo. Agora, eu que tenho que ser responsável e procurar o médico. Eu tenho que ser responsável por mim. Se eu não for responsável por mim..." (C 21)
\end{abstract}

Entretanto, alguns usuários consideram que uma parte da responsabilidade pela não-adesão ao RT também é do serviço de saúde e do SUS, devido aos problemasque ele enfrenta no dia-a-dia em busca de atenção à sua saúde.

\footnotetext{
“A responsabilidade é também do SUS. Agora, por exemplo, vou consultar o médico aí. Agora toda consulta no posto, o médico que tem que encaminhar para o especialista. Chega lá vai agendar. Depois que agenda, eles chamam e vai consultar. Se tiver que fazer algum exame, tem que agendar novamente. A té lá, já passou um mês e se a pessoa agüentar... Se estiver grave, morre. Se não estiver grave, não morre, espera o exame." (C 22)

“É o serviço. Quem é hipertenso não pode ficar sem o remédio. Eles mesmos falam que não pode e vai lá não tem o remédio, vai lá e não tem quem entrega. [...] Muitas vezes a gente vai lá... O dia que der para consultar a gente consulta, o que dia que não dá, tem que esperar. Esses dias mesmo fiquei mais de duas semanas sem o remédio porque eu ia lá, diz que a menina que entrega o remédio de hipertenso não estava, outra hora ela não veio, não tinha o remédio, fiquei mais de duas semanas. Eu falei lá 'Como que eu vou ficar, eu não posso ficar sem o remédio'." (C 9)
} 
Esse resultado se assemelha aos achados de Fortes e Lopes (2004) que, ao analisa rem junto a hipertensos os fatores que influenciavam no controle da pressão arterial, encontraram que mais da metade dos pacientes entrevistados (55,3\%) contestavam a facilidade de acesso ao serviço de saúde. 


\section{PARIE 5 - DISCUSSÃO}

Nesta pesquisa, procuramos compreender, a perspectiva do profissional de saúde e do usuário hipertenso sobre a interação que ocorre entre eles no contexto da atenção em unidades públicas de saúde e analisar de que forma essa interação contribui para a não-adesão do usuário ao regime terapêutico.

Um dos nossos pressupostos era o de que o profissional de saúde age na interação de acordo com suas perspectivas, concepções, significações sobre o cliente, sobre a relação que tem com ele, sobre a doença (HA) e o tratamento, bem como sobre a adesão e a não-a desão a o regime tera pêutico.

O outro pressuposto era o de que o cliente também age na interação e fora dela, conforme os signific ados, as percepções, concepções e perspectivas que tem sobre a hipertensão, o tratamento, o profissional de saúde e a sua relação com ele, assim como sobre a adesão e a não-adesão a o regime terapêtico.

Por meio da proposição teórica fundamentada nos dados que obtivemose na a ná lise e interpretação dos resultados encontra dos, foram expostos a spectos da interação entre o profissional de saúde e o usuário que confimam nossas suposições.

Tínhamos, ainda, o pressuposto de que a não-adesão do cliente a o RT ocorre devido à maneira como o profissional de saúde age e interage com o usuário.

Não podemos afimar que os profissionais de saúde participantes desta pesquisa são responsáveis pela não-adesão dos usuários ao RT. Entretanto, consideramos que os resulta dos encontra dos nos possibilita m compreender que da forma como a interação entre o profissional de saúde e o usuário hipertenso está sendo realizada, em alguns aspectos pode estar contribuindo para a não-adesão desse último ao RTe isso confima, em parte, o que havíamos suposto.

O primeiro aspecto é o de que a interação entre o profissional de saúde e o usuário é pautada basicamente no modelo biomédico de atenção. O mesmo privilegia ações presc ritivas e rotineiras foca lizadas no corpo, na doença, no RTe na adesão em detrimento de ações para e com o usuário. Trata-se de um modelo tradicional cujo saber é fragmentado, hierarquizado e que não considera a partic ipação do usuário no seu processo de cuidado à saúde. 
Este tipo de atenção, nada mais é do que a reprodução de um modelo de assistência que, ao longo dos anos, vem se repetindo, mesmo com o advento de novas formas de assistir as pessoas com problemas crônicos de saúde. Segundo Caprara e Franco (1999), embora a medicina tenha obtido avanços consideráveis em diversas áreas, a partir do século XIX, as dimensões humana, vivencial, psicológica e cultural da doença foram desprezadas.

Outro aspecto é o de que a interação entre o profissional de saúde e o usuário é sem equilíbrio e assimétrica, centralizada no profissional que exerce o papel ativo, enquanto o usuário é deixado na periferia da atenção, desempenhando o papel passivo. É uma relação desigual cujo controle está nas mãos do profissional de saúde e, na qual, ao usuário, não é dada a oportunidade de compartilhar esse poder.

Uma interação na qual o profissional apropria-se de sua condição de formação privilegiada, do seu saber, submetendo o usuário à sua forma de entendere lidarcom a HA e o RT, negando-lhe o benefício da troca, da disc ussão e do conhecimento aprofundado de sua condição.

O desequilíbrio mostra-se na interação também em relação a os interesses divergentes entre os atores, pois enquanto o usuário quer uma relação mais acolhedora na qual o profissional de saúde tenha atitudes e comportamentos que demonstrem interesse por ele [dar atenção, ouvir, dialogar], o profissional preocupa-se com a confiança do usuário nele e nas coisas que ele lhe diz. Quer dizer, enquanto o usuário busca atenção para si, o profissional quer que toda a atenção seja voltada para ele.

É importante destacar que a confiança é central para o cuidado e conforto que toda pessoa doente busca na interação (LUPTON, 1997). Neste sentido, é bom que o profissional queira que o usuário confie nele. Todavia é igualmente importante que ele não apenas queira que o usuário tenha confiança nele, mas demonstre igual interesse em desenvolver confiança mútua, pois toda relação precisa disso.

A interação entre o profissional de saúde e o usuário, nesta pesquisa, é desigual também porque é conferida ao último a maior carga de responsabilidade pela a desão ao RT. O jugo é desigual, pois o usuário não apenasé deixa do sozinho no processo de adesão, como dele é esperado que siga estritamente o que lhe é 
recomendado. Além disso, o profissional pensa que o usuário é quem deve ser seu parceiro, ajudando-o a controlar a HA ao seguir as suas recomendações.

O pensamento de que o usuário deve ser o parceiro do profissional no controle da HA é recorrente na literatura. Entendemos que há um equívoco nesta idéia de parceria. Não é o usuário que tem que ajudaro profissional e sim o inverso [pelo menos nos moldes em que a interação está ocorrendo]. Isso porque cabe ao usuário a parte mais complexa e difícil do objetivo a seralcançado: introduzir novos hábitos ao seu estilo de vida, modificar alguns e abolir outros. Cabe a ele, também, a administração de sua vida e de seus problemas de tal forma que não venham interferir no seu emocional e prejudic aro controle da PA, entre outras coisas.

Profissional de saúde e usuário devem ser parceiros. Entretanto, nessa relação assimétrica, o primeiro tem mais e melhores condições que o segundo, tanto individualmente quanto em equipe, de ter conhecimento, capacidades e habilidades para lidar com o controle da HA. Não é justo que ao usuário caiba a maior carga - a de aderir -, sem que, contudo, lhe sejam dados os meios para que possa desenvolver suas funções em igualdade de condições, como, por exemplo, conhecimento amplo e adequado, suporte social e emocional, acesso a o sistema de saúde e medicamentos, entre outros.

Parceiros caminham juntos, mas é o mais habilitado, capacitado e forte que ajuda quem não tem isso a seu favor. O profissional de saúde pode ajudaro usuário sendo seu parceiro no processo de adesão, permitindo que vivencie cada etapa, cada tarefa como um aprendizado no qual há falhas, mas também acertos e conquistas. Nesse processo, permitir que ele expresse suas dificuldades e faça questionamentos num clima de diálogo e confiança mútua, acreditando que gradualmente emergirá à consciência tudo o que ele precisa para melhorar a adesão ao RT.

Outro aspecto da interação entre o profissional de saúde e o usuário que pode estar contribuindo para a não-adesão do usuário ao RT é o fato de que a maioria dos profissiona is de saúde participantes desta pesquisa trata o usuário com cordialidade, no entanto, sem conseguir concretizar o acolhimento que diz ser importante e que, também, o usuário espera.

Segundo May (1995) certamente é boa a evidência de que os pacientes respondem bem à informalidade e à civilidade por parte dos profissionais de saúde. Mas se eles não se verem como ativos, colaboradores, parceiros no cuidado, ou 
como "experts" em sua própria saúde, podem resistir às ações do profissional e facilmente serem categorizados como pacientes que não aderem.

A realização deste estudo nos permitiu concluir que a principal ação que o profissional de saúde utiliza para fazer o usuário aderir ao regime terapêutico - a conscientização - é um dos aspectos ma is relevantes na contribuição da interação entre o profissional de saúde e o usuário para a não-adesão desse último a o RT.

Como foi visto, a conscientiza ção é considerada pelos profissionais de saúde como atividade educativa e, neste sentido, é louvável que o profissional de saúde queira educaro usuário com o intuito de promovera sua adesão a o RT.

Entretanto, ao conceber e realizar essa atividade na sua forma tradicional, ou seja, como um repassar de conhecimentos ao usuário, considerando o educador como aquele que sabe e o educando como o que não sabe e que, portanto, deve receber passivamente os conhecimentos advindos da sua autoridade profissional, desconsiderando as diferentes formas e ritmos de apreensão do conhecimento, não está contribuindo para que o objetivo pretendido seja alcançado.

Conhecimento não é algo que, de modo geral, o profissional de saúde transmite com presteza e abundância. Em geral, fomece-o de maneira pouco elaborada, na forma de informações insuficientes e nebulosas, e com pouca adequação às reais necessidades do usuário. O profissional não tem interesse na troca, no conhecimento que o usuário tem para compartilhar com ele. Essa atitude significaria, entre outras coisas, dar mais independência ao usuário, ma is poder de decisão, o que implicaria em perda do seu poder, perda da capacidade de mantero usuário dependente dele.

Neste sentido, é preciso que o profissional de saúde repense suas ações de saúde, suas falas, atitudes, comportamentos e estratégias, bem como incorpore novos modelos de educação em saúde, com abordagens que dêem elementos para o usuário escolher com liberdade o que quer fazer com seu corpo, sua saúde e sua vida.

Mesmo que haja distância intelectual entre o profissional de saúde e o usuário, é importante que isso não seja usado como instrumento de poder. 0 conhecimento não pode ser usado como forma de deteminar, agredir, diminuir ou 
discriminar. Antes, deve ser utilizado para ajudar, cooperar, acrescentar, complementar, clareare a poiar.

É importante também que o usuário não seja concebido como um ser passivo que simplesmente recebe informações e prescrições que prontamente tem que seguir. Pelo contrário, ele deve ser visto como um ator que ativamente interage consigo mesmo, com outras pessoas e com o seu meio, apreendendo o que lhe é signific ativo e fazendo suas escolhas livremente.

A educação deve ser um trabalho que implique na interpretação dos processos de saúde-doença a partir de múltiplos referenciais, considerando que educadorese pessoas a serem educadas possuem saberes complementares, sendo parceiros na luta por melhores condições de vida e saúde. Da mesma forma, devese, na educação, incluir a participação e o diálogo entre os diversos saberes, procurando ajudar as pessoas a compreender as raízes de seus problemas e buscar soluções compartilhadas para melhorar sua qualidade de vida (WENDHAUSEN E SAUPE, 2003).

O profissional de saúde somente poderá contribuir mais efetivamente para melhorar a adesão do usuário ao RT se, na ação educativa, como dizem Wendhausen e Saupe (2003), estabelecer uma relação com o usuánio na qual a comunicação passe a ser mais horizontal, se privilegiar o diálogo entre saberes diferentes que se complementam, se respeitar o outro e a sua alteridade, se tiver uma concepção positiva de saúde e acentuar os recursos das pessoas ao invés da carência, e se promover a participação e empoderamento do usuário, individual e coletivamente.

Além disso, se junto com o usuá rio identificar condições que influenciem de forma favorável ou não seus comportamentos em relação à HA, ao RTe a adesão, bem como seu conhecimento, crenças, sentimentos relativos a eles, suas dific ulda des cognitivas e sensitivas, suas facilida des, motivações, entre outras coisas. Trabalhar com o usuário as ações que ele decida realizar por vontade e crença próprias (não porque o profissional manda), estimulando a disposição intema de agire ter controle sobre si mesmo e sua vida.

Não se pode negar que há usuá rios e usuários. Uns são ma is interessados, têm dúvidas e gostariam de saber mais. Outros são mais quietos e talvez, mais acomodados. Mas, independente disso, todos têm direito à educação em saúde de qualidade que seja adequada às suas necessidadese especificidades. 
Cabe ao profissional de saúde, portanto, fomecer os elementos necessá rios para que o usuário consiga vivenciar o processo de adesão com menos dific ulda des ou, quando elas inevitavelmente surgirem, com todo suporte possível. Ao usuário caberá a tarefa de deixar-se ser ajudado, aproveitar e buscar os recursos que lhe são oferecidose, principalmente, cuidar de si.

A concepção que o profissional de saúde tem de que o usuário deve seguir estritamente as suas recomendações, é outro aspecto da interação que pode ser considerado como contribuinte para a sua não-adesão a o RT.

Além de levá-lo a rotular o usuário como teimoso / rebelde, essa concepção impede que o profissional de saúde volte seu foco para o usuário ao invés de para a adesão. Essa acepção também não permite que ele veja o usuário como ser humano que nesse processo de convivência com seu problema de saúde tem falhas como qualquer outra pessoa, em quaisquer outras situações. Ademais, elimina a possibilidade de que a administração do RT pelo usuário à sua maneira seja vista pelo profissional como um processo no qual a adesão está ocorrendo, mas em termose formas pessoaise, prova velmente, com a lguns problemas.

O profissional de saúde poderá contribuir para o melhoramento da adesão se repensar a sua forma de conceber o RTe a adesão. Ao focalizar-se no usuário, o profissional poderá ver que ele está tentando aderir, mas não está conseguindo por motivos que uma boa avaliação os traria à tona. Uma avaliação que, segundo Bakker, Kastermans e Dassen (1995), não é reservada apenas para o profissional, mastambém para a pessoa envolvida.

Neste sentido, o foco das intervenções do profissional também iria mudar, concentrando-se não mais na adesão, mas no usuário e no seu processo de aderir, entendendo que as barreiras e dificuldades variam de pessoa para pessoa; que há microprocessos que se desenvolvem diferentemente em cada indivíduo [p. ex.: o cognitivo] e que é necessário dar um suporte adequado a cada necessidade encontrada.

Em vez de condenar a "transgressão" do usuário (grifo nosso), o profissional poderia aproveitar as situações descritas por ele como oportunidades para trabalhar com ele os aspectos subjacentes ao problema da não-adesão como suas dificuldades, facilidades, barreiras, possibilidades, disposição e aptidões. Segundo Ryn e Heaney (1997), a relação de ajuda efetiva ocorre se o profissional facilita o 
progresso do cliente em direção a metas de promoção da saúde sem criar efeitos negativos.

Como constatamos nos resultados deste estudo, a maioria dos profissiona is de saúde fica sensibilizada quando percebe que a vivência do usuário com a HA e com o seguimento do RTé permeada de dificuldades. Num primeiro momento, essa sensibilidade pode parecer uma atitude empática do profissional de saúde.

Entretanto, examinando os resultados à luz do conceito de empatia de Rogers (1997), tal atitude não é o que parece ser. Segundo o autor, ser empático é compreender o outro, sua situação, seus sentimentos e pensamentos, da foma como ele os vê e aceitar como ele os aceita. É entrar no universo do outro de tal forma que se perca o desejo de julgá-lo ou avaliá-lo, ou esmagar as significações que lhe são preciosas; é a preender não a penas as signific ações de sua experiência que são evidentes, mas também as que são só implícitas.

O profissional de saúde, embora compreenda o usuário e sua situação de dificuldade diante da adesão ao RT, não parece fazê-lo de foma empática, mas apenas simpática. Sua compreensão não se baseia nas percepções o outro, mas nas suas. Além disso, avalia-o e julga-o o tempo todo, fazendo suposições sem ouvilo e rotulando-o, deixando de lado as signific ações dele para dar lugar à s suas.

O profissional julga as ações e motivações do usuário tendo como referência as suas, ou seja, julga pela visão de que o usuário deve estar pronto a aderir a partir do momento em que ele determina. Mesmo que ele perceba as dificuldades do usuário e até tenha uma simpatia por ele, o foco ainda é a adesão, pois na interação, o que ele vê não é uma pessoa com dificuldades para aderir, mas uma a desão que não é alcançada porcausa das dificuldades do usuário.

Neste sentido, portanto, o usuário está sendo visto de uma forma inadequada e esse é outro aspecto da interação dele com o profissional de saúde que pode estar contribuindo para a não-adesão ao RT. Isso leva à necessidade de o profissional de saúde vê-lo de uma nova maneira. Além de simpática, também empática.

Esta pesquisa nos permitiu concluir também que a ação do usuário de administrar o RT à sua maneira é outro aspecto relevante na contribuição que a 
interação entre o profissional de saúde e o usuário pode ter para a não-adesão desse último ao RT.

Como foi visto, nos resulta dos deste estudo o usuário na interação tem papel inexpressivo, em grande parte, devido ao monopólio do profissional sobre as ações desenvolvidas neste contexto sob um paradigma de atuação centrado no profissional de saúde e suasidéias, perspectivas e concepções.

Revelaram, contudo, uma pessoa que "está" apática, passiva, inerte, mas que não "é" desse jeito (grifos nosso). Dentro e fora da interação, o usuário mostrase com suas perspectivas, concepções, razões, atitudes e comportamentos. Mostra que quando se depara com a realidade do regime terapêutico e todas as suas implic ações, ele desenvolve estratégias próprias de enfrentamento da doença e do tratamento.

Estas estratégias não coincidem com o que o profissional de saúde prescreveu e pensa que tem que ser realizado. Desprovido de uma percepção de adesão mais voltada para o usuário e seu processo de adesão, na maioria das vezes, o profissional de saúde entende a maneira do usuário de administrar o RT como um comportamento desviante e uma forma de frustrar sua linha de ação.

Aos olhos do profissional, o usuário que não adere ao RT é teimoso, rebelde, recalcitrante, não segue as suas recomendações como determinadas e não acredita nas coisas que lhe diz. Mesmo que entenda que o usuário tenha dificuldades para aderir, ainda assim, é a adesão que não está acontecendo, é o sucesso do tratamento que não está sendo alcançado. Por causa disso, o usuário, em certo sentido, é tido como culpado e, de certa forma, passa a ser discriminado.

Acreditamos que, se o foco do profissional de saúde se dirigisse mais para a pessoa que está tratando/cuidando, ele se aperceberia de algumas indicações que o usuá rio pode estar lhe fazendo a o administraro RTà sua maneira.

Perceberia que essa maneira do usuário agir pode ser sua forma de apresentar resistência às deteminações do profissional de saúde, tentando presenar a sua autonomia. Resistência que não é calculada ou prevista estrategic amente, mas que se constitui a penas em uma reação defensiva contra a invasão ou desrespeito à sua a utonomia (MARTNS, 2004).

O usuário pode estar indicando também que encontrou uma forma de exercer algum controle sobre sua saúde e sua vida, já que, no espaço da interação, esse controle está nas mãos do profissional de saúde. Na pesquisa de 
Thome, Paterson e Russell (2003), a sautoras descobriram que o processo de tomada de decisão de pessoas com problemas crônicos de saúde refletia o resultado de uma decisão consciente de ganhar controle do manejo de suas doenças e esforç os subseqüentes de assumir esse controle. De acordo com os partic ipantes da pesquisa, manter controle significava sercapaz de mediar os efeitos da doença de tal forma que eles pudessem viver suas vidas o ma is noma Imente possível.

Como foi visto nesta pesquisa, o usuário acredita que o RT é benéfic o a ele e por isso considera que deva seguí-lo. Apesar disso, afima que é duro e penoso para ser seguido à risca como o profissional muitas vezes quer que ele siga. Segundo Fogarty (1997), é evidente que o crescente número de prescrições e proibições aumenta a probabilidade da pessoa se sentir afetada em sua liberdade.

Desta forma, o usuário conforma o RT ao seu funcionamento social e qua ndo isso conflita com seu bem-estar individual, ele se permite alguma indulgência a fim de minimizar o impacto das estritas nomas e regras a ele impingidas. Gonçalves (1998), a o investigar os motivos que levaram pacientes tuberculosos a abandonar seu tratamento, constatou que para eles, aderir ao RT consistia em tomar os medicamentos da melhor maneira possível e isso incluía deixar de tomar o medicamento da forma prescrita pelo médico na intenção de amenizar os efeitos colaterais.

Isso parece indicar que para o usuário, mesmo convencido da necessidade de obedecer às determinações do profissional para ter melhor condição de saúde, ainda é mais forte a necessidade de relativizar a prescrição, encontrando formas de seguir o RT sem que isso seja penoso.

Outra possível indic ação do usuá rio ao profissional de saúde ao administrar o RT à sua maneira é a de que ele pode não estar sabendo lidar com essa situação de doença e tratamento, numa demonstração de que lhe falta ou são insuficientes - conhecimento, as capacidades e habilidades necessárias. Silva, Schenkel e Mengue (2000), ao investigarem o conhecimento de pacientes ambulatoriais relativo aos medicamentos prescritos, descobriram que a maior parte apresentava um nível de informação regular, suficiente para a administração conveniente do medicamento, porém com possibilidade de ocorrência de eventos que poderiam pôr em risco tanto a efetividade do tratamento, como a dificuldade em adequar os horários de administração dos medicamentos à rotina diária de atividades. 
Encontraram, ainda, pequena parcela de pacientes que não tinham o conhecimento mínimo necessário para a administração segura do medicamento.

Conviver com a HA envolve muitos aspectos de sua vida e administrar horário e posologia de medicamentos, tipo de dieta, equilíbrio entre atividade e descanso, monitoramento da PA, aprendizado de altemativas, entre outras ações, são tarefas dinâmicas, complexase, a o mesmo tempo, desafiadoras.

Ao administrar o RT à sua maneira, o usuá rio pode, ainda, estar apontando para o fato de que ele e o profissional de saúde entendem de forma diferente o seguimento do RT. Como visto anteriomente, o profissional considera que o RT deve ser seguido à risca [pois tem como base os padrões de comportamento préestabelecidos nos documentos oficiais]. O usuário parece considerar que algumas falhas não se constituem em prejuízo ao tratamento. Foi o que Gonçalves (1998) descobriu no seu estudo com tuberculosos. A noção de prejuízo a o tratamento por não tomar a medicação como prescrita não existia para a maioria dos informantes - como o tratamento é longo, passar uns dias sem tomaro medicamento não altera os resultados em relação ao processo de cura.

O RT ao mesmo tempo em que é concreto, ou seja, são medidas cientific amente consolidadas, toma-se de certa forma abstrato quando aplicado à vida do usuário. Isto porque o sentido que asmedidas têm para ele, não é o mesmo para o profissional - aquele que o prescreveu. O RT é algo definitivamente fora do contexto de vida da pessoa [mesmo que alguns itens já façam parte de seu cotidiano, não têm o mesmo propósito], e por isso, não é concreto. Durante algum tempo, talvez muito tempo, ele será abstrato até que, num processo próprio, ele se tomará concreto.

Ao seguir o RT à sua maneira, o usuário está transmitindo ao profissional de saúde sua forma de pensar e agir, sua maneira de ver e conceber o RT e seu seguimento, demonstrando que não reconhece e, muitas vezes, não aceita os argumentos que Ihe são apresentados. De acordo com Santos (2000, p. 15-6), a interpretação e a reinterpretação do lugare do papel do profissional no tratamento e na cura de sua doença são sedimentados pelo cliente no decorrer de consultas sucessivas. Nelas, ele afere sua situação e as evoluções esperadas. "Ele lê, absorve, analisa, interpreta e, por fim, reage de acordo com sua formação, com sua habilidade ou aptidão de ver o mundo. Ele decide, então, segundo as categorias de que dispõe, se continuará ou não um deteminado tratamento". 
O usuário, ao administrar o RT à sua maneira, pode estar indicando que a interação entre ele e o profissional de saúde não está sendo adequada. Segundo Hasford (1992), a adesão parcial pode tomar-se mais freqüente quando, entre outras coisas, há uma pobre relação entre o paciente e o profissional.

Tais indicações demonstram que o usuá rio está com problemas na interação e fora dela e que tais problemas se refletem no seu processo de adesão ao RT. São problemas que não dizem respeito apenas à sua doença ou ao seu corpo. Têm a ver também com outras dimensões que fazem parte dele e de seu processo de vida e saúde. As razões que levam uma pessoa a seguir ou desprezar as recomendações terapêuticas indicadas por profissionais, trazem à tona o contexto no qual ele está inserido e sua integralidade como ser humano (STUCHI, 1999).

A complexidade do problema da não-adesão ao RT reside principalmente no fato de que há muita subjetividade envolvida. É preciso, então, que o profissional de saúde comece a mudar o seu foco da doença, do RT e da adesão, para o usuário como uma pessoa, como um sujeito que vivencia a doença, o RT e a adesão.

É necessário que o profissional comece também a mudar o modelo de sua atuação autoritária para um modelo compartilhado, mais voltado para a pessoa que ele assiste. Desta forma, humaniza sua relação, produzindo o equilíbrio necessário ao processo terapêutico. Segundo De Valck et al. (2001), esse é um modelo de atuação que é caracterizado por uma relação mais igualitária entre o profissional e o paciente e no qual é conferido um peso equilibrado às idéias, sentimentose valores de ambos.

Essa proposta é caracteriza da também por uma perspectiva biopsicosocial e cultural a respeito do paciente e seu problema de saúde; por um entendimento tanto do paciente quanto do profissional de saúde como pessoas cujas subjetividades devem ser consideradas, como suas necessidades individuais, expectativas, desejos de participação e envolvimento; por conceber o poder e a responsabilidade na interação como compartilhados; por ter sensibilidade pelas necessidades de informação do paciente, bem como pelas respostas apropriadas a elas; por valorizar as tomadas de decisões compartilhadas, o desenvolvimento de metas terapêuticas comuns e a melhora da relação entre o profissional e o paciente (MEAD; BOWER, 2002; DULMEN, 2003). 
Bensing et al. (2000) dizem que essa mudança de paradigma vem acontecendo gradualmente na área da saúde, mas ao mesmo tempo não tem sido fácil, pois implica em troca de poder entre o profissional e o paciente, a to que não é feito voluntariamente pelo primeiro por estar acostumado a exercê-lo. Ainda assim, de acordo com os autores, muitos profissionais de saúde sinceramente têm pensado que uma atuação mais voltada para o paciente é um requisito para que a qualidade do cuidado seja boa.

Entretanto, não basta que o profissional de saúde esteja motivado para essa nova experiência. De acordo com Kjellgren et al. (1995), é importante que ele enfrente suas barreiras emocionais, educacionais e comportamentais para estar capacitado a encorajaras mudanças de comportamento do paciente.

Da mesma forma, é preciso que o govemo e os serviços de saúde, fazendo parceria com instituições de ensino, se reestruturem e comecem por privilegiar a qualidade ao invés da quantidade, e passem a dar especial atenção e investir na capacitação e treinamento dos profissionais de saúde no sentido de incorporarem ao modelo já existente esse novo modelo de atenção que integra o usuário no cuidado de saúde, que prioriza a troca de informações, a discussão aberta e completa das opções de ações, que assegura o entendimento e a compreensão do usuário e que dá suporte às decisões tomadas.

Para tal, é necessário que nessas capacitações e treinamentos, sejam trazid os os conhec imentos de outras disciplinas como filoso fia, soc iologia, psic ologia e antropologia, bem como conhecimentos aprofundados sobre comunicação e relacionamento interpessoal, que permitam ao profissional de saúde compreender os referencia is nos qua is estão pauta dos seus modos de pensar e a gir, bem como os do usuário, trazendo elementos para a reflexão da sua prática e oportunidades para transfomá-la. Além disso, que ampliem as capacidades e habilidades do profissional de saúde para abordaro usuário e tome-o a pto a lidarcom as situações de saúde/doença vivenciadas entre ele e o usuário no dia-a-dia.

Também é preciso que seja propiciado ao profissional de saúde acesso rápido e atualizado às fontes científicas por meio de computadores e rede de intemet, bem como treinamento em acesso a base de dados.

Da mesma forma, pela diversidade dos elementos que concorrem para que o manejo da HA e a atenção à saúde do hipertenso sejam tão complexos, é 
essencial que a questão da adesão ao RT e a educação do usuário seja tratada com uma abordagem multiprofissional.

Entretanto, é necessário que haja mudanças. Conforme Silva et al (2002) afimam, a estruturação do trabalho multiprofissional nos serviços de saúde não tem garantido respostas adequadas, pois as práticas dos diferentes profissiona is são freqüentemente isoladas e muitas vezes concorrentes, mostrando que há dificuldade de interação entre suas competências técnicas. A forma como o trabalho em equipe é concebido pelos profissionais de saúde desta pesquisa - uma distribuição de tarefas - concorre para que se reproduza a situação acima mencionada pelos autores, mostrando que é preciso que essas falhas sejam reconhecidas e novas fomas de trabalho conjunto e compartilhado sejam implementadas.

É necessário um trabalho multidisciplinar no qual todos os profissiona is que lidam com pessoas hipertensas - médicos, enfemeiros, técnicos e auxiliares de enfemagem, nutric ionistas, psic ólogos, assistentes socia is, professores de educa ção física, farma cêuticos, funcionários administrativos e agentes comunitá rios de saúde (Diretrizes Brasileiras de Hipertensão Arterial, IV, 2002) - trabalhem de forma interligada, despendendo a mesma energia e com objetivos mútuos, considerando a pessoa do usuário, sua subjetividade e diversas necessidades, cada um dando profundidade à sua área de domínio profissional. Segundo J ardim (2001, p. 66),

\footnotetext{
[...] há necessidade de que todos os participantes do processo educativo se posicionem de maneira receptiva, sem atitudes que denotem falta de compromisso, buscando uma comunicação cada vez mais próxima e assimilando a cada encontro as necessidades dos pacientes como cidadãos.
}

Sendo realizado dessa forma, o trabalho multiprofissional terá melhores resultados, pois como Hammond, Bandak e Williams (1999) afimam, estudos têm sugerido que o trabalho compartilhado entre os profissionais de saúde influencia positivamente os resultados da assistência, a contenção dos custos e a satisfação profissional.

Neste sentido, é necessá rio que a enfermeira assuma seu papel na equipe e tome-se visível, pois, como foi visto, na maioria das vezes não tem tido um papel significativo no tratamento do hipertenso. Desempenha ações menores e que são 
mera reprodução das ações médicas e com o agravante de que não são reconhecidas.

À enfermeira falta a capacidade de percebero espaço vazio que está à sua frente. Espaço de demonstração de acolhimento ao usuário - escuta com propósito, diálogo, respeito, conforto e confiança mútua. De acordo com Negrini e Rodrigues (2000), a assistência de enfermagem prestada por meio do relacionamento interpessoal, caracterizada por atitudes de ouvir, compreender, tocar, esclarecer, orientar ou a penaspermanecer ao lado do paciente, fala a favor de um importante espaço profissional.

Da mesma forma, é importante que a enfermeira perceba que há espaço para demonstração de competência técnica por meio da apropriação de teorias e abordagens que crescentemente vêm surgindo no campo da saúde. Também através de uma avaliação profunda e elaborada da saúde do usuáno que inclua a perspectiva dele, pela realização de diagnósticos de enfermagem, pelo estabelecimento de metas e objetivos para o cuidado, pela avaliação dos resultados e pela prestação de cuidados embasados em uma sólida base científica, principalmente voltados para a educação em saúde.

Este estudo revelou que não somente a interação entre o profissional de saúde e o usuário pode contribuir para a não-adesão do usuánio ao RT. Os relatos dos participantes da pesquisa evidenciaram o que a literatura vem apontando há muito tempo. Diversos fatores relacionados aos serviços de saúde e ao SUS também dificultam a adesão do usuário ao RT, como a falta e distribuição intermitente de medic ação, máscondições de trabalho dos profissiona is, entre outros.

São problemas que necessitam uma intervenção mais ampla com o envolvimento dos govemos das três esferas do poder público, como também a formulação e execução de polític as socia is e públic as que melhorem as cond ições de trabalho dos profissionais de saúde, a qualidade de atendimento nas unidades de saúde, a qualificação dos profissionais para a educação em saúde, as condições de saúde e vida da população atendida, entre outros.

Mas embora isso seja necessário, há que se considerar também que muitas vezes o usuário não desempenha seu papel de cidadão na interação com o serviço de saúde deixando de reivindicar seus direitos e assumindo seus deveres. Neste sentido, Traverso-Yépez e Morais (2004) consideram que isto ocorre porque 
muitos usuários deixam de acreditar na sua capacidade de transfomar a realidade por se perceberem destituídos de poder, passando assim a depositar tal responsabilidade nas mãos de outros segmentos que eles acreditam estarem mais aptos para tal façanha.

Cabe, então, aos profissionais de saúde bem como aos serviços e outras instâncias trabalharem no sentido de ajudá-lo a se apoderar de seus direitos e deveres e assumir de vez o seu papel de cidadão dentro e fora da interação. "A expressão das insatisfações e da indignação do cidadão será a contrapartida de uma participação mais ativa e consciente por parte do cliente" (SO AR FILHO, 1998, p. 37).

Ressaltamos ainda que na atenção à saúde do hipertenso, com o propósito de melhorar a sua adesão a o RT, é fundamental que haja mutualidade. Temos que entender que nesse processo, dependemos uns dos outros. O usuário precisa dos profissionais de saúde, assim como de sua família, do serviço e do sistema de saúde para aderir e beneficiar-se com o RT. Da mesma forma, precisamos do usuário que, aderindo, dará sentido e propulsão ao nosso trabalho. A família precisa dele para manter sua estabilidade e saúde, bem como o serviço e o sistema de saúde para manter sua credibilidade.

Se quisemos modificar nossa maneira de agir no tocante às pessoas que cuidamos/tratamos e em relação a o problema da não-adesão, temos que deixar de apenas pensar em formas de melhorar a interação e o seguimento do RT, e partir para a prática acreditando que mesmo ações pequenas, aparentemente insignific antes, podem provocargrandes efeitos não somente no usuário, no serviço e no sistema de saúde, como também em nós. Nosso modo de pensar, aquilo em que acreditamos, é estimulado pelos nossos atos. Agindo, fortalecemos as idéias que estão portrás de nossas ações. 


\section{PARIE 6 - CONSIDERAÇÕES FNAIS}

Os resultados deste estudo fomecem várias implicações para a assistência, o ensino e a pesquisa e algumas delas serão aqui levantadas.

A compreensão de aspectos da interação entre o profissional de saúde e o usuário hipertenso que contribuem para a não-adesão desse último ao RT pode ajudar enfemeiros, médicos e outros profissiona is da área da saúde a perceberem a magnitude da importância dessa interação para a adesão não somente de clientes hipertensos ao RT, mas de todos aqueles que tenham problemas crônicos de saúde.

Pode contribuir também para que esses profissionais de saúde repensem a maneira de lidar com o cliente e com o problema da não-adesão no cotidiano da sua prática, melhorando a adesão dos clientes que assistem.

Através do estabelecimento de parcenias, docentes e profissionais da assistência podem desenvolver educação em saúde aos clientes, utilizando-se de modelose a bordagens que objetivem ajudá-los a melhorar a adesão ao RT. Podem também implementar outras formas de lidar com o problema da não-adesão, como o trabalho em grupos, que favorece a participação dos indivíduos e promove o compartilhamento de experiências.

Devido ao fato de a interação entre o profissional de saúde e o usuário hipertenso não ter sido investigada também por meio da observação direta da pesquisadora, consideramos que estudos futuros poderão ser realizados de tal forma que outros aspectos da interação possam ser investigados, como a estrutura dos serviços de atendimento ao hipertenso, o comportamento dos profissionais de saúde e dos clientes, bem como a freqüência, o tempo e a duração da interação.

Temos em conta que outras questões de pesquisa precisam ser exploradas, ta is como: qua is os a spectos da interação entre o profissional de saúde e o cliente que favorecem a adesão ao RT? Quais motivações o cliente que adere ao RT tem para seguí-lo?

É igualmente importante que sejam feitos estudos de avaliação de projetos que implementem a educação em saúde para clientes hipertensos ou com outros problemas crônic os de saúde. 
Por fim, enfatizamos que os achados deste estudo se relacionam à população e amostra estudadas, bem como ao contexto escolhido. Outros resultados poderão ser encontrados com pesquisas adicionais desenvolvidas em locais e com sujeitos diferentes. Ainda, o uso de referenciais teóricos e metodológicos distintos poderá contribuir de maneira semelhante ou diversa para a compreensão da problemática em questão. 


\section{REERẾNCIAS*}

ARAÚJ O, T. L.; BATISTA, C. M. S. Déficit do conhecimento em portadores de hipertensão arterial. In: GURG EL, A. H.; COSTA, L. B.; VIEIRA, M. D. C. M. O cuidado em saúde. Forta leza: UFC, 2000. pt 3, p. 149-157.

BAKKER, R. H.; KASTERMANS, M. C.; DSSEN, T. W. N. An a nalysis of the nursing diagnosis ineffective management of therapeutic regimen compared to noncompliance and Orem's self-care deficit theory of nursing. Nurs Diagn, Philadelphia, v. 6, n. 4, Oct.Dec. 1995.

BALARD, K. Understanding risk: women's perceived risk of menopause-related disease and the value they place on preventive hormone replacement therapy. Fam Pract, Oxford, v. 19, n. 6, p. 591-5, Dec. 2002.

BARBOSA, M, A.; MEDEIROS, M.; PRADO, M. A.; BACHION, M. M.; BRASIL, V. V. Reflexões sobre o trabalho do enfermeiro em saúde coletiva. Revista Eletrônic a de Enfermagem, v. 6, n. 1, p. 9-15, 2004. Disponível em: বhttp:// www.fen.ufg.br > Acesso em: 10 ago. 2004.

BARRETO, M. L.; CARMO, E. H. Situação de saúde da população brasileira: tendências históricas, determinantes e implicações para as políticas de saúde. Informe Epidemiológico do SUS. Brasilia, ano 3, n. 3/4, p. 7-34, jul. -dez. 1994.

BASTOS, D. S. Cuidando de pessoas portadoras de hipertensão: contribuindo para a superação dos déficits de autocuidado. 2002. 144 f. Dissertação (Mestrado) Universidade Federal de Santa Catarina, Floria nópolis, 2002.

BASTOS, D. S.; BORENSTEIN, M. S. Identific ando os défic its de autocuidado de clientes hipertensos de um centro municipal de saúde. Texto Contexto Enferm, Florianópolis, v. 13, n. 1, p. 92-9, jan.-mar. 2004.

BENSING , J; VERHAAK, P. F. M.; DULMEN, A. M. van; VISSER, A. Communication: the royal pathway to patient-centered medic ine. Patient Edu Couns., Princeton, v. 39, p. $1-3,2000$.

BERUNG UER, G. Promoção da saúde. In: Questões de vida: ética, ciência e saúde. Salva dor: APCE- Hucitec-Cebes, 1993. cap. 10, p. 149-59.

BITAR, N. Maintaining long-term control of blood pressure: the role of improved compliance. Clin Cardiol, Mahwah, v. 18, p. III-12-III-16, 1995. Supplement 3.

BLACK, J. M.; MATASSARIN-JACOBS, E. Condições crônicas. In: Enfermagem médico-cinúrgica: uma abordagem psicofisiológica. 4. ed. Rio de Janeiro: Guanabara Koogan, 1996. cap. 9, p. 117-133.

\footnotetext{
* De acordo com:

UNIVERSIDADE DE SÃO PAULO. Sistema Integrado de Bibliotecas. Grupo Di Teses. FUNARO, V. M. de O. et al. Diretrizes para apresentação de dissertações e teses da USP: documentos eletrônicos ou impressos. São Paulo: SiBi-USP, 2003. 98 p.
} 
BLOCH, K. V. Fatores de risco cardiovascula res e para o diabetes mellitus. In: LESSA, I. O adulto brasileiro e as doenças da modemidade: epidemiologia das doenças c rônic as não-transmissíveis. São Paulo: Hucitec-Abrasco, 1998. ca p. 3, p. 43-72.

BLUMMER, H. Symbolic interacionism: perspective and method. London: University of Califomia, 1969. 208 p.

BOGDAN, R.; BIKLEN, S. Investigação qualitativa em educação: uma introdução à teoria e aos métodos. Tra dução de Maria J oão Alva rez. Porto: Porto, 1994. 335 p.

BO LTANSKI, L. As classes sociais e o como. 3 ed. Tradução Regina A. Machado: Rio de J aneiro: Graal, 1989. 191 p.

BRASIL. Ministério da Saúde. Secretaria de Políticas de Saúde. Departamento de Ações Programáticas Estratégicas. Nomas técnicas para o programa nacional de educ ação e controle da hipertensão arterial. Brasília, 1988. 88 p.

BRASIL. Ministério da Saúde. Secretaria de Políticas de Saúde. Departamento de Ações Programáticas Estratégicas. Plano de reorganização da atenção à hipertensão arterial e diabetes mellitus. Brasilia: 2001. 102 p. (série C. Projetos, Programase Relatórios; n. 59)

BROOM, D.; WHITTAKER, A. Controlling diabetes, controlling diabetics: moral language in the management of diabetes type 2. Soc Sci Med, Oxford, v. 58, p. 2371-82, 2004.

CADE, N. V. O cotidiano e a adesão a o tra tamento da hipertensão a rterial. Cogitare Enferm, Curitiba, v. 2, n. 2, p. 10-15, jul.-dez. 1997.

. O processo psicossocial faza diferença na compreensão e na educação para a saúde de pessoas com doenças crônicas. Cogitare Enferm, Curitiba, v. 3, n. 1, p. 57 - 60, jan. / jun. 1998.

CAPRARA, A.; FRANCO, A. L. S. A relação paciente-médico: para uma humanização da prática médica. Cad saúde pública, Rio de Janeiro, v. 15, n. 3, p. 647-54, jul.-set. 1999.

CAPRARA, A.; RODRIGUES, J. A relação assimétric a médico-pa ciente: repensa ndo o vínc ulo tera pêutico. Ciênc. saúde coletiva, Rio de J a neiro, v. 9, n. 1, p. 139-46, 2004.

CAR, M. R. A mortalidade cardio-cerebrovascular e os problemas da prática no controle da hipertensão arterial. Rev Esc Enf USP, São Paulo, v. 32, n. 2, p. 140-143, ago. 1998.

CARO, J. J .; SPECKMAN, J. L. Existing treatment strategies: does noncompliance make a difference? J Hypert, London, v. 16, p. S31-S34, 1998. Supplement 7.

CARPENITO, L. J. Diagnósticos de enfemmagem: aplicação à prática clínica. Tradução de Ana Thorrell. 6. ed. Porto Alegre: Artes Médicas, 1997. 812 p.

CASTRO, V. D.; CAR, M. R. O cotidiano da vida de hipertensos: mudanças, restrições e reações. Rev. Esc. Enf. USP, São Paulo, v. 34, n. 2, p. 145-53, jun. 2000. 
CASTRO, R. C. L; TIEIZMANN, M.; SCHÖFFEL, A. C. A influencia dos transtomos psiquiátricos na aderência tera pêutica. Rev. psiquiatr, Rio de J a neiro, v. 25 , n. 1, p. 222-5, jan.-abr. 2003.

CHARON, J. M. Symbolic interacionism: an introduction, an interpretation, an integration. 6 ed. New J ersey: Prentice Hall, 1998. 245p.

. Sociologia. Tra dução La ura Teixeira Motta. São Paulo: Sa ra iva, 2000. 237 p.

CHENITZ, W. C.; SWANSON, J. M. From practice to grounded theory: qualitative research in nursing. Menlo Park: Addison-Wesley, 1986. 257 p.

CLARK, L. T. Improving compliance and increasing control of hypertension: needs of special hypertensive populations. Am Heart J, St. Louis, v. 121, n. 2, pt 2, p. 664-669, Feb. 1991.

CHOBANIAN, A. V.; BAKRIS G. L.; BLACK, H. R.; CUSHMAN, W. C.; GREEN, L. A.; IZZO, J r J. L.; J ONES, D. W.; MATERSON, B. J .; OPARIL, S.; WRIGHT, J r J . T.; ROCCEШA, E. J .; NATIONAL HIGH BLOOD PRESSURE EDUCATION PROGRAM COORDINATING COMMITTEE. The seventh report of the Joint National Committee on Detection, Evaluation and Treatment of High Blood Pressure: the J NC 7 report. JAMA, Chicago, v. 289, n. 19, p. 2560-72, May, 2003.

CONRAD, P. The meaning of medications: a nother look at compliance. Soc Sci Med, Oxford, v. 20, n. 1, p. 29-37, 1985.

CONSENSO BRASILEIRO DE HIPERTENSÃO ARTERIAL, 3.,1998, Campos do Jordão. Relatório... [S.I.]: Sociedade Brasileira de Hipertensão, 1998.

CRESWEШ, J. W. Qualitative inquiry and research design: chosing among five traditions. Thousand Oaks: Sage, 1998. 401p.

DE VALCK, C.; BENSING , J .; BRUYNOOGHE, R.; BATENBURG, V. Cure-oriented versus care-oriented attitudes in medic ine. Patient Edu Couns, Princeton, v. 45, p. 119-26, 2001.

DIREIRIZTS BRASILEIRAS DE HIPERTENSÃO ARTERIAL, 4., 2002, Campos do Jordão. Relatório... [S. L]. Socieda de Bra sileira de Hipertensão, 2002.

DOWEL, J; HUDSON, H. A qualitative study of medication-taking behaviour in primary care. Fam Pract, Oxford, v. 14, n. 5, Great Brita in, 1997.

DRESSLER, W. W.; SANTOS, J. E. dos Social and cultural dimensions of hypertension in Brazil: a review. Cad saúde pública, Rio de Janeiro, v. 16, n. 2, p. 303-315, abr.-jun. 2000.

DULMEN, S. van. Patient centredness. Patient Edu Couns, Princeton, v. 51, p. 195-96, 2003.

DURHAM, R. F. Negotiating activity restriction: a Teoria Fundamentada nos Dados of home management of preterm labor. Qual Health Res, Newbury Park, v. 9, n. 4, p. 493-503, J ul. 1999. 
FERREIRA, J . A saúde em comprimidos: influências soc ioc ultura is na interpreta ção de sintomas e terapias medicamentosas em uma vila de classe popular de Porto Alegre. Saúde debate, Londrina, v. 25, n. 59, p. 67-72, set.-dez. 2001.

FINEMAN, N. The social construction of noncompliance: a stydy of health care and social service providers in everyday practice. Sociol Health Illn, Boston, v. 13, n, 3, p. 355-74, 1991.

FOGARTY, J . S. Reactance theory and patient noncompliance. Soc Sci Med, Oxford, v. 45, n. 8, p. 1277-88, 1997.

FONTANELLA, B. J. B.; TURATO, E. R. Barreiras na relação clínico-paciente em dependentes de substâncias psicoativas procurando tratamento. Rev saúde pública, Sã o Paulo, v. 36, n. 4, p. 439-47, 2002.

FORTES, A. N.; LOPES, M. V. O. Análise dos fatores que interferem no controle da pressão arterial de pessoas acompanhadas numa unidade básica de atenção à saúde da família. Texto Contexto Enferm, Floria nópolis, v. 13, n. 1, p. 26-34, jan.-mar. 2004.

FOSTER, S. B.; KOUSCH, D. Fidelida de ao tratamento nos pacientes hipertensos. Clín Enfermagem Am Norte. Rio de J a neiro, v. 16, n. 2, p. 315-325, jun. 1988.

FRANCIS, C K. Hypertension cardiac disease and compliance in minority patients. Am J Med, New York, v. 91, p. 1A-29S- 1A-36S, J uly 1991. Supplement I A.

FREIRE, P. Pedagogia do oprimido. 17 ed. Rio de J a neiro: Paz e Terra, 1987, 184 p.

FUNDAÇÃO NACIONAL DE SAÚDE. Mortalidade por doenças cardiovasculares. Disponível em: http://www. Funasa.gov.br/sis/polfs/mortalidade_1998.PDF. Acesso em: 25 jun. 2002.

GLASER, B. G.; STRAUSS, A. L The discovery of grounded theory: strategies for qualita tive research. New York: Aldine, 1967. 271 p.

GONÇALVES, H. D. Compo doente: estudo acerca da percepção corporal da tuberculose. In: DUARTE, L. F. D.; LEAL, O. F. (Coord.). Doença, sofrimento, perturbação: perspectives etnográficas. Rio de Janeiro: Fiocruz, 1998. cap. 6, p. 105117.

GONÇALVES, H.; COSTA, J. S. D.; MENEZ⿱一S, A. M. B.; KNAUTH D.; LEAL, O. F. Adesã o à terapêutica da tuberculose em Pelotas, Rio Grande do Sul: na perspectiva do paciente. Cad saúde pública, Rio de J a neiro, v. 15, n. 4, p. 777-87, out.-dez. 1999.

GROPPER, R. C. Cultural basics and chronic illness. Adv Ren Replace Ther, Phila delphia, v. 5, n. 2, p. 128-33, Abr. 1998.

GRUENING ER, U. J . Arterial hypertension: lessons from patient education. Patient Edu Couns, Princeton, v. 26, p. 37-55, 1995.

GUERRA, E. M. D.; ARAÚJ O, T. L. Aderência a o tratamento da hipertensão arterial: comportamentos observados e causas relacionadas. In: DAMASCENO, M. M. C.; ARAÚJ O, T. L.; FERNANDES, A. F. C. Transtomos vitais no fim do século XX: diabetes 
mellitus, distúrbios cardiovasculares, câncer, AIDS, tuberculose e hanseníase. Fortaleza: FCPC, 1999. pt 2, p. 39-46.

HALEIT, C. E.; AUSTIN, L.; CARESS, A.; LUKER, K. A. Community nurses' perceptions of patient 'compliance' in wound care: a discourse analysis. J Adv Nurs, Oxford, v. 32, n. 1, p. 115-23, 2000.

HAMMOND, K.; BANDAK, A.; WIШAMS, M. Nurse, physician, and consumer role responsibility perceived by hea Ith ca re providers. Holist Nurs Pract Frederick, v. 13, n. 2, p. 28-37, 1999.

HASFORD, J. Compliance and the benefit/risk relationship of antihypertensive treatment. J Cardiovas Pham, New York, v. 20, p. S30-S34, 1992. Supplement 6.

HAUG LI, L.; STRAND, E.; FINSET, A. How do patients with meumatic disea se experience their relationship with their doctors? : a qualitative study of expeniences of stress and support in the doctor-patient relationship. Patient Edu Couns, Princeton, v. 52, p. 16974, 2004.

HAYES-BAUTISTA, D. E. Modifying the treatment: patient compliance, patient control and medical care. Soc Sci Med, Oxford, v. 10, p. 233-38, 1976.

HELLSTRÖM, O.; BULUNGTON, J .; KARLSSON, G .; LINDQVIST, P.; MATISSO N, B. Doctors' attitudes to fibromyalgia: a phenomenological study. Scand J Soc Med, Stockholm, v. 26, n. 3, p. 232-7, Sep. 1998.

HEURTIN-ROBERTS, S.; REISIN, E. The relation of culturally influenced lay models of hypertension to compliance with treatment. Am J Publ Health, Washington, v. 5, n. 11, p. 787-92, Nov. 1992.

HULKA, B. S.; CASSEL, J. C., KUPPER, L. L., BURDETIE, J. A. Communication, compliance, and concordance between physicians and patients with prescribed medications. Am J Publ Health, Washington, v. 66, n. 9, p. 847-53, Sep. 1976.

JARDIM, P. C. B. Adesão ao tratamento anti-hipertensivo: modelos de estudo. In: NOBRE, F.; PIERIN, A. M. G.; JUNIOR, D. M. Adesão ao tratamento: o grande desafio da hipertensão. São Paulo: Lemos, 2001. cap. 4, p. 59-68.

J OINT NATIO NAL COMMITIEE ON DETECTION, EVALUATION AND TREATMENT OF HIG H BLO OD PRESSURE. 6., 1997, [S.L.] Relatório... [S.L.], NIH, 1997.

KHALL, S. A.; ELZUBIER, A. G. Drug compliance among hypertensive patients in Tabuk, Saud Arabia. J Hypert, London, v. 15, p. 561-565, 1997.

KIISKINEN, U.; VARTIAINEN, E.; PUSKS, P.; AROMAA, A. Long-term cost and life expectancy consequences of hipertensión. J Hypert, London, v. 16, p. 1103-1112, 1998.

KJ ELLGREN, K. I., AHLNER, J.; SÄLJÖ, R. Taking antihypertensive medication: controlling or co-operating with patients? Inter J Cardiol, Amsterdam, v. 47, p. 257268, 1995. 
KOCHAR, M. S.; WOODS, K. D. Controle da hipertensão para enfermeiras e demais profissionais. 2. ed. São Paulo: Andrei, 1990. 317 p.

KRASILCIC, S. Índices de adesão aos tratamentos medicamentoso e nãomedicamentoso no Brasil e no mundo. In: NOBRE, F.; PIERIN, A. M. G.; JUNIOR, D. M. Adesão ao tratamento: o grande desafio da hipertensão. São Paulo: Lemos, 2001. cap. 3, p. 49-55.

LACROIX, A.; JACQUEMENT, S.; ASSAL, J. Patients' experiences with their disease: leaming from the differences and sharing the common problems. Patient Educ Couns, Princeton, v. 26, p. 301-12, 1995a.

LACROIX, A.; JACQUEMENT, S.; ASSAL, J.; BENROUBI, M. The patients' voice: testimonies from patients suffering from chronic disease. Patient Educ Couns, Princeton, v. 26, p. 293-9, 1995b.

LEITE, S. N.; VASCONCELOS, M. P. C. Adesão à terapêutica medicamentosa: elementos para a discussão de conceitos e pressupostos adotados na literatura. Ciênc. saúde coletiva, Rio de J a neiro, v. 8, n. 3, p. 775-82, 2003.

LESSA, I. Doenças não-transmissíveis. In: ROUQUAYROL, M. Z Epidemiologia e saúde. 4. ed. São Paulo: Medsi, 1994. cap. 9, p. 269-279.

. Epidemiologia da hipertensão arterial. In: O adulto brasileiro e as doenças da modemidade: epidemiologia das doenças crônicas não-transmissíveis. São Paulo: Hucitec-Abra sc o, 1998a. cap. 5, p. 77-96.

. Epidemiologia do tratamento e da adesão ao tratamento da hipertensão arterial e do diabetes mellitus. In: 0 adulto brasileiro e as doenças da modemidade: epidemiologia das doenças crônicas não-transmissíveis. São Paulo: Hucitec-Abrasc 0, 1998b. cap. 13, p. 223-239.

O adulto brasileiro e as doenças da modemidade: epidemiologia das doenças crônic as não-transmissíveis. São Paulo: Hucitec-Abrasco, 1998. 284 p.

Doenças crônicas não-transmissíveis: bases epidemiológicas. In: ROUQUAYROL, M. Z Epidemiologia e saúde. 5. ed. Rio de Janeiro: Medsi, 1999. cap. 129, p. 285-299.

LESSA, I.; MENDO NÇA, G. A. S.; TEIXEIRA, M.T.B. Doenç as crônic as não-tra nsmissíveis no Brasil: dos fatores de risco ao impacto social. Bol Oficina Sanit Panam, Wha shington, DC, v.120, n. 5, p. 389 - 412, 1996.

LTLEJ OHN, S. W. Fundamentos Teóricos da Comunicação. In: Interacionismo simbólico. Rio de J a neiro: Za har, 1982. cap. 3, p. 65 - 73.

LOPES, A. A. Raça e hipertensão a rterial. HiperAtivo, São Paulo, v. 3, n. 3, p. 153-172, jul.-set. 1996.

LUPTON, D. Consumerism, reflexivity and the medical encounter. Soc Sci Med, Oxford, v. 45, n. 3, p. 373-81, 1997. 
MACLEAN, N.; PHIL, B; POUND, P.; WOLFE, C.; RUDD, A. The concept of patient motivation. Stroke, New York, v. 33, p. 444-48, 2002.

MALDONADO, M. T.; CANEШA, P. Recursos de relacionamento para profissionais de saúde: a boa comunicação com clientes e seus familiares em consultórios, a mbulatórios e hospita is. Rio de J aneiro: Reichmann \& Affonso, 2003. 320 p.

MARTIN, D. Informação e comportamento: o exemplo da Aids. Psiq Prat Méd, São Paulo, v. 33, n. 3, p. 101-3, jul.-set. 2000.

MARTINS, A. Biopolítica: o poder médico e a autonomia do paciente em uma nova concepção de saúde. Interface, Botucatu, v. 8, n. 14, p. 21-32, set. 2003- fev. 2004.

MATO GROSSO. Secretaria de Estado de Saúde. Superintendência de Atenção Integral à Saúde. Coordenadoria de Apoio ao Desenvolvimento de Rede de Senviços e Sistemas. Gerência de Programas Especia is. Plano de reorganização da atenção à hipertensão arterial e diabetes mellitus: campanha nacional de detecção de casos suspeitos de hipertensão arterial e promoção de hábitos saudá veis de vida. Cuiabá, 2002. / Mimeografado/

MAY, C. Patient autonomy and the politic s of professional relationships. . J Adv Nurs, Oxford, v. 21, p. 83-7, 1995.

McGRATH, J. M. Physicians' perspectives on communicating prescription drug information. Qual Health Res, Newbury Park, v. 9, n. 6, p. 731-745, Nov. 1999.

MEAD, N.; BOWER, P. Patient-centred consultations and outcomes in primary care: a review of the literature. Patient Edu Couns, Princeton, v. 48, p. 51-6, 2002.

MINAYO, M. C. de S. O desafio do conhecimento: pesquisa qualita tiva em saúde. 2. ed. São Paulo: Hucitec-Abrasc o, 1993. 269 p.

MION JÚNIOR, D.; PIERIN, A. M. G.; GUIMARÃES, A. Tratamento da hipertensão arterial: respostas de médicos brasileiros a um inquérito. Rev Ass Med Brasil, São Paulo, v. 47, n. 3, p. 249-54, 2001.

MISSELBRO OK, D.; ARMSTRONG, D. Thinking a bout risk. Can doctors and patients talk the same language? Fam Pract, Oxford, v. 19, n. 1, p. 1-2, 2002.

MUELA, S. H.; RIBERA, J. M.; MUSHI, A. K.; TAÑNER, M. Medical syncretism with reference to malaria in a Tanzanian community. Soc Sci Med, Oxford, v. 55, p. 40313, 2002.

MUNÕZ, L. A.; PRICE, Y.; GAMBINI, L; STEFANEШ, M. C. Signific ados simbólicos de los pacientes con enfermedades crónicas. Rev. Esc. Enf. USP, São Paulo, v. 37, n. 4, p. 77-84, 2003.

NEG RINI, M. R.; RODRIGUES, A. R. F. Relacionamento terapêutico enfermeiropaciente junto a mulheres mastectomizadas. Mundo saúde, São Paulo, v. 24, n. 4, jul.-ago. 2000. 
OIGMAN, W. Métodos de avaliação da a desão ao tratamento a nti-hipertensivo. In: NOBRE, F.; PIERIN, A. M. G.; J UNIOR, D. M. Adesão ao tratamento: o grande desafio da hipertensão. São Paulo: Lemos, 2001. cap. 2, p. 36-46.

ORTEGA, K. C.; NOBRE, F; MION JÚNIOR, D. Fatores intervenientes na adesão e recomendações práticas para melhoria dos resultados. Adesão ao tratamento: o grande desafio da hipertensão. São Paulo: Lemos, 2001. cap. 7, p. 107-18.

PAVLOVICH-DANIS, S. J . Lifeplan: when prescription blues put your patient in the red.

Clinician News, v. 7, n. 8, p. 8-11, 2003. Disponível em: বhttp: //www.medscape.com/viewartic le/463604_print>. Acesso em: 8 dez. 2003.

PÉRES, D. S.; MAGNA, J. M., VIANA, L. A. Porta dor de hipertensão a rterial: a titudes, crenças, percepções, pensamentos e práticas. Rev saúde ública, São Paulo, v. 37, n. 5, p. 635-42, 2003.

PIERIN, A. M. G. Adesão ao tratamento: conceitos. In: NOBRE, F.; PIERIN, A. M. G.; JUNIOR, D. M. Adesão ao tratamento: o grande desafio da hipertensão. São Paulo: Lemos, 2001. cap. 1, p. 22- 33.

REINERS, A. A. O.; PANIAGO, I. S.; FLECK, L. A.; GOULART, M. S. Conviver com um problema crônico de saúde: seu significado, dificuldades e implicações. Col Enf, Cuiabá, v. 2, n. 2, p. 76-93, jul.-dez., 2002.

ROGERS, C. R. Tomar-se pessoa. Tradução Manuel José do Camo Ferreira e Alva mar Lampa relli. 5. ed. São Paulo: Martins Fontes, 1997.

ROGERS, A. E.; ADDINGTON-HAШ, J. M.; ABERY, A. J .; MCCOY, A. S. M.; BULPITT, C.; COATS, A. J . S.; GIBBS, J. S. R. Knowledge and communic ation diffic ulties for patients with chronic heart failure: qualitative study. BMJ , São Paulo, v. 321, n. 9, p. 605-7, Sep. 2000.

ROMANO, B. W. Aspectos psicológicos do paciente coronariopata portador de hipertensão arterial. HiperAtivo, São Paulo, v. 6, n. 1, p. 57-59, ja n.- mar. 1999.

ROTER, D. The enduring and evolving nature of the patient-physician relationship. Patient Edu Couns, Princ eton, v. 39, p. 5-15, 2000.

RYN, M. van; HEANEY, C. A. Developing effective helping relationships in health education practice. Health Educ Behav, Thousands Oaks, v. 24, n. 6, p. 683-702, Dec . 1997.

SANTOS, J. Q. Adesão a tra tamentos médicos. Psiq Prat Méd. São Paulo, v. 33, n. 1, p. 14-16, jan.-mar. 2000.

SANTOS, S. R.; LACERDA, M. C. N. Fatores de satiffação e insatisfação entre os pacientes assistidos pelo SUS. R. Bras. Enferm., Bra sília, v. 52, n. 1, p. 43-53, jan.-mar. 1999.

SHEA, S. Hypertension control. Am J Publ Health, Washington, v. 84, n. 11, p. 17251727, Nov. 1994. 
SILVA, N. E. K.; OUVEIRA, L. A.; FIG UEIREDO, W. S.; LANDRONI, M. A. S.; WALDMAN, C. C. S.; AYRES, J. R. C. M. Limites do trabalho multiprofissional: estudo de caso dos centros de referência para DST/Aids. Rev saúde pública, São Paulo, v. 36, n. 4, p. 108-16, 2002. Supl.

SILVA, T.; SCHENKEL, E. P.; MENGUE, S. S. Nível de informação a respeito de medicamentos prescritos a pacientes ambulatoriais de hospital universitánio. Cad saúde pública, Rio de J a neiro, v. 16, n. 2, p. 449-55, a br.-jun. 2000.

SMELTZER S. C.; BARE, B. G. Avaliação e assistência aos pacientes com distúrbios vasculares e problemas na circulação periférica. In:

Tratado de

enfermagem médico-cinúrgica. 7. ed. Rio de Janeiro: Guanabara Koogan, 1994. cap. 31, p. 633-668.

SOAR FILHO, E. J . Intera ção médic o-cliente. Rev Ass Med Brasil, São Paulo, v. 44, n. 1, p. 35-42, 1998.

STEPHENSON, B. J .; ROWE B. H.; HAYNES, R. B.; MACHARIA, W. M.; LEON, G. Is this patient taking the treatments prescribed? JAMA, Chicago, v. 269, n. 21, p. 2779-81, 1993.

STEVENSO N, D. R. Blood pressure and age in cross-cultural perspective. Human Biol, Baltimore, v. 71, n. 4, p. 529-551, 1999.

STIMSON, G. V. Obeying doctor's orders: a view from the other side. Soc Sci Med, Oxford, v. 8, p.97-104, 1974.

STOCKWELL, D. H.; MADHAVAN, S.; COHEN, H.; GIBSON, G.; ALDERMAN, M. H. The determinants of hypertension awareness, treatment and control in insured population. Am J Public Health, Washington, v. 84, p. 1768-74, 1994.

STRAUSS, A. L. Qualitative analysis for social scientists. New York: Cambridge University Press, 1987. 319 p.

STRAUSS, A. L.; CORBIN, J. Basics of qualitative research: grounded theory procedures and techniques. Califomia: Sage Publications, 1990. 271 p.

STRELEC, M. A. A. M.; PIERIN A. M. G.; MION JÚNIOR, D. The influence of patient's consciousness regarding high blood pressure and patient's attitude in face of disea se controlling medic ine intake. Arq Bras Cardiol, São Paulo, v. 81, n. 4, p. 34954, 2003.

STUCHI, R. A. G. Crenças dos portadores de doença coronariana sobre os comportamentos de risco. 1999. 156 f. Dissertação (Mestrado) - Escola de Enfermagem de Ribeirão Preto, Universida de de São Paulo, Ribeirão Preto, 1999.

THORNE, S.; PATERSON, B.; RUSSELL, C. The structure of everyday self-care decision making in chronic illness. Qual Health Res, Newbury Park, v. 13, n. 10, p. 1337-52, Dec. 2003.

TRAVERSO-YÉPEZ, M.; MORAIS, N. A. Reivindicando a subjetivida de dos usuários da rede básica de saúde: para uma humanização do atendimento. Cad saúde pública, Rio de J a neiro, v. 20, n. 1, p. 80-8, jan.-fev. 2004. 
TROSTLE, J. A. Medic al compliance as an ideology. Soc Sci Med, Oxford, v. 27, n. 12, p.1299-1308, 1988.

WALTER, F. M.; BRITIEN N. Patients' understanding of risk: a qualitative study of decision-making about the menopause and homone replacement therapy in general practice. Fam Pract Oxford, v. 19, n. 6, p. 579-86, Dec. 2002.

WENDHAUSEN, A.; SAUPE, R. Concepções de educação em saúde e a estratégia de saúde da família. Texto Contexto Enferm, Floria nópolis, v. 12, n. 1, p. 17-25, jan.-mar. 2003.

WILSO N, R. P.; FREEMAN, A.; KAZO LA, M. J .; ANDREWS, T. C., BERRY, L.; VAETH, P. A. C.; VICTOR, R. G. Lay beliefs about high blood pressure in a low-to-middle-income urban African-american community: an opportunity for improving hypertension control. Am J Med, New York, v. 112, p. 26-30, 2002.

WISSOW, L. S. Communication and malpractice claims: where are we now? Patient Edu Couns, Princ eton, v. 52, p. 3-5, 2004.

WORLD BANK. Latin América and the Caribbean Region. Adult health in Brazil: adjusting to new challenges. Washington, DC, 1989. 66p.

WORLD HEALTH ORGANIZATION. Intemational Society of Hypertension guidelines for the management of hypertension. J Hypert, London, v. 17, p. 151-183, 1999. 


\section{APÊNDICE A - ROTIERO DE ENTREVISTA COM O PRORSSIONALDE SAÚDE}

Nome, idade, sexo, profissão, especialidade, anos de experiência profissional, tempo de atuação profissional com hipertensos.

Estou interessada na sua interação com 0 usuário hipertenso, assim, gostaria que você me falasse sobre 0 seguinte:

1. No contexto da assistência à saúde do hipertenso que você presta rotineiramente, como tem sido a sua interação com o usuário?
a. O que você costuma dizer a ele?
b. Que tipo de tratamento (regime terapêutico) você costuma prescrever (medidas farmacológicas e não farmacológicas)?
c. Você costuma enfatizar uma ou outra? Qual? Por quê?
d. Você instrui o usuário sobre o tratamento (RT)? Como?
e. Como você considera o RT prescrito? São pedidos, ordens, conselhos?
f. Você costuma alertar o usuário sobre as complicações da HÁ? Por quê? Como você faz isso? Quando?
g. O que ele costuma dizer a você durante a consulta ou atendimento?
h. Para você, como é um bom atendimento?

2. Como você percebe a situação do usuário de ser hipertenso e ter que seguir um regime terapêutico?

3. Como você vê o usuário que segue o regime terapêutico? Como você o definiria?

a. O que você sente/pensa quando isso acontece?

4. Como você vê o cliente que não segue o regime terapêutico? Como você o definiria?

a. O que você sente/pensa quando isso acontece?

5. Quando é que você considera que o usuário não está aderindo ao RT?

6. Quando o usuário revela que não está seguindo em parte ou no todo o RT o que você faz?

7. Existe algum tipo de cliente que você considera mais fácil ou mais difícil de lidar?

8. De quem é a responsabilidade pela adesão do usuário ao RT?

9. De quem é a responsabilidade quando o usuário não adere ao RT?

10. Na literatura, um dos fatores que contribui para o cliente não seguir o RT é a relação profissional de saúde/cliente. Você concorda com isso? Por quê? 


\section{APÊNDICE B - ROTEIRO DE ENIREVISTA COM O USUÁRIO HIPERIENSO}

Nome, idade, sexo, estado civil, ocupação, grau de escolaridade, há quanto tempo sabe ser hipertenso e tempo de tratamento.

1. Qual o tratamento para hipertensão (regime terapêutico) que foi prescrito para você?

2. Como você considera esse tratamento? Pedidos, conselhos, ordens?

3. Como tem sido sua convivência com a HA e o tratamento?

a. O que você acha de ter que seguir o tratamento (RT)?

b.Você segue o que o profissional lhe pede? Por quê?

4. Fale sobre sua interação com o profissional de saúde que 0 atende (não só aquele pelo qual está sendo atendido atualmente):

a. Como tem sido a sua interação com ele?

b. O que você costuma dizer a ele?

c. O que ele costuma dizer a você?

d. O profissional faz perguntas? Que tipo de perguntas?

e. Na sua opinião, por que ele faz essas perguntas?

f. Você consegue respondê-las? Em que caso é difícil?

g. O profissional faz orientações (sobre a doença e o RT, sobre o que se espera que você faça os objetivos a serem alcançados com o RT, o que o profissional fará por você, as expectativas de ambas as partes, ...)?

h. Que tipo de orientações?

i. Na sua opinião, por que ele faz essas orientações?

j. Você consegue entendê-las? Em que caso é difícil?

k. Você faz perguntas?

I. Ele costuma responder?

m. Ele diz tudo o que você gostaria de saber?

n. Você concorda com as coisas que são ditas para você na interação? Com o que você concorda? Se não concorda, com o que você não concorda? 


\section{APÊNDICE C - \\ FORMULÁRIO DE TERMO DE CONSENTIMENTO LIVRE E ESCLARECIDO}

(para o profissional) (para o usuário) ${ }^{1}$

Projeto: "Contribuição da interação entre o profissional de saúde e o cliente para a adesão ao regime terapêutico".

Pesquisador: Annelita Almeida Oliveira Reiners

Objetivo principal: Compreender a interação entre o profissional de saúde e o cliente hipertenso e sua contribuição para a adesão ao tratamento.

Procedimentos: Entrevista e possível observação

Possíveis riscos e desconfortos: Nenhum risco de vida e desconforto inicial mínimo.

Benefícios previstos: Nenhum benefício material.

Eu.

$R G$ :

fui

informado dos objetivos, procedimentos, riscos e benefícios desta pesquisa, descritos acima.

Entendo que terei garantia de confidencialidade, ou seja, que apenas dados consolidados serão divulgados e ninguém, além do pesquisador, terá acesso aos nomes dos participantes desta pesquisa. Entendo também, que tenho direito a receber informações adicionais sobre o estudo a qualquer momento, mantendo contato com 0 pesquisador. Fui informado ainda, que a minha participação é voluntária e que nenhum dano, risco ou ônus ocorrerá sobre a minha pessoa. Se eu preferir não participar ou deixar de participar deste estudo em qualquer momento, isso NÃO me acarretará qualquer tipo de penalidade.

Compreendendo tudo o que me foi explicado sobre o estudo a que se refere este documento, concordo em participar do mesmo.

Assinatura do participante:

Assinatura do pesquisador:

Em caso de necessidade contate o pesquisador no endereço $x x x$, telefone $x x x$, e-mail $x x x$.

\footnotetext{
${ }^{1} \mathrm{O}$ formulário de consentimento do usuário foi semelhante a este, exceto que nele o vocabulário foi simplificado para que o participante tivesse uma melhor compreensão.
} 
ANEXO A - COMPROVANTE DE APROVAÇÃO DA PESQUISA PEIO COMTÊ DE ÉICCA EM PESQUISA 